\title{
The Volk of New Jersey? State Identity, Distinctiveness, and Political Culture in the American Federal System
}

\author{
Ernest A. Young*
}

\begin{abstract}
The legal literature on federalism has long taken for granted that Americans no longer meaningfully identify with, or feel strong loyalties to, their states. This assumption has led some scholars to reject federalism altogether; others argue that federalism must be reoriented to serve national values. But the issue of identity and loyalty sweeps far more broadly, implicating debates about the political safeguards of federalism, the ability of states to check national power, and the likelihood that states will produce policy innovations or good opportunities for citizen participation in government. The ultimate question is whether American federalism lacks the cultural and psychological support to sustain itself.

This article is the first comprehensive effort to assess whether contemporary American states are meaningfully distinctive from one another and whether contemporary Americans identify with their states. The death of state identity is an empirical claim, but no proponent of that claim has ever marshalled empirical evidence to support it. It is also a claim unique to legal scholarship: Scholars in political science, history, economics, cultural psychology, and other disciplines have developed extensive literatures on state political cultures. This article surveys those literatures and collects evidence on the states' geographic, demographic, and policy diversity, states' impact on political preferences, relative trust in state and federal institutions, state's distinct historical narratives, and the impact of individual mobility among the states. I conclude that
\end{abstract}

\footnotetext{
* Alston \& Bird Professor of Law, Duke Law School. I am grateful to Tom Barnico, Erin Blondel, Jim Gardner, Heather Gerken, Abner Greene, Ethan Leib, Maggie Lemos, Eric Soskin, Zephyr Teachout, seminar and colloquia participants at Alabama, Chicago, Duke, Florida State, Fordham, Minnesota, Notre Dame, Texas, and Yale for helpful comments, and to Philip Alito, John Bailey, Jennifer Bandy, Sarah Campbell, Lee Czocher, Kim Jolson, Grant Mannion, and Christine Wells for research assistance. This essay is for my parents, Bob and Nell Young, who raised me to love both Texas and America.
} 
reports of the death of state identity are greatly exaggerated - and that has important implications for American federalism.

\section{Table of Contents}

I. American Federalism and the "One Nation" Argument ........................................ 8

II. What is State Identity, and How Do We Tell If It's Dead? ...................................... 14

A. Identity, Distinctiveness, and Political Culture......................................... 18

B. Distinctiveness, Identity, and the Ends of Federalism ................................ 31

C. Looking for Political Community in the States ............................................38

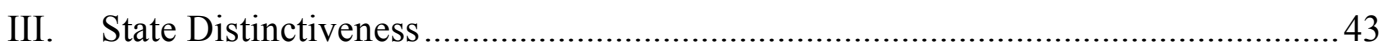

A. How Different are the States? Policy Inputs .............................................46

1. The Land 47

2. Demographics and Social Capital 50

3. State Economies $\quad 54$

4. State Political Culture 59

B. How Different are the States? Policy Outputs ............................................66

1. State Constitutions 69

2. State Policy Divergence: A Sampler 76

3. The Red and the Blue 83

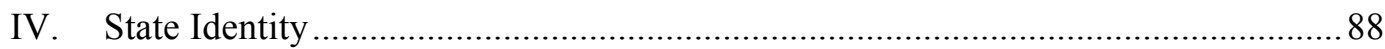

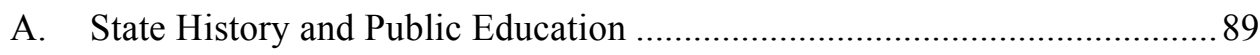

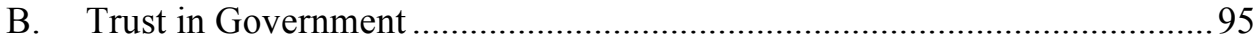

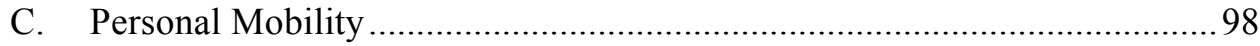

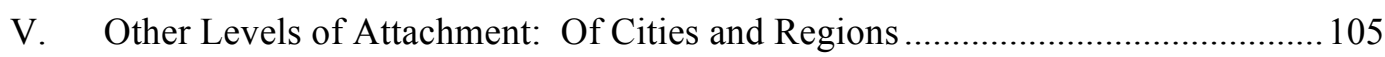

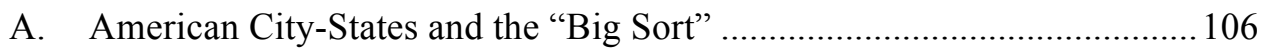

B. Regionalism in the American Federal System ..........................................110

VI. Loyalty, Treason and the Paradox of Identity in a Multi-Level Polity.................. 114

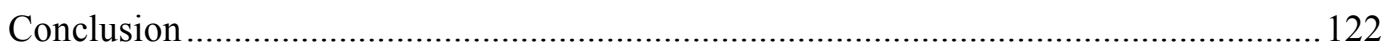


What, then, will become of federalism if it has lost social support but retained its formal structure?

$$
\text { - Aaron Wildavsky }{ }^{1}
$$

In the spring of 1861, General Winfield Scott asked Robert E. Lee, then a colonel in the U.S. Army, to take command of the Union's field forces and put down the Rebellion. Colonel Lee respectfully declined and resigned his commission. He explained his decision in a letter to his sister:

With all my devotion to the Union and the feeling of loyalty and duty of an American citizen, I have not been able to make up my mind to raise my hand against my relatives, my children, my home. I have therefore resigned my commission in the Army, and save in defense of my native State, with the sincere hope that my poor services may never be needed, I hope I may never be called on to draw my sword. ${ }^{2}$

Lee's decision - to place his loyalty to his State before his loyalty to his Nationprobably seems inconceivable to most modern Americans. Modern attitudes might be better captured in a comment by Anthony Bourdain on a movement to have New Jersey_which lacks an official state song-adopt Bruce Springsteen's classic "Born to Run." Mr. Bourdain acknowledged that "Bruce was, and likely remains, New Jersey's most famous product, our proudest citizen, our bard, our voice." "3 But as Bourdain mischievously points out, of course, "Born to Run" is a song "about getting the f_k out of Jersey."4

As Mr. Bourdain's quip suggests, many contemporary Americans have a hard time taking state identity seriously. To be sure, regional distinctiveness survives to a greater degree than many bicoastal academics might credit. But even those of us who self-identify as "Texans" or "Californians" or "Vermonters" hardly view that attachment

\footnotetext{
${ }^{1}$ Aaron Wildavsky, Federalism \& Political Culture 45 (D. Schleicher \& B. Swedlow, eds. 1998).

${ }^{2}$ Letter to Mrs. Marshall, April 20, 1861, quoted in 1 Douglas Southall Freeman, LeE: A BIOGRAPHY 443 (1934).

${ }^{3}$ Anthony Bourdain, New Jersey, in, State by State: A Panoramic Portrait of America 300, 301 (Matt Weiland \& Sean Wilsey, eds. 2009) [hereinafter StATE By STATE].

${ }^{4} I d$. (quote modified to preserve the status of this journal as a family publication).
} 
in the same sense as our national citizenship: When patriotism is discussed, it is allegiance to the nation..$^{5}$ And for a large and (seemingly) ever-growing number of us, states are simply places where we happen to live.

This essay undertakes, for the first time in the contemporary federalism literature, to explore whether distinctive state identities are really dead in America, and whether, and in what sense, that matters for American federalism. Ever since the Rehnquist Court began reviving the notion of constitutional limitations on national power in the early 1990s, ${ }^{6}$ American legal scholars have rejoined the age-old debate on the relationship between national and state "sovereignty." That debate has become even more salient as an important social movement presses for further limitations on national power, ${ }^{8}$ the Supreme Court continues to decide landmark cases on the scope of both national and state power, ${ }^{9}$ and Europe's great federal experiment confronts fundamental questions

${ }^{5}$ See, e.g., Martha C. Nussbaum, For Love of Country: Debating the Limits of PATRIOTISM (Joshua Cohen, ed. 1996) [hereinafter Nussbaum, Love OF CounTRY] (debating with various respondents the morality of cosmopolitanism versus nationalism, with nary a mention of loyalty to states).

${ }^{6}$ See, e.g., New York v. United States, 505 U.S. 144 (1992) (striking down certain provisions of the federal Low-Level Radioactive Waste Policy Amendments Act of 1985 on the ground that they improperly "commandeered" state legislative processes); United States v. Lopez, 514 U.S. 549 (1995) (striking down the federal Gun-Free School Zones Act of 1990 on the ground that it fell outside Congress's power under the Commerce Clause). For a general survey, see Ernest A. Young, The Rehnquist Court's Two Federalisms, 83 TEXAS L. REV. 1 (2004) [hereinafter Young, Two Federalisms].

${ }^{7}$ See, e.g., Heather K. Gerken, The Supreme Court, 2009 Term-Foreword: Federalism All the Way Down, 124 Harv. L. Rev. 4 (2010) [hereinafter Gerken, All the Way Down]; Timothy Zick, Are the States Sovereign?, 83 WASH. U. L.Q. 229 (2005); Ernest A. Young, Federalism as a Constitutional Principle, _ U. CINN. L. REV. _ , (forthcoming 2015) [hereinafter Young, Taft Lecture].

${ }^{8}$ See, e.g., Elizabeth Price Foley, The Tea Party: Three Principles (2012); Ilya Somin, The Tea Party Movement and Popular Constitutionalism, 105 Nw. U. L. REV. 300 (2011).

${ }^{9}$ See, e.g., National Federation of Independent Business v. Sebelius, 132 S. Ct. 2566 (2012) (upholding the Affordable Care Act's "individual mandate" that all persons purchase health insurance as a valid exercise of the taxing power, but striking down Congress's effort to require states participating in Medicaid to expand coverage as an impermissible use of the spending power); Arizona v. United States, 132 S. Ct. 2492 (2012) (striking down most of Arizona's effort to ratchet up immigration enforcement as preempted under the federal immigration laws). 
about the ability and willingness of historically separate nations to function as one economy. ${ }^{10}$ Although the federalism debate in this country is often conducted in doctrinal terms, ${ }^{11}$ federalism doctrine is, to at least some extent, driven by and predicated on certain assumptions about the States. Where you stand on federalism doctrine is largelyalthough not entirely - a function of whether you think states are worth caring about.

Contemporary American debates about federalism have featured claims that state sovereignty is unnecessary, undesirable, and indeed unsustainable in the absence of commitments like Colonel Lee's - that is, without the sort of social divisions that lead people to identify primarily with a subnational unit. ${ }^{12}$ Robert Schapiro, for example, argues that the Supreme Court need not protect enclaves of state policy autonomy because such autonomy would be meaningful only if it reflected distinctive state political communities - which no longer exist. ${ }^{13}$ Malcolm Feeley and Edward Rubin go so far as to assert that because all citizens of our Republic identify with the nation, federalism should not-and does not—exist at all. ${ }^{14}$ Other scholars draw more limited conclusions. Jim Gardner has insisted that the death of distinctive state identities should inform debates about interpretation of state constitutions, ${ }^{15}$ while Jessica Bulman-Pozen suggests that the states should be seen simply as narrower arenas for partisan competition between

${ }^{10}$ See, e.g., Johan van Overtveldt, The End of the Euro: The UnEasy Future of the EUROPEAN UNION (2011); see also JURGEN HABERMAS, THE CRISIS OF THE EUROPEAN UNION: A RESPONSE (2012) (recognizing that the European crisis is not simply one of economics but one of political identity).

${ }^{11}$ See, e.g., Neil Siegel, ed., The Constitutionality of the Affordable Care Act: Ideas from the Academy, 75 L. \& CONTEMP. Probs., No. 3 (2012) (collecting articles); see generally Ernest A. Young, Making Federalism Doctrine: Fidelity, Institutional Competence, and Compensating Adjustments, 46 WM. \& MARY L. ReV. 1733 (2005).

${ }^{12}$ See Edward L. Rubin, Puppy Federalism and the Blessings of America, 574 Annals AM. ACAD. POLI. \& SOC. SCI. 37 (2001).

${ }^{13}$ Robert A. SCHAPIRO, Polyphonic Federalism: TOWARd the Protection of Fundamental RIGHTS (2009).

${ }^{14}$ Malcolm M. Feeley \& Edward Rubin, Federalism: National Identity and Tragic COMPROMISE (2008).

${ }^{15}$ See, e.g., James A. Gardner, Interpreting State Constitutions: A Jurisprudence of FUnCTION IN A FEDERAL SYSTEM (2005). 
essentially the same broad forces that dominate American politics as a whole. ${ }^{16}$ But the common premise - widely shared throughout the contemporary federalism literature - is that most contemporary Americans no longer feel the strong sense of attachment to their states that Colonel Lee felt for Virginia or Mr. Springsteen feels for New Jersey.

This view—which I call the "One Nation" argument—is a prominent and recurrent position. The prominent New Dealer and public administration scholar Luther Gulick proclaimed in 1933 that "[t]he American state is finished. I do not predict that the states will go, but affirm that they have gone." ${ }^{17}$ In the late 1960s, Robert Dahlspeaking as the president of the American Political Science Association-insisted that "the states do not stand out as important institutions of democratic self-government" and denied "that the states, on the whole, can tap any strong sentiments of loyalty or likemindedness among their citizens."18

The One Nation argument sees distinctive state identities as the purpose or end of federalism: constitutional limits on national power accommodate preexisting distinctive communities of persons who self-identify with their state communities. Absent such identities, the argument holds, there is no need for federalism as it has been traditionally understood. ${ }^{19}$ But the significance of state identity is not limited to this particular (and extreme) academic claim. Rather, identity plays a central-but almost universally unacknowledged - role with respect to three broader sets of federalism questions.

First, a vigorous and longstanding debate about the "political safeguards of federalism" posits that various kinds of political actors-Members of Congress, state political party officials, state bureaucrats tasked with implementing federal statutory schemes - can protect state prerogatives through political and bureaucratic means, so that the courts can eschew, or at least scale back, judicial review to maintain the federal balance. ${ }^{20}$ But that only works if these officials feel some sort of loyalty to their states.

${ }^{16}$ Jessica Bulman-Pozen, Partisan Federalism, 127 HARV. L. REV. 1077, _ (2014).

${ }^{17}$ Luther Gulick, Reorganization of the State, 3 Civil ENGINEERING 420, 421 (1933).

${ }^{18}$ Robert A. Dahl, The City in the Future of Democracy, 61 AM. PoL. SCI. REv. 953, 968 (1967).

${ }^{19}$ See FeELEy \& RUBin, supra note 14, at 52.

${ }^{20}$ See generally Herbert Wechsler, The Political Safeguards of Federalism: The Role of the States in the Composition and Selection of the National Government, 54 Colum. L. Rev. 543 (1954); Lynn A. Baker, Putting the Safeguards Back into the Political Safeguards of Federalism, 46 VILL. L. REV. 951 (2001). 
Second, a broad literature on the benefits of federalism posits that states will experiment and compete through policy innovation, and that states provide a good opportunity for mass political participation because they're closer to the people. These dynamics are often analyzed in terms of Albert Hirschman's famous theory of exit and voice. ${ }^{21}$ But that theory posited an important but underdeveloped role for loyalty. Loyalty, for instance, is what causes dissatisfied people to stick around and raise their voice rather than exiting the jurisdiction. And loyalty to a state may help the losers of political fights accept the outcome as legitimate. Opponents of same-sex marriage in a state, for instance, may be more inclined to accept the recognition of those marriages as legitimate if it's the decision of a smaller political community in which they feel a meaningful sense of membership. ${ }^{22}$ We cannot assess the potentially crucial role of loyalty without a better sense of how much loyalty to states is out there.

Finally, both James Madison and Alexander Hamilton explained the Framers' theory of vertical checks and balances as grounded in a competition for loyalty between the national government and the States. ${ }^{23}$ It was important to this theory that neither side totally win this competition. The ideal was that each citizen would have significant loyalties to each political community, which would allow her to appeal to one when the other was misbehaving. The question, of course, is whether loyalties to states remain strong enough to provide a plausible alternative to national loyalty in times of stress. Think, for instance, about Virginia and Kentucky's resistance to the Alien and Sedition Acts, Oregon's resistance to the Patriot Act, California's effort to fill the gap left by national inaction on global warming and air pollution, Texas's and Arizona's differing critiques of national immigration policy, or Colorado and Washington's effective nullification of federal marijuana laws. Citizens' loyalty to these jurisdictions figures

\footnotetext{
${ }^{21}$ Albert O. Hirschman, Exit, Voice, and Loyalty: Responses to Decline in Firms, ORGANIZATIONS, AND STATES (1970).

${ }^{22}$ See, e.g., Ernest A. Young, Exit, Voice, and Loyalty as Federalism Strategies: Lessons from the Same-Sex Marriage Debate, 85 U. Colo. L. REV. 1133 (2014) [hereinafter Young, Same-Sex Marriage].

${ }^{23}$ See, e.g., Todd Pettys, Competing for the People's Affection: Federalism's Forgotten Marketplace, 56 VAND. L. REV. 329 (2003); Jacob T. Levy, Federalism, Liberalism, and the Separation of Loyalties, 101 AM. POL. SCI. REV 459, 465 (2007) (observing that, for the Federalists, "[1]oyalty to the states ... [was] the general protection against the new constitutional order going awry")
} 
prominently in assessing whether we can expect such forms of dissent to persist or succeed. ${ }^{24}$

There is thus a great deal at stake in debates about state identity. And these issues are as crucial now as it has been since the mid $-19^{\text {th }}$ century. Our politics reflects deep division over issues of economic and social policy, on issues from healthcare to same-sex marriage to immigration. Federalism may offer a way to live with these disagreements by vesting policymaking authority in smaller communities better able to reach consensus on divisive issues and allowing rights of exit to those opposed to the decisions reached in the jurisdiction where they live. But this only works if the states themselves represent meaningful communities of value. The One Nation argument thus dominates any other debates about federalism we might have.

The death of state identity is an empirical claim, and that claim remains completely unproven. In order to get to the bottom of it, this article undertakes two tasks. First, I clarify what we mean by state identity and why it matters for federalism. In so doing, I canvass a wide and interdisciplinary set of work that has been largely neglected in the legal literature. Second, I survey - for the first time - a broad range of empirical research, as well as other forms of evidence, that bears on the death or persistence of state identity. The claim that state identity is dead has considerable intuitive appeal for law professors, and perhaps for other elites as well, but we are hardly a representative sample. In any event, the One Nation argument has got by on bare assertion for far too long. Evidence is out there, and it strongly suggests that the states remain quite distinctive in key ways, and that state identity remains a highly plausible concept both empirically and conceptually.

I explore these issues in six parts. Part One develops the One Nation argument and its conception of the relationship between identity and federalism. Part Two unpacks the notion of "state identity" and explains why it has significance beyond the One Nation argument. In particular, I distinguish between two related concepts: distinctiveness and identity. Part Three focuses on state distinctiveness. I review a variety of facts about the states - their geography, demography, economic characteristics, as well as their history and politics - and discuss how these characteristics have shaped distinctive notions of state political culture. Part Four then turns to identity. Because it is difficult to measure

${ }^{24}$ See, e.g., Ernest A. Young, Marijuana, Nullification, and the Checks and Balances Model of Federalism, in NeO-NulLifiCATION AND NeO-SECESSIONISM (Sanford Levinson, ed., forthcoming 2015). 
identity directly, I explore several possible proxies, such as state efforts to preserve their own history, survey evidence concerning public trust in governmental institutions, and the extent of personal mobility in the contemporary United States. None of this evidence can conclusively demonstrate that most Americans have strong political commitments to distinctive state communities, but I believe there is sufficient evidence to disprove the One Nation proponents' easy assumption that the states have been assimilated into a homogeneous mass. Americans' political commitments remain —as they have always been-complicated enough to defy simple generalizations. But the states plainly matter more than the One Nation argument acknowledges.

Parts Five and Six consider, respectively, two possible counterarguments. In Part Five, I address whether Americans' subnational identities, to the extent they exist, might more plausibly be focused on either local or regional communities. I conclude that while these identities may well be more salient for some people and in some places, they do not eclipse the importance of state identities. Not only does public opinion data indicate that states retain an importance independent of locality or region, but states provide an institutional reference point that neither regions nor localities can match. Part Six addresses the normative criticism that state identities are dangerous. As Colonel Lee's story suggests, state identities may threaten the national identity and even, in some cases, amount to treason. ${ }^{25}$ Although one must acknowledge this danger, it seems equally likely that identity is additive rather than competitive - that is, that loyalties to the part may actually strengthen identity with the whole. In any event, state identities are only one category of competitors that threaten to undermine our ideal of national identity. And as more particularistic identities go, state identities may be considerably less threatening to social solidarity than many of the alternatives.

I suspect that Robert E. Lee's Virginia holds relatively little attraction even for those of us who care deeply about federalism. But the extreme circumstances and nature of Colonel Lee's choice should not obscure the fact that our Founders envisioned Americans with dual loyalties to their states and to the nation, and that these loyalties were meant to serve as an integral part of the political system of checks and balances. ${ }^{26}$

\footnotetext{
${ }^{25}$ See, e.g., Richard Cohen, Dispelling the Myth of Robert E. Lee, WASH. Post, April 25, 2011, available at http://www.washingtonpost.com/opinions/dispelling-the-myth-of-robert-elee/2011/04/25/AFrXC1kE story.html (arguing that Lee "was loyal to slavery and disloyal to his country—not worthy ... of the honors accorded him").

${ }^{26}$ See, e.g., THE FedERALIST No. 28 (Alexander Hamilton).
} 
Across our contemporary political landscape, Americans are using their states as critical vehicles to diverge from national policy on issues from same-sex marriage, drug policy, and environmental protection to healthcare and immigration. ${ }^{27}$ These processes of dissent and experimentation presuppose that states are meaningful political communities able to draw upon a reservoir of popular loyalty and support. New Jersey may not need a volk to participate in these processes, but it does need citizens who care for it. The question of state identity thus implicates the very wellsprings of American federalism.

\section{American Federalism and the "One Nation" Argument}

Any account of federalism must rest on an understanding of the role states play in the political system. Constitutional text and history contribute to that understanding, but the underlying issues are political, cultural, even psychological. Doctrines of enumerated and reserved powers rest on assumptions about the respective political and cultural roles of the national and state governments. Arguments about the anti-commandeering doctrine or the political safeguards of federalism depend on intuitions about the loyalties of both elected officials and their constituents. These largely unexamined assumptions pervade the federalism literature and case law. Extreme claims about them-like the "One Nation" argument highlighted here- throw the issues into high relief, but those claims are just the tip of the iceberg. No issue of federalism doctrine or theory is entirely separable from the question of what the states are, and whether people care about them.

Edward Rubin, who once taught across the Delaware River from New Jersey at the University of Pennsylvania, proclaimed the death of American state identity over a decade ago in a well-known essay with the catchy title of Puppy Federalism. ${ }^{28}$ Dean Rubin argued that polities opt for federalism as an organizing principle only to cope with "a basic lack of national unity, an unwillingness of some groups to submit themselves to centralized control, to regard themselves as members of a single polity that must, for

\footnotetext{
${ }^{27}$ See, e.g., Young, Same-Sex Marriage, supra note 22, at 1135-36; Heather K. Gerken, A New Progressive Federalism, DEMOCRACY, Spring 2012, available at http://www.democracyjournal.org/24/a-new-progressive-federalism.php?page=all [hereinafter Gerken, Progressive Federalism]; Robert A. Mikos, On the Limits of Supremacy: Medical Marijuana and the States' Overlooked Power to Legalize Federal Crime, 62 VAND. L. REV. 1421 (2009).

${ }^{28}$ See Rubin, supra note 12. Dean Rubin's essay built on a more extended article, with another catchy title, that he wrote with Malcolm Feeley in 1994. See Edward Rubin \& Malcolm Feeley, Federalism: Some Notes on a National Neurosis, 41 U.C.L.A. L. REV. 903 (1994).
} 
better or worse, reach collective decisions." ${ }^{29}$ Building on this observation in a more recent book, Dean Rubin and Malcolm Feeley characterized the need for federalism to accommodate clashing identities as a "tragic compromise." 30

The critical issue for Dean Rubin and Professor Feeley is precisely Colonel Lee's question: "whether [the citizen] regards herself primarily as a member of the nation or as a member of the subunity to which she belongs." United States was a nation that needed federalism," 32 Rubin thinks that those days are now plainly behind us:

At present, the United States is a socially homogenized and politically centralized nation. Regional differences between different parts of the nation are minimal, and those that exist are based on inevitable economic variations, rather than any historical or cultural distinctions. ... With the minor exceptions of Utah and Hawaii, there is no American state with a truly distinctive social profile. . . . Our political culture is more uniform still. . . . Most important, the primary political loyalty of the vast majority of Americans is to the nation. ${ }^{33}$

It follows that the death of state identity makes federalism largely irrelevant. Rubin and Feeley explain that "[o]nly when [the people's] identity is divided between the nation and a geographic region or exclusively linked to such a region will they want the region to possess some level of autonomy, so that it can make choices that the center cannot

\footnotetext{
${ }^{29}$ Rubin, supra note 12 , at 40 .

${ }^{30}$ FeELey \& RUBIN, supra note 14; see also Ernest A. Young, What Does It Take to Make a Federal System? On Constitutional Entrenchment, Separate Spheres, and Political Identity, 45 TUlSA L. REV. 831 (2011) [hereinafter Young, Review] (reviewing both the Schapiro and the Feeley and Rubin books). One might have hoped, now that Dean Rubin makes his home at Vanderbilt Law School in Nashville, Tennessee - just twelve miles from the Grand Ole Opry!that he might not still think all the states are the same. But the new book restates and builds upon the argument that Rubin and Professor Feeley have been making since 1994.

${ }^{31}$ Rubin, supra note 12, at 40; see also FEELEY \& RUBIN, supra note 14, at 61(asserting that the "attitudinal criteria" for federalism are "the willingness to die and the willingness to kill" on behalf of a separate, subnational community); but see infra at (questioning these criteria).

${ }^{32}$ Rubin, supra note 12 , at 43.

${ }^{33} I d$. at $45-46$.
} 
countermand. In other words, regional autonomy will only be appealing to people if the region itself is meaningful to people, that is, if it relates to their sense of political identity." ${ }^{34}$

Because we no longer need real federalism, Dean Rubin argues, all that persists is "a certain nostalgia for our bygone federalist system" motivated by mistaken notions of constitutional fidelity, anti-regulatory politics, and "the yearning of many Americans for the simplicity of the premodern era." 35 This diagnosis is consistent with Rubin's and Feeley's earlier psychoanalysis of federalism as a "national neurosis." 36 In a somewhat more gentle mode, Dean Rubin argued that our federalist structure of vertical separation of powers has atrophied into "puppy federalism; like puppy love, it looks somewhat authentic but does not reflect the intense desires that give the real thing its inherent meaning. ${ }^{, 37}$ Feeley and Rubin attribute the (supposed) incoherence of Supreme Court doctrine on the subject to this lack of an actual need for federalism. "It is time," Rubin

\footnotetext{
${ }^{34}$ FEELEY \& RUBIN, supra note 14 , at 16 . This is, to put it mildly, not necessarily so. As many scholars have demonstrated, particular states may slice the national electorate differently, so that national minorities are local majorities. See infra notes _ _ _ and accompanying text. Those national minorities may strongly prefer state autonomy, which allows them to exercise power, even if they have no particular attachment to the state as a matter of personal identity. See, e.g., Bulman-Pozen, supra note 16, at _. I prefer, however, to jump off the Rubin-Feeley train at a different point. For a more focused critique of the entire argument, see Ernest A. Young, What Does It Take to Make a Federal System? On Constitutional Entrenchment, Separate Spheres, and Political Identity, 45 TUlSA L. Rev. 831 (2011) (reviewing both the Schapiro and the Feeley and Rubin books).

${ }^{35}$ Rubin, supra note 12, at 46.

${ }^{36}$ See Rubin \& Feeley, supra note 28.

${ }^{37}$ Rubin, supra note 12 , at 38.

${ }^{38}$ See Rubin \& Feeley, supra note 28, at 126 ("Because federalism has ceased to be an operative principle in modern American government, decisions that strike down national legislation in its name are little more than either random firings of a nostalgia-driven dissatisfaction with modernity or political tropisms that reflect the judges' underlying views about substantive and otherwise nonjusticiable matters of policy."). One could certainly quibble about whether the Court's federalism doctrine is any more incoherent than, say, its doctrine on separation of powers, equal protection, or fundamental rights. Constitutional law is hard, and it rarely lends itself to simple solutions.
} 
concludes, "to stop being fooled by political rhetoric and mistaking puppy federalism for the real thing. Real federalism is gone; America is a centralized administrative state." 39

I will call this position the "One Nation" argument. For Dean Rubin and Professor Feeley, it is an argument for abandoning federalism altogether. But the argument need not pay out in that way; as Robert Schapiro's recent work suggests, the One Nation thesis may argue instead for re-orienting our federalism to serve the objectives of the national political community. "To the extent that states do reflect integral communities of value, with moral and cultural views different from those of other states, then allocating certain kinds of power to the states make sense," Dean Schapiro writes, but "[w]ithout division on key principles, federalism is not necessary.",40 In place of traditional or "dualist" models of federalism, however, Schapiro advocates a "polyphonic" conception that would "protec $[\mathrm{t}]$. . . the institutional integrity of multiple sources of power and . . promot[e] . . . the dynamic interaction of those centers of authority." ${ }^{41}$ All of this is meant to further a fundamental shift in federalism's orientation: Federalism should no longer be about drawing boundaries between state and federal power, but rather a means of harnessing the capacities of both state and federal governments to serve national ends. ${ }^{42}$

James Gardner's work on state constitutionalism deploys the One Nation argument in a more focused way. Much of Professor Gardner's work rejects "characterbased" interpretation of state constitutions - that is, interpretation relying on the notion that "the people of the various states have demonstrably distinct characters of their own," such that "state constitutions ... are self-conscious expressions of the values and

\footnotetext{
${ }^{39}$ Id. at 49.

${ }^{40}$ SCHAPIRO, supra note 13 , at 27.

${ }^{41} I d$. at 96 . In music, polyphony describes "the simultaneous and harmonious combination of a number of individual melodic lines" - as in Bach's fugues or Pachelbel's canon. Id. at 94 (quoting OXFORD ENGLISH Dictionary OnLINE (draft revision June 2007), http://www.oed.com/). While Rubin and Feeley urge that any decentralization in our system should not be constitutionally entrenched, see FEeley \& RUBIN, supra note 14, at 50-54, Schapiro's conception "remains federalist" in the sense that "the allocation of authority between the states and the national government has constitutional status," but this constitutional allocation does not protect exclusive domains of state authority. SCHAPIRO, supra note 13, at 96-97.

${ }^{42}$ See id. at 176.
} 
character of the respective state polities." ${ }^{\text {43 }}$ Gardner thus attacks notions of "romantic subnationalism" that would recognize any meaningful form of state political identity. ${ }^{44}$ For him, "a view of the American states as distinct and cohesive political subcommunities whose inhabitants comprise peoples with integrated histories and corresponding sets of values that suffice to set them apart not only from one another, but from the national community" is "not only implausible on its own merits, but points us down exactly the wrong path." 45

Although important differences separate these scholars, they each reject traditional notions of constitutional federalism based on a judgment that the American states are no longer distinctive in any meaningful way. Their positions implicitly assume that the citizens of any given state will not strongly identify with that state unless it is distinctive in some important way from other states. And because the states do not, in Dean Schapiro's phrase, "reflect integral communities of value," 46 these positions infer that there is no particular reason to protect their constitutional autonomy to make policy choices different from those of the national government. ${ }^{47}$ This, then, is the One Nation argument: Traditional conceptions of federalism are obsolete in a world where Americans no longer strongly identify with their states.

Dean Rubin's and Professor Feeley's assertion that we are one nation revolves around a central empirical claim - that the American people, sociologically speaking, feel no significant loyalty to their states - and yet makes no attempt to come forward with

\footnotetext{
${ }^{43}$ See GARDNER, supra note 15, at 53-54. See also James A. Gardner, Southern Character, Confederate Nationalism, and the Interpretation of State Constitutions: A Case Study in Constitutional Argument, 76 TexAs L. Rev. 1219 (1998) [hereinafter Gardner, Southern Character]; James A. Gardner, The Failed Discourse of State Constitutionalism, 90 MICH. L. REV. 761, 818 (1992) [hereinafter Gardner, Failed Discourse].

${ }^{44}$ See GARDNER, supra note 15 , at 53.

${ }^{45} I d$. at 56.

${ }^{46}$ SCHAPIRO, supra note 13 , at 27.

${ }^{47}$ Professor Schapiro does think that the Constitution protects "the institutional integrity of states" and "[t]he continued functioning of each state's political apparatus." Id. at 96 . But that protection does not extend to limit national power to encroach on the States' regulatory jurisdiction. Id. at 9697.
} 
evidence to support that claim. ${ }^{48} \mathrm{We}$ ought, as scholars, to be able to do a little better than that. Many law professors spend much of their time in either large metropolitan areas or university towns, and many of us teach at "national law schools" that virtually ignore state law. We ought to be on the lookout for "availability bias"- that is, the fallacy of generalizing from one's own experience. ${ }^{49}$ The likelihood that most law professors experience a relatively homogeneous national community with relatively little state-by-state variation doesn't establish that other Americans live the same way.

This essay tries to get some empirical traction on the question of state identity. The importance of that question transcends the One Nation argument. Another important school of thought, exemplified by Heather Gerken and Jessica Bulman-Pozen, ${ }^{50}$ accepts the notion that citizens no longer identify with their states but maintains that American federalism nonetheless provides important benefits, such as the opportunity for national minorities to exercise power in states where they happen to enjoy majority support. ${ }^{51}$ This view tends to assume that the only thing distinctive about any given state is that it may offer a different correlation of political forces from the nation as a whole, and that citizens' attachments to their states reflect only the instrumental value of the political unit in achieving their policy goals. ${ }^{52}$ Although this "Partisan Federalist" view would retain the federal structure for instrumental reasons, discounting notions of identity and

\footnotetext{
${ }^{48}$ Indeed, those steeped in the empirical detail of state and local politics tend to come to the opposite conclusion - that is, that federalism remains necessary to accommodate the vast diversity of American politics. See Michael Barone, Shaping Our Nation: How Surges of Migration Transformed AMERICA AND Its Politics 12-13 (2013); Virginia Gray, The Socioeconomic and Political Context of States, in Politics in the American States: A Comparative Analysis 1, 6 (Virginia Gray \& Russell L. Hanson, eds., $8^{\text {th }}$ ed. 2004).

${ }^{49}$ See DANiel Kahneman, ThinkIng, FAST AND Slow 129-36 (2011) (discussing the availability bias); Andrew Gelman, Red State, Blue State, Rich State, Poor State: Why Americans VOTE THE WAY THEY Do 36-37 (2008) (arguing that availability distorts the way we think about states).

${ }^{50}$ [cites]

${ }^{51}$ See, e.g., Gerken, Progressive Federalism, supra note 27; Heather K. Gerken, Dissenting by Deciding, 56 Stan. L. Rev. 1745 (2005); see also Bulman-Pozen, supra note 16, at _ (arguing that states play an important role in partisan competition because, at any given time, each party will control a certain number of states).

${ }^{52}$ See, e.g., Bulman-Pozen, supra note 16, at 1110 (denying that the states are inherently distinctive).
} 
attachments has important implications for explaining how our federalism operates and what is necessary to preserve it. ${ }^{53}$

Likewise, longstanding debates about the extent to which courts should enforce constitutional limits on national power have focused on various "political safeguards" of federalism as an alternative to judicial review. ${ }^{54}$ These safeguards include the representation of the states in Congress, the links between national and state-level political parties, and various entities that make up the intergovernmental lobby. ${ }^{55}$ Similar claims have been made concerning the ability of state executive officials to influence federal policy and resist federal mandates in the context of cooperative federalism arrangements. ${ }^{56}$ The plausibility of all these arguments and the vigor of the safeguards for state autonomy that they posit depend in significant part on the degree of loyalty that a state's federal representatives, political party officials, and executive officers feel toward the state as a distinct political community. For all these reasons, then, it is worth exploring the current state of state identity.

\section{What is State Identity, and How Do We Tell If It's Dead?}

Not long ago, the Garden State fended off a proposal by the federal Office of Management and Budget to roll North and South Jersey into newly designated "megapolitan" areas of New York and Philadelphia for census purposes. ${ }^{57}$ This proposal would have lent the Presidential imprimatur to the old saw that New Jersey is a state

\footnotetext{
${ }^{53}$ See, e.g., Young, Same-Sex Marriage, supra note 22, at __; Young, Marijuana Nullification, supra note 24 , at

${ }^{54}$ See, e.g., Wechsler, supra note 20.

${ }^{55}$ See Larry D. Kramer, Putting the Politics Back Into the Political Safeguards of Federalism, 100 Colum. L. Rev. 215 (2000); John D. Nugent, Safeguarding Federalism: How States PROTECT THEIR INTERESTS IN NATIONAL POLICYMAKING (2009).

${ }^{56}$ Heather K. Gerken, Exit, Voice, and Disloyalty, 62 Duke L. J. 1349 (2013); Jessica BulmanPozen \& Heather K. Gerken, Uncooperative Federalism, 118 YALE L. J. 1256 (2009).

${ }^{57}$ See Angela Starita, Census, Restoring State's Identity, N.Y. TiMES, Sept. 10, 2000, available at http://query.nytimes.com/gst/fullpage.html?res=9A0DE6DB1339F933A2575AC0A9669C8B63;

Executive Office of the President, Recommendations From the Metropolitan Area Standards Review Committee to the Office of Management and Budget Concerning Changes to the Standards for Defining Metropolitan Areas, Part IV, 64 Fed. Reg. 56628 (Oct. 20, 1999).
} 
whose two principal cities lie outside its borders. ${ }^{58}$ From OMB's perspective, "New Jersey" would have ceased to exist. OMB's general willingness to redefine relevant political communities without regard to state borders appears symptomatic of Dean Rubin's contention that the American states have become homogenized. We can all cite examples from our own experience to bolster that contention. As Matt Weiland laments, "one city blurs into another; the same architects build the same buildings, the same stores line the same streets, the same songs play on the radio; regional accents fade and everyone seems to be from somewhere else." 59

I chose New Jersey for my title because, at least in the popular mind, it epitomizes Mr. Weiland's worry about the death of distinctive state character. A longstanding tradition describes the Garden State as generic. Writing in the 1920s, Edmund Wilson devastatingly described it as a place "where people do not live to develop a society of their own but where they merely pass or sojourn on their way to do something else." ${ }^{\circ 0}$ Contemporary writers strike much the same note. Luc Sante wrote in 2003 that "the state's identity is pretty thin. . . . The New Jerseyan is generally seen as the embodiment of upwardly mobile rootlessness and material self-satisfaction." ${ }^{\prime \prime 1}$ The state has come a long way from a time when "New Jersey troops reporting for duty at

\footnotetext{
${ }^{58}$ See, e.g., Edmund Wilson, Jr., New Jersey: The Slave of Two Cities, in, ThESE United STATES: PORTRAITS OF AMERICA FROM THE 1920s 243, 243 (Daniel H. Borus, ed. 1992) (first published June 14, 1922) [hereinafter THeSE United STATES 1920s] ("The chances are . . that New Jersey seems to you essentially a region that one traverses to go somewhere else, a kind of suburb and No Man's Land between New York and Philadelphia.").

${ }^{59}$ Matt Weiland, Preface, in State By State, supra note 3, at xiv.

${ }^{60}$ Wilson, supra note 58 , at 243 . On the other hand, nearly every time that I have presented this paper to colloquia around the country (not yet in New Jersey, alas), someone has collared me afterwards to insist that New Jersey does, in fact, have a distinctive identity. The asserted distinctiveness nearly always has something to do with either Bruce Springsteen ${ }^{60}$ or the Sopranos. See, e.g., Bourdain, supra note 3 , at 301 .

${ }^{61}$ Luc Sante, New Jersey: On Mediocrity's Cutting Edge, in John LeONARD, ED., These United

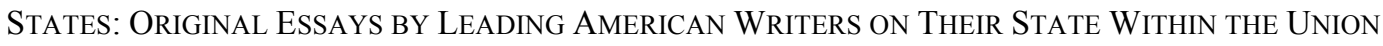
271, 274 (2003) [hereinafter THESE UnitED STATES 2003].
} 
Valley Forge ... . initially refused to swear allegiance to the 'United States of America' because, as they said, 'New Jersey is our country.",62

This transformation of New Jersey fits into a broader and familiar historical narrative. The American colonies were highly diverse at the Founding in terms of demographics, systems of government, religious belief, and economic interests, and Americans felt strong loyalties toward their newly-independent state communities. ${ }^{63}$ But "[i]n the last half of the eighteenth century the peoples of the colonies and states developed a common American identity that coexisted with other, primarily state and local, identities." ${ }^{64}$ Foreign threats to the early Republic strengthened this sense of nationhood, but as those threats subsided and disputes arose between North and South, "[s]ectional and economic identities emerged and increasingly divided the country, leading to the Civil War." 65 "That war," Samuel Huntington explains, "solidified America as a nation by the end of the nineteenth century. ${ }^{, 66}$ Other scholars argue that we

\footnotetext{
${ }^{62}$ ANDRO LiNKLATER, THE FABRIC OF AMERICA: HOW OUR BORDERS AND BOUNDARIES SHAPED THE COUNTRY AND FORGED OUR NATIONAL IDENTITY 44 (2007).

${ }^{63}$ See generally Alan TAYlor, American Colonies: The Settling of North America (2002); see also David C. Hendrickson, Peace PaCt: The Lost World of the AMERICAN Founding (2003) (arguing that the Founding was a "peace pact" meant to stave off violent conflict among the states by creating a federal union similar to the interstate settlements that had existed among European countries); DAVID HaCKetT Fischer, Albion's SEED: Four British FolKWAYS IN AMERICA (1989) (exploring the origins of dramatic differences between colonial cultures in Puritan New England, aristocratic Virginia, the Quaker Delaware Valley, and the Scotch-Irish backcountry); Daniel J. Elazar, The American Mosaic, The Impact of Space, Time, and Culture on AMERICAN Politics 59 (1994) [hereinafter Elazar, Mosaic] ("British America's first generation saw an attempt to allow religious pluralism on a strictly territorial basis; that is, particular religious groups were given, or claimed, exclusive control over particular territories.”).

${ }^{64}$ Samuel P. Huntington, Who Are We? The Challenges to America's National IDENTity 17 (2004).

${ }^{65} \mathrm{Id}$.

${ }^{66}$ Id. See also Robert Penn WARRen, The Legacy of the Civil WAR 4, 6-7 (1961) (observing that "we became a nation ... only with the civil war" and that after it, the nation "gives us our most significant sense of identity").
} 
did not truly become a unified nation until the Second World War. ${ }^{67}$ In any event, "American nationalism became preeminent as the United States emerged on the world scene and in the following century fought two world wars and a cold war." ${ }^{\circ 8}$ One can hardly doubt that, as national identity increased in importance, state identity suffered at least a relative decline and, possibly, an absolute one as well. But to acknowledge this hardly demonstrates that the states have become identical and unimportant, or that state identity no longer remains strong enough to play an important role in our federalism.

Proponents of the One Nation argument would no doubt agree with Anthony Bourdain assertion that "now . . . the whole country looks like Jersey." ${ }^{69}$ But evidence of continued state distinctiveness and attachments is all around us. If one leaves behind the suburbs, it would be hard to claim that Newark feels like Austin, San Francisco, or even Manhattan, that the Jersey landscape resembles Yosemite, the Texas Panhandle, or the coast of Maine, or that people in Jersey are indistinguishable from the denizens of Laredo, Berkeley, or Wichita. Or consider the 2012 electoral season, which presented our federalism in all its fascinating (and frustrating) glory. During the interminable Republican primaries, each new state presented a radically different playing field, with a different correlation of political forces (e.g., evangelicals in South Carolina, Yankees and crossover voters in New Hampshire, Catholics in Pennsylvania), a unique set of salient issues (immigration in Texas and Arizona, abortion in Pennsylvania, ethanol subsidies in Iowa), and even styles of campaigning (door-to-door in New Hampshire, TV ad blitzes in Michigan and Florida). ${ }^{70}$ In the general election, the varied characteristics of each state profoundly shaped the electoral strategies of the candidates, and the outcomes in each state reflected considerable political divergence. ${ }^{71}$ Closer to home, I am continually surprised by the proportion of my Duke students avowing a strong attachment to North

\footnotetext{
${ }^{67}$ BARONE, supra note 48 , at 269 (observing that "over the next three generations [following the Civil War] the North and the South remained within the same national boundaries but lived largely apart from each other," but "World War II had an opposite, annealing effect").

${ }^{68}$ Huntington, supra note 64, at 17.

${ }^{69}$ Bourdain, supra note 3 , at 301 .

${ }^{70}$ [cites]

${ }^{71}$ [cites]
} 
Carolina - even at the private, more cosmopolitan rival of the state's flagship university in Chapel Hill. ${ }^{72}$

Recognizing that the plural of "anecdote" is not "data," we need a better factual basis for current discussions of state identity. State identity is neither easy to define nor easy to measure, and social scientists have long acknowledged that "[w]e have very little empirical data on the characteristics of political culture within American states." ${ }^{, 73}$ I do not purport to have solved either the definitional or the measurement problem here. But it is possible to move the ball forward on both fronts: We can be more precise about the various things we may mean when we talk about state identity, and that in turn will help us assess the several different sorts of evidence concerning whether it still exists and to what extent.

\section{A. Identity, Distinctiveness, and Political Culture}

The general problems of federalism, nationalism, and political loyalty are all very old, but use of the term "identity" in connection with such social questions is much more recent. ${ }^{74}$ One would like to begin with a cogent definition, but the term itself is both

\footnotetext{
${ }^{72}$ After all, a favorite canard slung about by Tarheel types is that Duke students all hail from-you guessed it-New Jersey. See, e.g., Natethegreat155, Why We (Still) Hate Duke, THESPORTSJURY.COM, Jan. 14, 2011, available at http://thesportsjury.com/cbb/why-we-still-hateduke/. Actually, North Carolina and California tied for the most students in the Duke undergrad class of 2016; New Jersey came in fifth. Duke University Office of News and Communications, Quick Facts about Duke, http://newsoffice.duke.edu/all-about-duke/quick-facts-about-duke (visited April 17, 2013). Although Duke has a higher New Jersey percentage, it is worth remembering that UNC has over twice as many New Jerseyan undergrads as Duke. Compare Profile of the Class of 2018, Duke Univ., http://admissions.duke.edu/images/uploads/process/DukeClass2018Profile.pdf (last visited Feb. 16, 2015) (93 New Jersey undergrads in the Class of 2018), with Student Headcount by State of Origin, Fall 2014, Univ. of N.C. (Sept. 16, 2014), http://oira.unc.edu/files/2014/09/StudentHeadcount-by-State-of-Origin-Fall-2014.pdf (197 New Jersey undergrads in the Class of 2018).

${ }^{73}$ Samuel C. Patterson, The Political Cultures of the American States, 30 J. Politics 187, 195 (1968).

${ }^{74}$ See Kwame Anthony ApPiah, The Ethics of Identity 65 (2005) ("The contemporary use of 'identity' to refer to such features of people as their race, ethnicity, nationality, gender, religion, or sexuality first achieved prominence in the social psychology of the 1950s-particularly in the work of Erik Erikson and Alvin Gouldner."); Rogers Brubaker \& Frederick Cooper, Beyond 'identity,' 29 THEORY \& SOCIETY 1, 2-4 (2000) (same). For a detailed etymology, see WiLliam
} 
ambiguous and controversial. William Mackenzie wrote in the mid-1970s that "identity" was a word "driven out of its wits by over-use"; ${ }^{75}$ more recently, Rogers Brubaker and Frederick Cooper have argued that "“[i]dentity” . . . tends to mean too much (when understood in a strong sense), too little (when understood in a weak sense), or nothing at all (because of its sheer ambiguity)., 76

The One Nation argument identifies identity as a precondition for federalism: Professor Feeley and Dean Rubin assert that "regional autonomy will only be appealing to people if the region itself is meaningful to people, that is, if it relates to their sense of political identity." 77 They seem to suggest, however, that only an exceptionally strong form of identity will do. The "attitudinal criteria" for federalism are not met, they assert, unless people are "willing to die" and "willing[] to kill" in order "to establish a separate or quasi-autonomous regime." ${ }^{78}$ Certain fringe movements aside, ${ }^{79}$ that level of commitment to state separatism surely died at Appomattox.

It is unclear why willingness to engage in separatist violence should be the criterion. In a less polemical moment, Professor Feeley and Dean Rubin recognized that "[p]olitical identity need not be universal, exclusive, or even primary in order to be an important determinant of people's attitudes." ${ }^{80}$ This weaker conception is far more

James Millar MacKenzie, Political Identity 19-27 (1978) (tracing the use of "shared identity" back to Aristotle).

${ }^{75}$ MACKENZIE, supra note 74, at 11.

${ }^{76}$ Brubaker \& Cooper, supra note 74, at 1.

${ }^{77}$ FEELEY \& RUBIN, supra note 14, at 16.

${ }^{78} I d$. at 61 .

${ }^{79}$ See, e.g., Simon Romero, In Small Town, the Fight Continues for Texas Sovereignty, N.Y. TiMES, Feb. 13, 2005, available at http://www.nytimes.com/2005/02/13/national/13overton.html. Indeed, in its current form, even the "Republic of Texas" movement may not meet the Feeley/Rubin criteria. See id. (suggesting that the organization has entered a "kinder, gentler" phase).

${ }^{80}$ FEELEY \& RUBIN, supra note 14, at 11; see also id. (“'Political identity] need only be a means of self-interpretation that is readily and widely deployed in a variety of situations. That is sufficient for it to serve as an important consideration in virtually any political setting and as a determinative one in a good number of situations."); $i d$. at 50 (acknowledging "the complex, variable character 
consistent with discussions of identity in both public discourse ${ }^{81}$ and the social science literature ${ }^{82}$ than the violence-only notion. ${ }^{83}$ No one thinks that Scottish identity doesn't exist simply because modern-day Scots seem (mostly) unwilling to paint their faces blue and whack the English with claymores. ${ }^{84}$ Even in the wake of the Scottish secession referendum's defeat, distinctive Scottish identity and loyalty continues to have important political consequences. ${ }^{85}$

It will help to begin with Professor Mackenzie's elegant question, "in what context do 'I' properly use the word 'we'?" central to my present purpose: a notion of self-understanding as well as a sense of

of political identity," and noting that "[m]any people possess a dual identity or multiple identities or experience shifts from one identity to another").

${ }^{81}$ See, e.g., Natan Sharansky with Shira Wolosky Weiss, Defending Identity: Its INDISPENSABLE ROLE IN PROTECTING DEMOCRACY 7 (2008) (“The individual understands himself or herself in terms of a community, not only as a singular independent person but also as an individual attached to others and interdependent with them. . . Identity in this sense is a kind of communal self.").

${ }^{82}$ See, e.g., Thomas RisSE, A COMmunity of Europeans? Transnational IDENTities AND PUBLIC SPHERES 9 (2010) ("Social identities are collectively shared social constructions linking individuals to social groups, national or supranational imagined communities in our case.”).

${ }^{83}$ See, e.g., Brubaker \& Cooper, supra note 74, at 6-8 (discussing five different usages of "identity" among scholars, none of which are limited to willingness to engage in violence). Professors Brubaker and Cooper worry that "weak" formulations of identity both depart from "the common-sense meaning of the term," which typically connotes "strong notions of group boundedness and homogeneity," and may be "too weak to do useful theoretical work." Id. at 1011. But this concern has to with whether identity must necessarily entail an "emphasis on sameness over time or across persons," $i d$. at 10 , not whether identity must be sufficiently compelling to motivate violent behavior.

${ }^{84}$ See generally Ailsa Henderson, HiERARChiEs of Belonging: NATIONAL Identity AND Political Culture In SCOTLAND AND Quebec (2007).

85 See After the No Vote, The ECONOMIST, Sept. 19, 2014, http://www.economist.com/blogs/blighty/2014/09/scotlands-referendum-1 (discussing efforts "to crack on with the promised devolution" that the U.K. government assured Scotland would occur if it remained in the Union, and concluding that "the United Kingdom will stay united. But it will also be looser and constitutionally messier than in the past").

${ }^{86}$ MACKENZIE, supra note 74, at 12. 
commonality and connectedness. The first involves "one's sense of who one is, of one's social location, and of how (given the first two) one is prepared to act." ${ }^{87}$ The second connotes an "emotionally laden sense of belonging to a distinctive bounded group, involving both a felt solidarity or oneness with fellow group members and a felt difference from or even antipathy to specified outsiders." 88

This is all pretty fuzzy, however. My ultimate concern is with the institutional dynamics of federalism. I want to know, for example, whether Members of Congress can really be counted upon to protect the interests of their states as distinct political communities (as opposed to voting their ideology or maximizing their personal chance of re-election). ${ }^{89}$ Likewise, I seek to assess how likely a state's citizens are to display "loyalty," in Albert Hirschman's sense, as opposed to choosing "exit" when conditions head South. ${ }^{90}$ Martha Nussbaum has written that individuals cannot be expected to make sacrifices on behalf of their fellow citizens unless they feel "love" and communal attachment for the common political community; ${ }^{91}$ I want to find out whether any of that affection is left in the American states. Although Dean Rubin and Professor Feeley's criterion of "willingness to fight and die" is too extreme, they are right to ask what people are willing to do for their states. "Understood as a ground or basis of social action," Professors Brubaker and Cooper write, “'identity' is often opposed to 'interest' in an effort to highlight and conceptualize non-instrumental modes of social and political action." 92 Put simply, my question is whether contemporary Americans understand themselves as sufficiently attached to their state political communities for that attachment to make a difference in decisions that affect the federal structure. ${ }^{93}$

\footnotetext{
${ }^{87}$ Brubaker \& Cooper, supra note 74, at 17.

${ }^{88}$ Id. at 19; see also SHARANSKY, supra note 81, at 7 ("[I]dentity means identification: solidarity with others with whom you identify.").

${ }^{89}$ See, e.g., Wechsler, supra note 20.

${ }^{90}$ See Hirschman, supra note 21, at 36-38.

${ }^{91}$ See Martha C. Nussbaum, Political Emotions: Why Love Matters for Justice (2013).

${ }^{92}$ Brubaker \& Cooper, supra note 74, at 6 (emphasis in original).

${ }^{93}$ Again, Scotland provides a useful example. Scots did not identify strongly enough with Scotland, to the exclusion of their broader British identity, to secede. But Scottish identity was strong enough that Westminster had to make significant concessions of autonomy to stave off
} 
Multiple literatures address identity. An extensive literature on nationalism draws primarily on political science, history, and philosophy, ${ }^{94}$ and another voluminous body of work on aspects of multiculturalism, especially racial and ethnic identity, adds in cultural anthropology and social psychology. ${ }^{95}$ A comparative politics literature addresses identity as an aspect of international development, ${ }^{96}$ and a psychological literature addresses personal identity. ${ }^{97}$ I will emphasize the nationalism literature, because it is more closely attuned to questions of politics and governance, while borrowing some from other disciplines as well.

At the outset, one may well ask whether any of these literatures can appropriately be brought to bear on state identities within a federal system. Benedict Anderson famously defined a nation as "an imagined political community — and imagined as both inherently limited and sovereign." ${ }^{98} \mathrm{He}$ acknowledged, however, that "[i]n fact all communities larger than primordial villages of face-to-face contact (and perhaps even these) are imagined." If state communities in fact exist, then, they will be "imagined" in the same sense, and raise at least some of the same problems, as national communities.

The analogy might fail, however, along either of the dimensions that Professor Anderson identifies as crucial: the inherent limits or the sovereignty of the community. Perhaps states are too limited in scope to foster a distinctive state identity. But this seems

secession. The future of devolution in the U.K. will likely depend on whether that situation persists.

${ }^{94}$ See, e.g., Benedict Anderson, Imagined Communities (rev. ed. 2006); DAvid Miller, ON Nationality (1995); Nussbaum, love of Country, supra note 5; Anthony D. Smith, NATIONAL IDENTITY (1991).

${ }^{95}$ See, e.g., Appiah, supra note 74; Multicultural States: Rethinking Difference AND IDENTITY (David Bennett, ed.1998).

${ }^{96}$ See, e.g., Political Culture and Political Development (Lucian W. Pye \& Sidney Verba eds. 1969); see also MACKENZIE, supra note 74, at 29-34 (discussing this literature).

${ }^{97}$ See, e.g., Peter J. Burke \& JAN E. StETS, IDENTITY THEORY (2009).

${ }^{98}$ ANDERSON, supra note 94 , at 6.

${ }^{99}$ Id. 
unlikely, at least in the context of American federalism. As the map below demonstrates, the American states have populations equivalent to major nations around the world. ${ }^{100}$

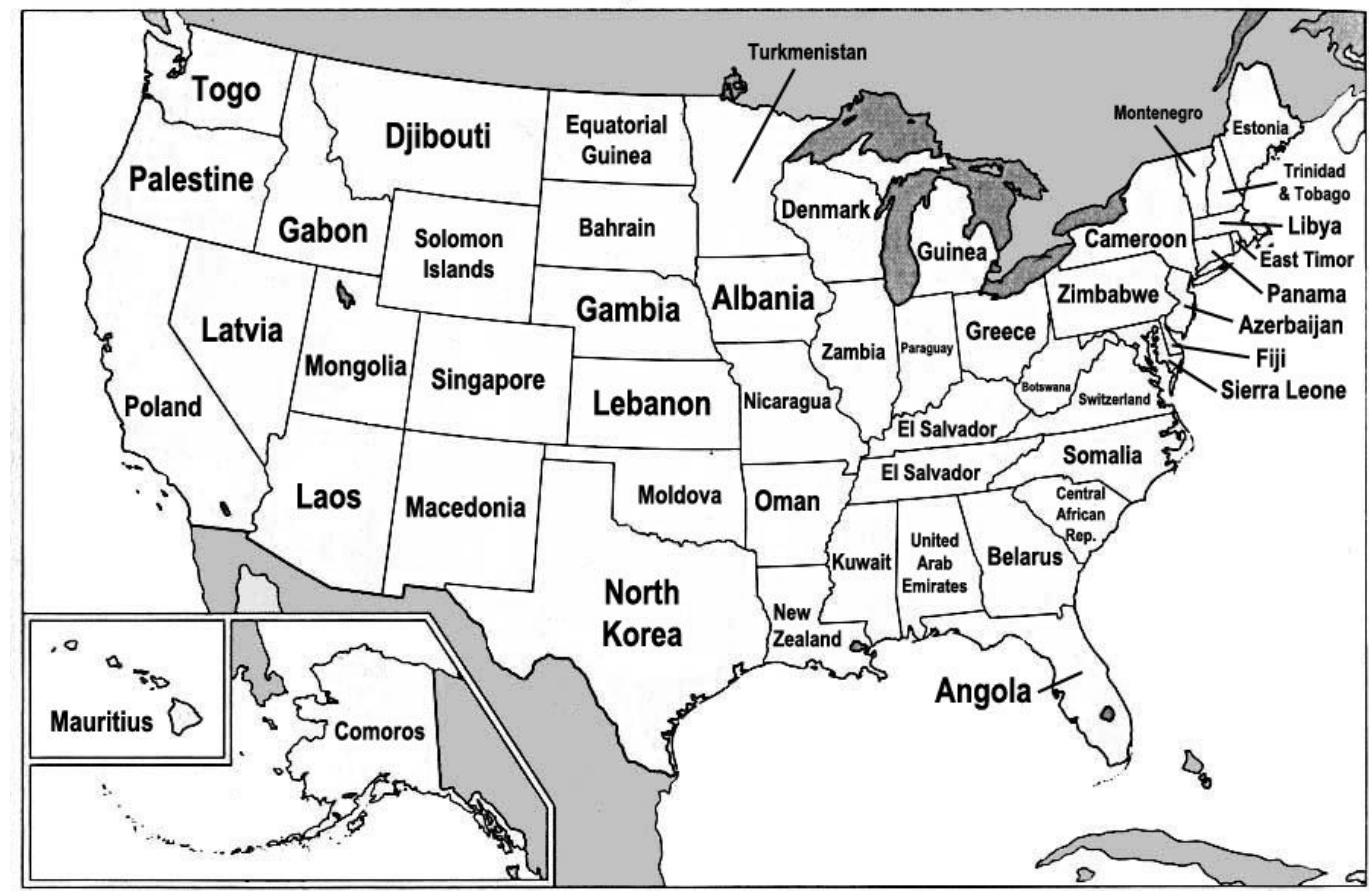

As a matter of scale, Ohio has a similar population to Greece, Oregon is the size of Palestine, and New Jersey has as many people as Azerbaijan. Neither Greece, Palestine, nor Azerbaijan seems to have found itself too small to have nationalists. ${ }^{101}$ Similar

${ }^{100}$ See Frank Jacobs, US States as Countries of Equal Population, Strange Maps, bigthink.com, June 6, 2009, available at http://bigthink.com/strange-maps/388-us-states-as-countries-of-equalpopulation (map depicts analogous countries by flag; full listing is in comment 36). For a similar map, using some different countries, see Stateside Substitutes: Comparing US States with Countries, THE ECONOMIST, Jan. 13, 2011, available at http://www.economist.com/blogs/dailychart/2011/01/comparing us states countries.

${ }^{101}$ Wyoming, our smallest state population-wise, has a comparable population to that of the Solomon Islands. See id. On nationalist movements within that island republic, see Solomon Islands, ENCYCLOPEDIA BRITANNICA, available at http://www.britannica.com/EBchecked/topic/553556/Solomon-Islands/53970/History\#ref513786 (visited Dec. 7, 2012) (describing "a nationalist movement known as Maasina Rule, which lasted from 1944 to $1952 ")$. 
comparisons can be made as a matter of physical size. New Jersey, for example, is slightly larger than Israel. ${ }^{102}$ The next map ${ }^{103}$ facilitates a vivid comparison of the size of well-recognized nation-states to American states:

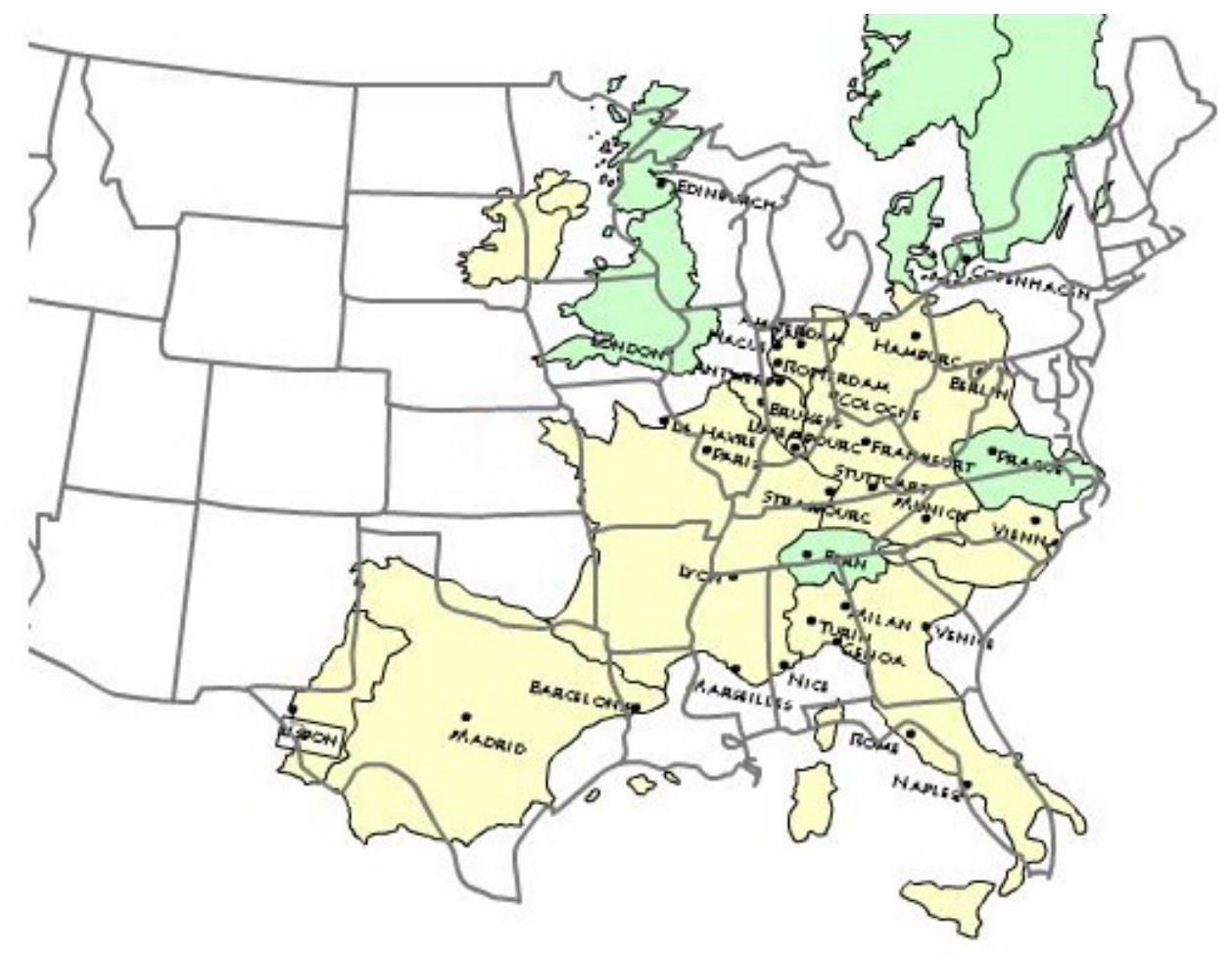

By either measure, then, that the American states are hardly too small to serve as objects of political identity.

${ }^{102}$ See Diana Hartman, Americans, Know Thy World: The Size of a Country (Part One: A-L), blogcritics, Feb. 15, 2007, available at http://blogcritics.org/culture/article/americans-know-thyworld-the-size/; see also How Big are the States in America?, wisegeek.com, http://www.wisegeek.com/how-big-are-the-states-in-america.htm (visited Dec. 7, 2012).

103 James Martin, Europe v. US Size Comparison Map, About.com, available at http://goeurope.about.com/od/europeanmaps/l/bl-country-size-comparison-map.htm (visited Dec. 7, 2012). My own sense of state identity compels me to point out that Texas is bigger than France. See id. 
What about sovereignty? In analyzing questions of political identity, we will do better to use "sovereignty" somewhat loosely. As David Miller points out, one of the main issues in debates about nationalism is "whether each nation has a right to its own state." 104 Hence, "'nation' must refer to a community of people with an aspiration to be politically self-determining, and 'state' must refer to the set of political institutions that they may aspire to possess for themselves." ${ }^{105}$ When we invoke Weber's concept of a "set of political institutions" that "successfully claims a monopoly of legitimate force in a particular territory"106 or Blackstone's older notion of a "a supreme, irresistible, absolute, uncontrolled authority, in which the jura summi imperii, or the rights of sovereignty, reside," ${ }^{107}$ we are generally talking about the state-that is, the institutions of government — not the underlying nation. ${ }^{108}$ The Palestinians have managed quite a bit of nationalism despite lacking, for much of their history, a set of state political institutions with control over a territory, and the member states of the European Union retain strong national identities despite having ceded far too much political authority to Brussels to be considered "sovereign" in the Blackstonian sense. ${ }^{109}$ Indeed, a prominent view in international relations theory redefines sovereignty as the ability to participate in

\footnotetext{
${ }^{104}$ MiLLER, supra note 94, at 19.

${ }^{105} I d$.

${ }^{106} I d$. (citing Max Weber).

1071 William Blackstone, Commentaries on the Laws of England *49 (Chicago, 1979) (1765).

${ }^{108}$ See, e.g., SMith, supra note 94, at 14 (distinguishing between "national identity" and a "conception of the state"); Francis Fukuyama, The Origins of Political Order: From Prehuman Times to the French ReVolution 12-17 (2011) (distinguishing between the state as a set of political institutions and the underlying society); PhiLIP BobBitT, THE SHIELD OF Achilles: War, PeAce, AND the Course of History 81 (2002) ("The modern state . . . is an entity quite detachable from the society that it governs as well as from the leaders who exercise power.").

${ }^{109}$ See generally ThOMAs Risse, A COMmUnity of EuRopeans? TRANSNATIONAL IDENTItiES AND PUBlic SPHERES 40-41 (2010) (collecting recent survey data); Anthony D. Smith, National Identity and the Idea of European Unity, 68 INT'L AFFAIRS 55 (1992); see also Ernest A. Young, The European Union: A Comparative Perspective, 1 OXFORD GUIDE TO EUROPEAN LAW (forthcoming 2015) [hereinafter Young, European Union] (discussing the persistence of Member State identity in Europe and its implications for European federalism).
} 
cooperative efforts at international governance that significantly limit autonomy, ${ }^{110}$ and historical scholarship demonstrates that many of the Founders thought of their new Union in precisely these terms. ${ }^{111}$

It thus seems possible to speak of nationalist-type identities in the American states despite the fact that those states lack a full measure of sovereignty. After all, the national government lacks full sovereignty, too; as Justice Kennedy has observed, "[t]he Framers split the atom of sovereignty."112 But this juristic reality has not prevented the development of nationalism in the United States. ${ }^{113}$ The fact that two governments share authority over any given patch of territory in this country certainly complicates American notions of political identity. Indeed, the central story of American history in the nineteenth and early twentieth century was the growth of an American national identity that could compete with, and eventually eclipse, the identification of Americans with their states. ${ }^{114}$ But the fact that state identity must coexist and possibly compete with other identities hardly renders it incoherent; after all, as Anthony Smith has observed, "the self is composed of multiple identities and roles-familial, territorial, class, religious, ethnic and gender." ${ }^{, 15}$ I return to this problem of competing national and state identities in some depth in Part VI. For present purposes, however, my point is simply

\footnotetext{
${ }^{110}$ See Abram Chayes \& Antonia Handler Chayes, The New Sovereignty: Compliance WITH INTERNATIONAL REGULATORY AGREEMENTS (1998).

${ }^{111}$ See HENDRICKSON, supra note 63, at 28 (arguing that the Founders considered "the making of the union and the Constitution to be an experiment in international cooperation").

${ }^{112}$ U.S. Term Limits, Inc. v. Thornton, 514 U.S. 779, 838 (1995) (Kennedy, J., concurring); see generally GORDON S. WOOD, THE CREATION OF THE AMERICAN REPUBLIC, 1776-1787 (1969) (discussing the Founders' views on sovereignty).

${ }^{113}$ See, e.g., Graham E. Fuller, America's Uncomfortable Relationship with Nationalism, Stanley Foundation Policy Analysis Brief, July 2006, available at http://www.stanleyfoundation.org/publications/pab/pab06nationalism.pdf.

${ }^{114}$ See, e.g., Wilfred M. McClay, The Masterless: Self AND Society IN Modern AMERICA 9-39 (1994) (discussing the role of the Civil War in consolidating a national identity in America for people in the victorious North).

${ }^{115}$ SMITH, supra note 94 , at 4.
} 
that the American states' role as political subdivisions of a larger federal polity does not inherently disqualify them as loci for political identity. Ask any Québéçois. ${ }^{116}$

The difficulty in thinking of American states as objects of nationalist-type sentiment arises not from some categorical difference between those states and other political communities, but rather from a sense that our states lack the current linguistic or ethnic distinctiveness or the separate history that characterize a Quebec or a Scotland. ${ }^{117}$ I demonstrate in Part III that the homogeneity of our states has been exaggerated. Moreover, our history illustrates that ethnic homogeneity is not everything. As David Potter has pointed out, "[e]thnically, America has probably never shown a greater degree of sameness than at the time when the nation was dividing and moving toward civil war." 118 Nonetheless, it is not my thesis that any American state has developed a separate political identity on a par with the Québécois or the Scots. The question, rather, is whether individuals identify with their states in ways that meaningfully impact the working of our federal system. The literature on national identity is a helpful starting point in assessing that question.

David Miller's influential work on nationality offers five elements that, taken together, "serve to distinguish nationality from other collective sources of personal identity." 119 First, he argues, "national communities . . . exist when their members recognize one another as compatriots, and believe that they share characteristics of the relevant kind." ${ }^{120}$ Second, nationality "is an identity that embodies historical continuity." ${ }^{121}$ It is "a community of obligation. Because our forebears have toiled and spilt their blood to build and defend the nation, we who are born into it inherit an

\footnotetext{
${ }^{116}$ See, e.g., JAMES M. MCPHERSON, Is BLOOD THICKER THAN WATER? CRISES OF NATIONALISM IN THE MODERN WORLD (1998) (discussing Quebec's bid for autonomy as a crisis of nationalism).

${ }^{117}$ Cf. The Scottish Government, Scotland's Future-Your Guide to an Independent Scotland, http://www.scotreferendum.com/reports/scotlands-future-your-guide-to-an-independent-scotland/ (visited March 31, 2014) (website of executive branch of devolved Scottish government, making case for voting for independence in referendum scheduled for September 2014).

${ }^{118}$ DAVID M. POTTER, THE IMPENDING CRISIS, 1848-1861, at 8 (1976).

${ }^{119}$ MiLLER, supra note 94, at 27.

${ }^{120} I d$. at 22 .

${ }^{121} I d$. at 23.
} 
obligation to continue their work, which we discharge partly towards our contemporaries and partly towards our descendants." 122 Third, "national identity . . . is an active identity" defined "by the decisions that [the nation] takes." 123 This political component differentiates national and other forms of political identity from merely ethnic identity; as Anthony Smith explains, “"national' identity involves some sense of political community, however tenuous." ${ }^{24}$ Setting aside communities aspiring to have their own nations, like the Palestinians, "[a] political community in turn implies at least some common institutions and a single code of rights and duties for all the members of the community." $" 125$

"The fourth aspect of a national identity," Professor Miller argues, "connects a group of people to a particular geographical place." ${ }^{126}$ A nation is "a predominantly spatial or territorial conception," whereby "[t]he homeland becomes a repository of historic memories and associations, the place where 'our' sages, saints and heroes lived, worked, prayed and fought." ${ }^{127}$ Finally, "the people who share [a national identity] should have ... a common public culture." 128

This account of nationality emphasizes the civic aspects of national identitythat is, the idea of common political institutions, history, and ideals. It may be contrasted with "an 'ethnic' conception of the nation," distinguished by "its emphasis on a community of birth and native culture." "I29 In this ethnic conception-the volk, in German

${ }^{122} I$.

${ }^{123} I d$. at 24 .

${ }^{124}$ SMITH, supra note 94 , at 9.

${ }^{125}$ Id. For Smith, this "community of laws and institutions with a single political will" implies "a sense of legal equality among the members of that community." Id. at 10.

${ }^{126}$ Miller, supra note 94, at 24. See also id. at 25 ("It is this territorial element that has forged the connection between nations and states, since . . a state is precisely a body that claims legitimate authority over a geographical area.").

${ }^{127}$ SMITH, supra note 94 , at 9.

${ }^{128}$ MiLLER, supra note 94, at 24; see also SMITH, supra note 94, at 11 ("[N]ations must have a measure of common culture and a civic ideology, a set of common understandings and aspirations, sentiments and ideas, that bind the population together in their homeland.").

${ }^{129}$ SMITH, supra note 94, at 11; see generally id. at 12 ("Geneology and presumed descent ties, popular mobilization, vernacular languages, customs and traditions: these are the elements of an 
parlance ${ }^{130}$ - "the place of law in the Western civic model is taken by vernacular culture, usually languages and customs." ${ }^{, 131}$ It is important to recognize, however, that "[i]n fact every nationalism contains civic and ethnic elements in varying degrees and different forms." 132

We might also contrast civic nationalism with what Jurgen Habermas and others have called "constitutional patriotism"- a form of identity predicated exclusively on certain common political ideals, such as a commitment to basic human rights. ${ }^{133}$ Proponents of this view have urged, for example, that the disparate nationalities of the European Union may find a viable sense of collective political identity by emphasizing their commitment to human rights and other "European values." 134 Civic nationalists have argued, on the other hand, that constitutional patriotism is too thin-that it neglects

alternative, ethnic conception of the nation, one that mirrored the very different route of 'nationformation' travelled by many communities in Eastern Europe and Asia and one that constituted a dynamic political challenge."). Professor Smith calls the civic account "the standard, Western model of the nation," in contrast with a "non-Western model" that "sprang up . . . notably in Eastern Europe and Asia." Id. In order to avoid any debates about whether Germany, for example, counts as "the West"-as a native of West Texas, I'm not even sure Houston counts as "the West"-I will use the "civic" and "ethnic" terminology.

130 See, e.g., "People" in German: Leute-Menschen-Volk, ABOUT.CoM, http://german.about.com/library/weekly/aa021206a.htm, visited March 31, 2014 (distinguishing between three words for "people" in German; "volk" is used "when speaking of people as a nation, a community, a regional group, or 'we, the people."”).

${ }^{131}$ SMITH, supra note 94, at 12.

${ }^{132} I d$. at 13 (describing the French experience as an example); Graham E. Fuller, America's Uncomfortable Relationship with Nationalism, Stanley Foundation Policy Analysis Brief, July 2006, at 2-3, available at http://www.stanleyfoundation.org/publications/pab/pab06nationalism.pdf (pointing out that American nationalism has both civic and ethnic components). On civic and ethnic nationalism, see, e.g., Michael IgnATIEFF, Blood AND Belonging: Journeys INTO THE New NATiOnalism 5-9 (1993); Gardner, Southern Character, supra note 43, at 1282-87.

${ }^{133}$ See, e.g., Jürgen Habermas, Citizenship and National Identity: Some Reflections on the Future of Europe, 12 Praxis InT'L 1 (1992-93); Jan-Werner MÜller, CONSTITUTIONAl Patriotism (2007).

${ }^{134}$ [cites] 
common ties of culture and shared history that are necessary to flesh out and particularize a commitment to values that are universal in nature. ${ }^{135}$

Professor Miller's criteria, which broadly overlap with the emphases of other leading scholars on nationalism, fall into two broad categories: distinctive characteristics of the community (its geography, history, and culture), and attitudes held by its citizens (a sense of common connection and membership). I will use "distinctiveness" to describe the first category and confine "identity" to the second. Identity and distinctiveness are not necessarily related. After all, I identify strongly with my own family, even if Tolstoy was right that "[a]11 happy families are alike." ${ }^{136}$ Nonetheless, it seems plausible to hypothesize that persons may be more likely to identify with a state if they can meaningfully distinguish that state from other states. Much of the federalism literature (including state-identity skeptics like Dean Rubin and Professor Feeley) has assumed that identity is related to distinctiveness. In a search for meaningful proxies for state identity, state-by-state variation on political, social, demographic, and cultural matters seems at least relevant, if not conclusive. Moreover, certain phenomena seem likely to provide evidence of both: a distinctive political culture or artistic tradition, for example, not only helps distinguish one state from another but also develops only as a result of commitment by a significant subset of a state's citizens to focus on issues and themes particular to the state-level community.

Distinctiveness and identity play an important role with respect to two sets of concerns that permeate the literature on constitutional federalism. The first has to do with the virtues (and vices) of federalism, ${ }^{137}$ while the second involves federalism's preservation. These two sets of concerns may help us sharpen what we are looking for when we speak of state "distinctiveness" and "identity."

${ }^{135}$ See MiLLER, supra note 94, at 162-63. It may not be quite fair to charge constitutional patriots with neglecting these more particular elements entirely. See, e.g., MÜLLER, supra note 133, at 10 ("Political agency ... as envisaged by the proponents of constitutional patriotism, has been conceived as animated by a set of universalist norms, but enriched and strengthened by particular experiences and concerns."). Nonetheless, the two approaches differ in emphasis.

${ }^{136}$ LeO TOLSTOY, ANNA KARENIN 13 (Rosemary Edmonds, trans. 1978) (1873-1877).

${ }^{137}$ See, e.g., Barry Friedman, Valuing Federalism, 82 MINN. L. REV. 317 (1997); Michael W. McConnell, Federalism: Evaluating the Founders' Design, 54 U. CHI. L. REv. 1484 (1987); 


\section{B. Distinctiveness, Identity, and the Ends of Federalism}

The Iraqi Constitution created a federal system precisely because "Iraq is a country of multiple nationalities, religions, and sects." ${ }^{138}$ In the terms I have been using, Iraq was composed of subunits that had highly distinctive histories and cultures, religious and ethnic composition, and political preferences, and many Iraqis strongly identified with these subunits. From the standpoint of the One Nation argument, Iraq was a paradigm case of a country that needs federalism: Iraq's combustible mixture of religious sects and nationalities could be contained only by allowing each subgroup to have its own way on points of disagreement between the disparate communities, and by satisfying the need for recognition frequently voiced by distinctive cultural and political communities. ${ }^{139}$ As I have already discussed, proponents of the One Nation argument see this scenario as the only one warranting a federal solution. ${ }^{140}$

The question, however, is not whether a society would be ungovernable without federalism, but rather simply whether federalism will make a society better off. It is not difficult to see that more conventional accounts of the values of federalism also rely on notions of state distinctiveness and/or identity. Consider, for example, the argument that at least some kinds of policy are best made on a decentralized basis so that they can be more closely tailored to local preferences and conditions. As Michael McConnell has explained, "[s]o long as preferences for government policies are unevenly distributed among the various localities, more people can be satisfied by decentralized decision making than by a single national authority." ${ }^{\prime 41}$ This only works, however, if the states are at least somewhat distinctive in the sense that they feature different distributions of preferences than the nation as a whole. The same thing is true when we speak of tailoring policy not to local preferences, but to conditions; efforts at pollution control, for example, may be more successful where they can be chosen or adapted on the basis of local climate, population density, hydrological conditions, and the like. ${ }^{142}$ The only difference

\footnotetext{
138 Iraqi Const., Section One, art. 3 (available at http://www.uniraq.org/documents/iraqi_constitution.pdf).

${ }^{139}$ See, e.g., MiLLER, supra note 94, at 149 (discussing demands for recognition).

${ }^{140} I d$.

${ }^{141}$ McConnell, supra note 137, at 1493.

${ }^{142}$ See, e.g., Friedman, supra note 137, at _ ; DAVID L. ShaPiro, Federalism: A Dialogue
} (1995). 
is that here the important kind of distinctiveness lies not in diverse policy preferences of the citizenry but in the physical or demographic characteristics of the local environment.

While both versions of this argument for policy diversity depend on some level of state distinctiveness, neither hinges on identity. In Professor McConnell's example, nothing turns on whether the good citizens of State A or B care about or identifies with their home jurisdiction. It is enough that the states are distinctive in some way - that they have distinct conditions or qualities or simply contain diverse correlations of political forces. ${ }^{143}$ Identity may play a somewhat more important role, however, in other standard arguments for federalism.

Consider, for example, the argument that federalism permits beneficial policy competition among the states. As Professor McConnell states the argument, "smaller units of government have an incentive, beyond the mere political process, to adopt popular policies. If a community can attract additional taxpayers, each citizen's share of the overhead costs of government is proportionately reduced." ${ }^{\prime 44}$ For my purposes, two things are worth noting about this argument. First, nothing depends on the states being distinctive in some profound historic or cultural sense; if we had fifty identical state jurisdictions, competitive pressures might well encourage them to offer divergent policies in order to attract more citizens and capital. The distinctiveness that matters here is that states have the opportunity to develop distinctive policies and, more fundamentally, that state governments are responsive to their citizens' preferences.

Second, identity may play an important role in facilitating interstate competition. We might ask, for example, why the citizens pressing for more competitive policies within their state have not simply moved to a more competitive state themselves? In Professor Hirschman's terms, state citizens who advocate competitive policy innovations are exercising "voice" rather than "exit," and the decision to do so often relies on a third factor: "loyalty." "145 The kind of identity that matters, then, is the sort of attachment that

\footnotetext{
${ }^{143}$ See also Bulman-Pozen, supra note 16, at _ (emphasizing the diversity of political predominance under federalism while denying that states are distinctive or intrinsic objects of loyalty).

${ }^{144}$ McConnell, supra note 137, at 1498.

${ }^{145}$ HIRSCHMAN, supra note 90 , at
} 
may press citizens to support policy change within their home jurisdiction rather than simply seeking greener pastures somewhere else. ${ }^{146}$

Similar points can be made about arguments for federalism based on the value of state-level policy experimentation-Justice Brandeis's famous vision of the states as "laboratories of democracy." 147 The type of distinctiveness that matters is not the initial conditions of the states but rather their willingness and opportunity to try divergent policy approaches to common problems. ${ }^{148}$ But the willingness and ability of states to conduct policy experiments at all depends, as just noted, on having citizens that identify sufficiently with the state to remain in place and work for reform rather than exercising their rights of exits when unfavorable conditions arise. On the other hand, both the competition and experimentation rationales also trade on some degree of exit - that is, on a subset of the population being willing to move. That mobility, after all, incentivizes competition and rewards successful experiments. These aspects of federalism may work best when some subset of a state's population is sufficiently loyal to remain in place and work for reform, but another significant subset is mobile and ready to exit in search of better conditions elsewhere. State identity, in other words, need not be universally shared.

A second set of federalism values stems not from policy diversity but from the ways in which federalism may enhance the operation of the political system as a whole. These include citizen participation in politics, which is often thought to be easier at the state and local level, ${ }^{149}$ and voluntary compliance with the law, which is more likely when the local population had a hand in making that law and feels that it reflects their preferences. ${ }^{150}$ To the extent that majority preferences in a particular state diverge from the nation as a whole, federalism permits "dissenting by deciding"; if national dissenters

\footnotetext{
${ }^{146}$ See, e.g., Young, Federalism Strategies, supra note 27, at _.

${ }^{147}$ See New State Ice Co. v. Liebmann, 285 U.S. 262, 311 (1932) (Brandeis, J., dissenting).

${ }^{148}$ To the extent that states are deeply distinctive, however, that fact may undermine the value of one state's successful experiment to other states, as it may be unclear that the successful prototype can be adapted to divergent conditions in other jurisdictions.

${ }^{149}$ See, e.g., Gregory v. Ashcroft, 501 U.S. 452, 458 (1991); Deborah Jones Merritt, The Guarantee Clause and State Autonomy: Federalism for a Third Century, 88 Colum. L. Rev. 1, 78 (1988).

${ }^{150}$ See McConnell, supra note 137, at 1508.
} 
control a state government, after all, they have the opportunity not only to voice their arguments but also to enact them into law. ${ }^{151}$

Most important among this latter group of federalist virtues is the ability of states to check central power. ${ }^{152}$ Although the days in which the state might oppose national power militarily may be behind us, ${ }^{153}$ states also serve important checking functions within the sphere of democratic politics. Throughout our history, state governments have provided a rallying point for opposition to national policy. ${ }^{154}$ State legislatures may issue protests against unconstitutional or otherwise illegitimate national action, ${ }^{155}$ direct their own officials not to cooperate in the enforcement of federal law (or to enforce it differently than federal policy mandates), ${ }^{156}$ file lawsuits challenging national policy, ${ }^{157}$

${ }^{151}$ See Gerken, Dissenting by Deciding, supra note 51; see also Bulman-Pozen, supra note 16, at ; Ernest A. Young, Welcome to the Dark Side: Liberals Rediscover Federalism in the Wake of the War on Terror, 69 BROOKLYN L. REV. 1277, 1286-87 (2004).

${ }^{152}$ See generally Young, Taft Lecture, supra note 7, at

${ }^{153}$ See Rubin \& Feeley, supra note 28, at

${ }^{154}$ See Vicki C. Jackson, Federalism and the Uses and Limits of Law: Printz and Principle, 111 HARV. L. REV. 2180, 2218 n.177 (1998) (noting that "Rubin and Feeley's argument . . . ignores the degree to which the political structures of state and local governments provide organizing points for the development and maintenance of political opposition to the national government").

${ }^{155}$ See, e.g., James Madison, Report on the Resolutions (1800), reprinted in 6 THE WritingS OF JAMES MADISON 341 (Gaillard Hunt ed., 1906) (articulating Virginia's and Kentucky's opposition to the federal Alien and Sedition Acts). ; see also Jackson, supra note 154, at 2219 n.181 (noting that "states are structurally better protected from federal overreaching than any discrete group of individuals, even a political majority, because their existing organization facilitates political action").

${ }^{156}$ See, e.g., Ann Althouse, The Vigor of Anti-commandeering Doctrine in Times of Terror, 69 BROOKLYN L. ReV. 1231 (2004) (discussing state and local noncooperation with the Patriot Act); Michael Boldin, Liberty Preservation: The states say 'NO' to NDAA, TENTH AMENDMENT CENTER, April 8, 2013, available at http://tenthamendmentcenter.com/2013/04/08/libertypreservation-the-states-say-no-to-ndaa/ (reporting on Virginia legislation and pending bills in California, Michigan, Montana, and Texas to prohibit state agencies from supporting the indefinite detention provisions of the 2012 National Defense Appropriations Act).

${ }^{157}$ See, e.g., Ernest A. Young, Popular Constitutionalism and the Underenforcement Problem: The Case of the National Healthcare Law, 75 L. \& ConTEMP. Probs. 157, 198-99 (2012) 
or simply take the lead in legislative reform where the national government has failed to do so. ${ }^{158}$

None of these process values is likely to be fully realized if the states are not distinctive from one another or if citizens do not identify, at least somewhat, with their states. The distinctive correlation of political forces in any given state is one of the spurs to popular participation; it gives political parties an incentive to mobilize support stateby-state rather than focusing on the national level. ${ }^{159}$ And dissenting by deciding by national minorities is only possible if a state has a different profile from not only the nation but from other states. Likewise, individual states are most likely to act as a political check on the center if they diverge from national norms.

Identification and loyalty may play an even more critical role. As Professor Hirschman noted, loyalty "activates voice"; that is, felt attachments to one's home community encourage discontented citizens to stay and work for reform rather than simply to exit. ${ }^{160}$ When the going gets rough, citizens' self-identification as loyal members of a state political community may be a key to ensuring that the state retains the resources necessary to recover and reform. This kind of loyalty may also encourage the sort of communal action and compromise necessary to overcome political disagreement; as George Fletcher puts it, "loyalty is the beginning of political life, a life in which interaction with others becomes the primary means of solving problems." 161 Selfidentification with a particular state may even encourage citizens who disagree with

(discussing the role of States in opposing federal policies such as the Affordable Care Act); Merritt, supra note 149, at 5 (noting that states are "indefatigable litigants").

${ }^{158}$ See, e.g., Gordon S. WOOD, EMPIRE OF LiBERTY: A History of THE EARLy REPUBLIC, 17891815 , at 520 (" $[\mathrm{B}] \mathrm{y}$ the early nineteenth century every Northern state had provided for the eventual end of slavery."); Merritt, supra note 149, at 6-7.

${ }^{159}$ See Bulman-Pozen, supra note 16, at _..

${ }^{160}$ HiRsCHMAN, supra note 90, at 78 .

${ }^{161}$ George P. Fletcher, Loyalty: An EsSAy on the Morality of Relationships 5 (1993); see also Gabriel A. Almond \& Sidney Verba, The Civic Culture 246 (1963) ("The attitude most relevant to long-term political stability may not be the individual's level of satisfaction with governmental out-put or with his role as participant" but rather "a more diffuse sense of attachment or loyalty to the political system-a loyalty not based specifically on system performance"). 
particular state policies to nonetheless feel an investment in them ${ }^{162}$-a result that may facilitate both compromise and political reform. I have argued elsewhere, for example, that proponents of same-sex marriage are most likely to achieve lasting social acceptance if they prevail legally through channels that opponents perceive as legitimate and democratic; having "had their say," opponents may well be more likely to accept the results. $^{163}$

States are also more likely to be effective checks on the central government if they enjoy the loyalty of their citizens. Writing about national identity, Sidney Verba argued that "[i]t is the sense of identity with the nation that legitimizes the activities of national elites and makes it possible for them to mobilize the commitment and support of their followers." 164 Commenting on this passage, Samuel Patterson observed that "[s]ystem identification, pride, commitment, and loyalty may be associated with political sub-systems as well," and he concluded that "[i]n a federal structure, the states are likely to constitute important focuses for identification, loyalty, and pride." 165 This was evidently the view of our Founders, who viewed federalism as a competition between the national and state governments for the loyalty of the sovereign People. ${ }^{166}$ More contemporary conceptions of the "political safeguards" of federalism ultimately rest on the same premise. ${ }^{167}$ As I discuss further in Part VI, the Federalists envisioned Americans identifying with both their national and state governments, with each level of loyalty becoming more salient to the extent that the other level performed poorly or presented a threat to liberty. ${ }^{168}$ State identities thus need not be exclusive or even

${ }^{162}$ See, e.g., Morton Grodzins, The Loyal AND the Disloyal 21 (1956).

${ }^{163}$ See Young, Federalism Strategies, supra note 27, at

164 Sidney Verba, Comparative Political Culture, in Political Culture And Political DEVELOPMENT, supra note 96, at 512, 529.

${ }^{165}$ Patterson, supra note 73 , at 191, 198.

${ }^{166}$ See, e.g., The Federalist Nos. 45 \& 46 (James Madison); Pettys, supra note 23; see generally Jacob T. Levy, Federalism, Liberalism, and the Separation of Loyalties, 101 Am. POL. SCI. ReV 459 (2007).

${ }^{167}$ See generally Wechsler, supra note 20; see also Ernest A. Young, Two Cheers for Process Federalism, 46 VILL. L. REV. 1349, 1356-57 (2001) (discussing the relation between Wechsler's theory and the ability of states to attract the loyalty of their citizens).

${ }^{168}$ See infra notes ____ and accompanying text. 
primary; rather, a healthy federalism simply requires that each level of government enjoy sufficient loyalty to maintain popular support, develop and implement distinctive politics, and — in a pinch—channel popular dissent from national policy.

Loyalties to states are critical not only to preserving liberty, but also to preserving federalism itself. For decades, legal scholars and jurists have debated whether constitutional limits on national power require judicial enforcement for their preservation; the alternative, as Herbert Wechsler famously put it, is to rely on "political safeguards"chiefly, the states' representation in Congress - to safeguard the institutional autonomy of state governments. ${ }^{169}$ More recent entries into this debate have expanded the scope of "political safeguards" to include, for example, the role of state political parties and autonomous behavior by state bureaucrats charged with implementing federal law and state lobbying efforts in Washington, D.C. ${ }^{170}$ These institutional mechanisms seem unlikely to function well, however, unless the state representatives and officials involved identify strongly with their native jurisdictions. Put in Albert Hirschman's terms, ${ }^{171}$ the political safeguards of federalism offer the states an avenue for "voice," but voice will often be ineffective unless it is supported by "loyalty."

If all this is right, then the "One Nation" argument errs by assuming that accommodating strong and discordant state identities is the only purpose or end of federalism. The federalist virtues of policy diversity and experimentation, participatory politics, and checks and balances have value whether or not citizens strongly identify with their states; they thus offer reasons to care about-and seek to preserveconstitutional federalism even if it could be shown that strong state identities no longer exist. But I have suggested that these virtues are unlikely to persist or be effective without both state distinctiveness and some measure of citizen identity with and loyalty to the states. We should think of identity, then, as an important means of sustaining federal

${ }^{169}$ Compare, e.g., Wechsler, supra note 20; JeSSE H. CHOPER, JUdicial REviEW AND THE National Political Process: A Functional Reconsideration of the Role of the Supreme COURT _ (1980); Kramer, supra note 55 (all arguing that judicial review should be minimal or nonexistent), with Lynn A. Baker \& Ernest A. Young, Federalism and the Double Standard of Judicial Review, 51 Duke L. J. 75, 106-33 (2001); Saikrishna Prakash \& John Yoo, The Puzzling Persistence of Process-Based Federalism Theories, 79 TEX. L. REV. 1459 (2001) (each arguing that "political safeguards" are incomplete).

${ }^{170}$ See, e.g., Bulman-Pozen \& Gerken, supra note 56; NugENT, supra note 55.

${ }^{171}$ HIRSCHMAN, supra note 21. 
structures that we may value for other reasons. If we care about the structural values of federalism, we need the states to be robust and distinctive political communities in their own right. Concerns that state identity may be waning — if not dead already — thus present a threat to important constitutional values.

\section{Looking for Political Community in the States}

For over half a century, the Member States of the European Union have been pursuing a grand experiment in "ever closer union." 172 That project presents a puzzle for students of federalism. Most observers agree that "[t]he scope of Community activity is now so broad that few if any areas of national policy are immune from its effects." yet the EU is generally perceived to be far less centralized than the United States. ${ }^{174}$ What factors maintain the EU's relatively decentralized equilibrium in the absence of strong constraints on Brussels' legislative powers?

Part of the answer plainly has to do with identity: Most Europeans continue to perceive themselves primarily as Germans, Frenchmen, and Poles rather than Europeans. ${ }^{175}$ The European experience suggests that culturally distinct communities within a polity do play an important role in sustaining the constitutional autonomy of the decentralized political units to which they are attached. New Jersey, in other words, might well be more independent of the national political establishment in Washington, D.C. if it had its own volk. But what if it doesn't? If Colonel Robert E. Lee had been a

\footnotetext{
${ }^{172}$ The phrase is from the preamble to the Treaty of Rome (1957). See generally LuUK VAN Middelaar, The Passage to Europe: How a Continent Became a Union (2013).

${ }^{173}$ Gareth Davies, Subsidiarity: The Wrong Idea, in the Wrong Place, at the Wrong Time, 43 Common MKт. L. Rev. 63, 63 (2006); see generally Young, European Union, supra note 109, at

${ }^{174}$ See, e.g., Andrew Moravcsik, The European Constitutional Settlement, in SOPHIE MEUNIER \& KATHLEEN R. MCNAMARA, EDS., MAKING History: EuROPEAN INTEgRATION AND InStitutional ChANGE AT FifTy, 23, 24 (2007); see also Young, European Union, supra note 109 , at

${ }^{175}$ See, e.g., VAN MidDELAAR, supra note 172, at 217; Hartmut Kaelble, Identification with Europe and Politicization of the EU Since the 1980s, in JEFFREY T. CHECKEL \& PETER J. KATZENSTEIN, EDS., EUROPEAN IDENTITY 193, 205-08 (2009) (surveying evidence that national allegiances remain primary); Smith, supra note 109, at
} 
citizen of contemporary New Jersey, is it even conceivable that he would have preferred his state allegiance to his national one?

Most American legal academics think not. Certainly, the conventional wisdom is that (a) the states of contemporary America are fundamentally similar to one another; and (b) contemporary Americans feel little or no attachment to those states. But is there any way to test these propositions? The only serious effort occurs in James Gardner's work on state constitutionalism, which is directed against some state courts' tendency to interpret their state constitutions in light of Professor Gardner emphatically rejects this notion on the ground that "Americans are now a people who are so alike from state to state, and whose identity is so much associated with national values and institutions, that the notion of significant local variations in character and identity is just too implausible to take seriously as a basis for a distinct constitutional discourse." 176 Several other prominent scholars have likewise argued that state courts cannot draw on distinctive constitutional traditions, ${ }^{177}$ but only Gardner has made any effort at all to support the claim that state identity does not exist. ${ }^{178}$

Because they represent the only effort in the legal literature to actually support assertions about the death of state identity, Professor Gardner's arguments are worth considering in some detail. He makes three claims. The first two rest on "the most

${ }^{176}$ Gardner, Failed Discourse, supra note 43, at 818.

${ }^{177}$ See, e.g., Robert A. Schapiro, Identity and Interpretation in State Constitutional Law, 84 VA. L. REV. 389, 393 (1998) [hereinafter Schapiro, State Constitutional Law] (arguing that "[t]he community model ... represents a questionable understanding of state identity and gives rise to pointless, indeed oftensilly, debates about state character"); Paul W. Kahn, Interpretation and Authority in State Constitutionalism, 106 HARV. L. REV. 1147, 1149-50 (1993) [hereinafter Kahn, State Constitutionalism] (observing that "[b]ecause public life is experienced in and through the national community, we typically find little sympathy for a local community's effort to maintain a unique public identity," and concluding that "[i]f states are no longer the locus of a vibrant, community experience, then a state constitutionalism that looks to the unique state community for its sources of decisionmaking promises to remain a marginal factor in American public life").

${ }^{178}$ Professors Schapiro and Kahn and each treats the death of state identity as largely self-evident; at best, they cite a unifying factor or two which might be thought to nationalize the culture, see, e.g., Kahn, State Constitutionalism, supra note 177, at 1150 (citing "the emergence of a national army"), without producing any evidence that these factors actually have that effect or outweigh other factors, such as distinctive geography, economic conditions, religious beliefs, or migration patterns, that might push in the other direction. 
glaringly obvious features of modern American society: the ease and frequency of mobility; [and] the dominance of mass media and mass marketing of national scope." ${ }^{, 179} \mathrm{I}$ address mobility in some depth in Part IV, but the basic point is that American mobility is not, in fact, more frequent than in prior eras; moreover, as mobility becomes easier, it is more likely to have a sorting effect that increases the coherence and distinctiveness of state communities. ${ }^{180}$

As for media and marketing, it is true that the literature on nationalism and identity places considerable emphasis on common media discourse. But President Obama recently lamented that "the balkanization of the media means that we just don't have a common place where we get common facts and a common worldview the way we did 20, 30 years ago." 181 Professor Gardner's contrary assertion rests primary on concentrated ownership in the newspaper and television markets, but these sources hardly dominate news or discourse in the Internet Age. Likewise, Gardner's cites the dominance of large suburban shopping malls as fostering a unitary consumer culture. ${ }^{182}$ That business model

${ }^{179}$ GARDNER, supra note 15 , at 69 . Gardner also mentions "the increasing globalization of economic activity," id., although he does not pursue the point. Any argument from globalization would prove too much, as globalization supposedly renders not only subnational but national borders irrelevant - and Gardner does not claim that our national political community has become obsolete. In any event, Gardner ignores literatures in both comparative federalism and international relations demonstrating how globalization and supranationalism, by weakening the nation state, may free subnational units to play a more important role. See, e.g., Christopher K. Connolly, Independence in Europe: Secession, Sovereignty, and the European Union, 24 DuKE J. Comp. \& INT'L L. 51 (2013); Earl H. Fry, The U.S. States and Foreign Economic Policy: Federalism in the 'New World Order,' in Foreign Relations and Federal States 122 (Brian Hocking ed. 1993). Certainly no one can plausibly argue that globalization - whatever one means by that term - has made the Scots or the Catalans less distinctive.

${ }^{180}$ See infra Section IV.C.

${ }^{181}$ Obama: The Vox Conversation, Vox, Jan. 2015, available at http://www.vox.com/a/barackobama-interview-vox-conversation/obama-domestic-policy-transcript. See also Terence P. Jeffrey, Obama Blames 'the Balkanization of the Media,', CNSNEWS.COM, Nov. 15, 2013, available at http://cnsnews.com/news/article/terence-p-jeffrey/obama-blames-balkanization-media. What is "CNSNews.com," you ask? It's web-based "alternative news source" founded by political conservatives. See cnsnews.com/about-us. Vox, on the other hand, is an influential website run by the liberal blogger Ezra Klein. This is what the President was talking about.

${ }^{182}$ GARDNER, supra note 15, at 71-72 (citing Bernard J. Frieden \& LyNNE B. SAGALyn, Downton, InC.: How AMERICA RebUilds Cities 69 (1989)). 
is in decline, ${ }^{183}$ and internet marketing makes extremely specific targeting of individual shoppers a preferable alternative to Gardner's account of one national marketing conversation. ${ }^{184}$ All quibbling aside, however, the real problem with both arguments is Gardner's failure to demonstrate that the development of a common national culture has crowded out distinctive state political cultures.

Professor Gardner's main argument does address state identity directly—after a fashion. In a companion article, he points out that "if any part of the nation in any period might be expected to have displayed a distinct character and set of values, it would be the antebellum and Confederate South"; nonetheless, "[a]s a matter of historical fact, according to historians who study the South, any differences between the South and North in culture, character, or values were . . too slight by far to support contemporary impressions" of regional distinctiveness. ${ }^{185}$ It is, of course, a bit odd to try and disprove the existence of distinctive state identities today by reference to a society that existed a century-and-a-half ago. Moreover, Gardner's assertion is highly implausible. He relies on sources demonstrating that the Confederate states may not have been as different from the North as they (and their subsequent apologists) liked to suppose, but these sources hardly conclude that the differences were not meaningful. ${ }^{186}$ Gardner's position that the

${ }^{183}$ Malls are so nineties. See, e.g., Once Temples of American Commerce, Indoor Malls Lose Shoppers to E-stores, PBS NEwSHOUR, Nov. 28, 2014, at http://www.pbs.org/newshour/bb/temples-american-commerce-indoor-malls-lose-shoppers-estores/ ("Indoor malls have been in decline ever since consumers discovered online shopping, and many retail spaces are either closing or being repurposed as shopping habits evolve."); Amy Merrick, Are Malls Over? THE NEW YORKER, Mar. 11, 2014, at http:/www.newyorker.com/business/currency/are-malls-over (suggesting that large malls are being replaced by smaller shopping areas integrated with residential and public space).

${ }^{184}$ See, e.g., James D. Ratliff \& Daniel L. Rubinfeld, Online Advertising: Defining Relevant Markets, 6 J. COMP. L. \& ECON. 653 (2011).

${ }^{185}$ Gardner, Southern Character, supra note 43, at 1290-91; see also GARDNER, supra note 15, at 72-74 (repeating this argument).

${ }^{186}$ For example, Gardner cites C. Vann Woodward's conclusion that the South "remains more American by far than anything else, and has all along," C. VANN WoOdWARD, THE Burden OF SOUTHERN HistORY 25 (1960) (cited in Gardner, Southern Character, supra note 43, at 1236). But Professor Woodward's argument in that essay was that the South had a unique historical experience that had shaped its character in such a way as to allow it to make a special contribution to the nation. WOODWARD, supra, at 15-25. In fact, the same paragraph Gardner quotes concludes that " $[\mathrm{t}]$ he modern Southerner . . should be secure enough also not to deny a regional heritage 
South was not (and therefore is not) distinctive enough to matter legally or politically flies in the face of overwhelming scholarly consensus. ${ }^{187}$

Critically, the Confederate South meets even the overly-restrictive identity critera set by Dean Rubin and Professor Feeley - that is, willingness to "fight and die" for a subnational community. ${ }^{188}$ Even if Professor Gardner were right that the Old South was not so distinctive, that would simply prove the Anna Karenina principle that distinctiveness is not a necessary condition for identity. Perhaps distinctiveness is the more critical factor for Gardner's argument about state constitutionalism; ${ }^{189}$ his focus, after all, is on whether state legal traditions are sufficiently different to justify interpreting textually-similar state constitutional provisions in divergent ways. But for my purposes, it is identity that principally matters. The evidence Gardner cites is a useful corrective for

because it is at variance with national myth. It is a heritage that should prove of enduring worth to him as well as to his country." Id. at 25; see also Eugene D. GenOvese, The Southern Tradition: The AChiEvement and Limitations of an AMERican Conservatism (1994) (likewise arguing that the South has a distinctive political tradition with something to offer the nation). The leading contemporary historian of Southern identity reaches a nuanced conclusion that southern identity is both individual in focus and not the same thing as distinctiveness; he nonetheless observes that "I have yet to encounter anyone who has moved into or out of the South and did not have the sense that, for better or worse, living here was different from living in other parts of the country." James C. COBB, Away Down South: A History OF SOUTHERn IDENTITY 336-37 (2005). This is all we need to reject the various formulations of the One Nation argument. See also Gardner, Southern Character, supra note 43, at 1233 (conceding that "historians and social scientists who study the South uniformly agree that the South is distinct in some way, to some degree").

${ }^{187}$ See, e.g., KEY, supra note 269, at 1 ("[T] character and tradition.").

${ }^{188}$ See supra notes ___ a and accompanying text.

${ }^{189}$ One of Gardner's key points is that Southern identity rests on an exaggerated notion of Southern distinctiveness, and that this notion has been constructed for political purposes. See Gardner, Southern Character, supra note 43, at 1252 (stating that this is cause for viewing "contemporary beliefs about Southern distinctiveness . . . with a certain skepticism"). But the literature on nationalism has long accepted that national identities are socially constructed and not simply reflections of reality. See, e.g., E.J. HobSBAwM, NATIONS AND NATIONALISM SINCE 1789: Programme, Myth, Reality 10 (1990) (observing that nations are "constructed essentially from above"); ANDERSON, supra note 94, at 6 (noting that nations are "imagined" communities). That does not make those identities inconsequential. 
Confederate apologists' claims that the antebellum South was an entirely separate and unique society. But it cannot tell us anything useful about state identity today.

That's all there is. No one in the legal literature-or, to my knowledge, anywhere else-has made any broad-gauged evidence-based effort to determine Important arguments and judgments are being made not only throughout the academic literature but also in constitutional litigation based on assumptions about distinctiveness and identity without any kind of actual knowledge of the facts. This, simply put, is an intolerable state of affairs.

Parts III and IV of this essay develop contemporary evidence about the distinctiveness of the states' and their citizens' sense of state identity, respectively. Part III offers up a smorgasbord of facts, trivia, and Americana about the States - their physical characteristics, demographic makeup, economic conditions and performance, and political culture. It turns out that people who think the states are all the same may be spending too much time drinking coffee at Starbucks, eating at Cheesecake Factory, and watching network television. They need to get out more, because the States are in fact quite different places from one another.

Identity, loyalty, and attachment are much harder to get empirical purchase on. Part IV begins with the efforts states make to construct a common history and impart that history to the next generation. I then consider public opinion research not on state identity per se, but on public trust in the various levels of government, as well as preferences for national or state action on particular questions. I then consider the extent to which people move from one jurisdiction to another over the course of their lives, dispelling the myth that our society is "increasingly mobile" and demonstrating that the mobility we do have may actually strengthen rather than undermine state identity.

\section{State Distinctiveness}

Can we really tell one state from another anymore? In his essay on New Jersey, Anthony Bourdain recounts an experience from a book tour,

waking up in Austin or Minneapolis or St. Louis, at yet another anonymous chain hotel. Not knowing where I was, I threw open the drapes and looked out the window, desperate for orientation. Where was I? . . . Beneath me, an endless and grimly predictable sequence of Victoria's Secret superstore, McDonald's, the Gap, P. F. Chang's, T. G. I. Friday's, Chili's, Home Depot. Mall after mall separated only by a 
strip mall or min-mall, stretching out to the horizon, where another glasscovered cityscape clustered perhaps around a shopping district. I could have been anywhere. I could have been in New Jersey. ${ }^{190}$

Many of us have had similar impressions. We've all had the experience, for example, of finding a Starbucks on every corner whether one is in Boston or Austin.

These perceptions are not always accurate, however. It turns out that although both Massachusetts and Texas are Starbucks-rich, a significant "latte gap" exists between those jurisdictions and states like West Virginia, Mississippi, and Vermont, which must suffer along with only a tenth as many Starbucks outlets per person as in the franchise's home state. ${ }^{191}$ Similarly, many observers invoke "the spectre of a homogenized landscape, the endless suburbs, strip developments and Wal-Marts and box stores," 192 but Arkansas and Oklahoma actually enjoy seven times as many Wal-Marts per person as bargain-deprived jurisdictions like New York, New Jersey, and California. ${ }^{193}$ If even this widespread perception of the homogeneity of American consumer culture masks more regional variation than we might expect, then we might also question the more fundamental intuition that all the states are the same. ${ }^{194}$

One recent empirical study of state politics concluded that "[s]tates have real, significant cultural and political differences. And despite the homogenizing tendencies of national media, drastically lower transportation costs, and a franchised consumer economy, regional political differences have not gone away." 195 Academics in the field of

${ }^{190}$ Bourdain, supra note _, at 307.

${ }^{191}$ GELMAN, supra note 49, at 29; see also id. at 30 (with a map!).

192 David Goldblatt, The Independent, Dec. 12, 2008, available at http://www.independent.co.uk/arts-entertainment/books/reviews/state-by-state-a-panoramicportrait-of-america-edited-by-matt-weiland-and-sean-wilsey-1062480.html (visited March 18, 2011) (reviewing STATE BY STATE, supra note 3).

${ }^{193}$ GELmAN, supra note 49, at 29. Anecdotally, a casual survey of auto license plates in the parking lot at the West Lebanon, New Hampshire Wal-Mart (on the Vermont border) suggests that the Wal-Mart gap is a significant spur to interstate travel.

194 See also FlowingData, Grocery Store Geography, June 26, 2013, available at http://flowingdata.com/2013/06/26/grocery-store-geography/ (mapping the highly regional distribution of major grocery store chains).

195 GELMAN, supra note 49, at 21-22. 
comparative state politics tend to view these matters quite differently from "One Nation" proponents. Virginia Gray, for example, ascribes the continued existence of American federalism to "the magnitude of state differences": "The states are so different it is hard to imagine they would get along within a single government. Only federalism could accommodate the cultural distance between, say, clean-living Utah and gambling-mecca Nevada. Federalism allows these differences to flourish." ${ }^{196}$

I collect several different types of evidence in this Part. Some of it is data in the social science sense: survey responses, or statistics on demographics, mobility, or political behavior. Some of it is cultural - that is, anecdotal reporting by literary authors and other cultural elites. ${ }^{197}$ To the extent that we are trying to measure culture, I have included this latter form of evidence despite its "soft" nature. If an artist like Bruce Springsteen thinks New Jersey is both distinctive and lovable, ${ }^{198}$ that has an effect on the culture notwithstanding that the Boss himself is hardly a typical datapoint.

This Part begins with "policy inputs"-that is, the geographical, demographic, economic, and cultural facts creating the environment and imperatives that shape state policy. I then turn to "policy outputs"-the actual decisions that state governments make, as reflected in state constitutions, other state laws, and general state policy choices. All of this information admittedly has a "glass half full/glass half empty" quality to it: The States are different, but perhaps they are not that different. One might as well admit

${ }^{196}$ Virginia Gray, The Socioeconomic and Political Context of States, in POLITICS IN THE American States: A Comparative ANALYsis 1, 6 (Virginia Gray \& Russell L. Hanson, eds., $8^{\text {th }}$ ed. 2004). Legal commentators have largely ignored a fairly robust social science literature on state political culture. See, e.g., Daniel ElaZAr, American Federalism: A VieW from the States (3d ed. 1994) [hereinafter ElaZAR, AMERICAN FEDERALISM] (tracing influence of three distinct political cultures in the states); Elizabeth Adell Cook, Ted G. Jelen, \& Clyde Wilcox, State Political Cultures and Public Opinion About Abortion, 46 POL. RES. Q. 771, 771 (1993) (“A wellestablished literature points to important political differences between various American states.”).

${ }^{197}$ See, e.g., TheSe United StATES 2003, supra note 61; THESE United STATES 1920s, supra note 58; JOHN GUNTHER, InSIDE U.S.A. (50th Anniversary ed. 1997) (1947).

${ }^{198}$ See, e.g., Bruce Springsteen, Greetings from Asbury Park, NJ (Columbia Records, 1973); see also Lester Bangs, Bruce Springsteen: Greetings from Asbury Park, NJ, Rolling STONe, July 5, 1973 (album review), available at http://www.rollingstone.com/music/albumreviews/greetings-fromasbury-park-nj-19730705 ("Old Bruce makes a point of letting us know that he's from one of the scuzziest, most useless and plain uninteresting sections of Jersey.”). 
up front that no one has any idea how different the states need to be in order to sustain a healthy federal system - if we even had a general metric to measure "different" or "healthy" in the first place. But the federalism literature has focused on sameness for so long that it may help simply to review the other side of the ledger. At the end of the day, the States are different enough to lead this observer to suspect that Mr. Bourdain's vision of a relentlessly generic mercantile landscape may have been, well, just a bad trip.

\section{A. How Different are the States? Policy Inputs}

The banner of the Texas state tourism website insists that Texas is "like a whole other country." 199 "[T] $]$ he fact is," as Molly Ivins put it, "it's a damned peculiar place.,"200 But how distinctive are the American states, really? The Texas tourism website is, after all, selling something, and James Gardner has observed that "[a]11 too often arguments about the unique character and values of the people of a given state resemble nothing so much as chamber-of-commerce-style boosterism. "201 To be sure, we do not have a state, like Quebec within Canada, that speaks a different official language. Scholars of nationalism have emphasized the importance of a distinctive language in shaping national identity, ${ }^{202}$ but the same scholars have also made clear that a distinct language is not

\footnotetext{
${ }^{199}$ Office of the Governor, Economic Development and Tourism, www.TravelTex.com (visited Oct. 16, 2012),

${ }^{200}$ Molly Ivins, Texas: Texas on Everything, in THESE United STATES 2003, supra note _, at $421,421$.

${ }^{201}$ Gardner, Southern Character, supra note 43, at 1225. But see infra notes _-_ and accompanying text (demonstrating the profound influence of boosterism on the social construction of Texas state history and identity).

${ }^{202}$ See ANDERSON, supra note 94, at 37-46; see also Sujit Choudhry, Managing Linguistic Nationalism Through Constitutional Design: Lessons from South Asia, 7 I CON 577 (2009) (discussing the complex relationship between language and federalism in India).
} 
essential for the development of separate political identity. ${ }^{203}$ And if one looks past official languages, the states are more linguistically diverse than one might think. ${ }^{204}$

State comparativists begin with a variety of socioeconomic factors "that may affect patterns of state policy," such as "population size and composition, migration and urbanization, physical characteristics and natural resources, types of economic activities stemming from a state's physical endowments, wealth, and regional economic forces."205 This section begins with the obvious-empirical differences in geography, population and demographic makeup, and economic conditions - then moves to differences in history, political culture, and positions on public issues. Some of the differences are unsurprising, although some readers may be struck by their magnitude; others may be unexpected. The point of the section is simple: The States of the Union are more different than many people seem to think.

\section{The Land}

Long before Larry Bird and Gene Hackman stamped Indiana as the land of basketball underdogs, ${ }^{206}$ Theodore Dreiser grounded the essential and distinctive

${ }^{203}$ See ANDERSON, supra note 94, at 47 ("[W]hether we think of Brazil, the USA, or the former colonies of Spain, language was not an element that differentiated them from their respective imperial metropoles. .. . [L]anguage was never even an issue in these early struggles for national liberation.").

${ }^{204}$ The percent of the population speaking languages other than English at home varies from under 5 percent in Alabama, Mississippi, Kentucky, and West Virginia to over 40 percent in California and around 35 percent in New Mexico and Texas. See Language Spoken at Home by State: 2011, Statistical Abstract of the United States 2014, at 50 (2014) [hereinafter Statistical ABSTRACT]. Over a decade ago, the two leading Democratic candidates for Governor of Texas conducted a televised debate in Spanish. See Kelley Shannon, Texas Candidates Debate in Spanish, MidLAND DAILY NEWS, March 1, 2002, available at http://www.ourmidland.com/import/texas-candidates-debate-in-spanish/article_e2b8f754-93fc$52 \mathrm{c} 0-8 \mathrm{cc} 0-\mathrm{a} 364 \mathrm{c} 455 \mathrm{a} 68 \mathrm{e} . \mathrm{html}$. And linguists have documented extensive differences in the "English" spoken in different parts of this country. See, e.g., Walter Hickey, 22 Maps that Show Americans Speak English Totally Differently from One Another, Bus. InSIDER, June 5, 2013, available at $\mathrm{http} / / / \mathrm{www}$.businessinsider.com/22-maps-that-show-the-deepest-linguistic-conflictsin-america-2013-6?op=1.

${ }^{205}$ Gray, supra note 196 , at 6 .

${ }^{206}$ See Indianapolis Star News, ED., LARRy Bird: An Indiana Legend (1998); Hoosiers (1986) (starring Gene Hackman), at IMDb, http://www.imdb.com/title/tt0091217/; see also Dana 
character of his native state in "her soil and light." ${ }^{207}$ Hoosiers are not alone in stressing the distinctiveness of the physical environment. Lousie Erdrich described "[t]he North Dakota sky as "[s]hattering, spectacular, inescapable . . . a former tallgrass prairie heaven tarp that stretches down on every side and quiets the mind." 208 On a winter's visit to New Hampshire, Will Blythe discovered "that there are at least forty varieties of silence." 209

Notwithstanding the tendency of American constitutional law to think of political communities exclusively in terms of people, ${ }^{210}$ physical features-size, climate,

O'Neil, Basketball Means More in Indiana, ESPN.com, Jan. 31, 2013, available at http://espn.go.com/mens-college-basketball/story//id/8896650/basketball-touches-life-all-levelsindiana-college-basketball ("In Indiana, it is the gyms defined by the hanging of a basketball goal - hung majestically at Assembly Hall, where IU plays, or simply on the side of a silo- that connect the state."); Associated Press, Indiana's Christian Watford hits 3-pointer at buzzer to stun No. 1 Kentucky, Dec. 10, 2011, available at http://espn.go.com/ncb/recap?gameId=313440084; Richard Lingeman, Indiana: The Home State, in THESE United STATES 2003, supra note 61, at 133, 136 ("In my day, every little village had a team and a school gymnasium, and every garage or barn had a basketball hoop affixed to it. Now the village high schools have vanished, and the kids are bused to consolidated schools. But you still see the hoops.”). The 2014 Final Four lacked an Indiana team but was nonetheless a festival of American federalism, as the Universities of Florida, Wisconsin, Connecticut, and Kentucky squared off for the NCAA championship. See C.L. Brown, Like this season, Final Four won't be boring, March 30, 2014, available at http://espn.go.com/ncb/notebook/_page/homecourt140330/home-court.

${ }^{207}$ Theodore Dreiser, Indiana: Her Soil and Light, in THESE UNITED STATES 1920s, supra note 58, at 120 . Some eighty years later, Richard Lingeman wrote that " $[\mathrm{m}] \mathrm{y}$ final Indiana memory is of driving through countryside on a summer evening — faded red barns and white farmhouses, green rolling fields thick with corn, lit by the slangting golden light of the setting sun. There is such an aura of peace and fat contentment in that picture. That's my Indiana home, I guess. Or was." Lingeman, supra note 206, at 141.

${ }^{208}$ Louise Erdrich, North Dakota, in STATE BY STATE, supra note 3, at 349, 352.

${ }^{209}$ Will Blythe, New Hampshire, in STATE BY STATE, supra note 3, at 288, 297. Mike Barnicle, on the other hand, infamously commented that "New Hampshire looks like Arkansas with snow." Mike Barnicle, Vermont vs. New Hampshire, Boston Globe [date], reproduced at http://boulter.com/nh/barnicle.html.

${ }^{210}$ See, e.g., Reynolds v. Sims, 377 U.S. 533, _ (1964) ("Legislators represent people, not trees or acres."). 
topography, natural resources-may have significant influence on the character and culture of a state. As Jim Gardner points out, "[t]he idea that geography and climate influence national character" goes back at least to Montesquieu and Aristotle. ${ }^{211}$ Several historians have suggested that the land and climate went a long way toward creating the South's distinctive culture - and, in particular, its reliance on slavery. ${ }^{212}$

That the states differ in terms of these factors may be obvious; the magnitude of the differences, however, may retain some capacity to surprise. For instance, everyone knows that Alaska is really big, but it remains striking to learn that "the twenty-two smallest states could be combined before an area as large as Alaska is reached." ${ }^{213}$ Alaska is something of an outlier, but wide disparities persist as we move down the size rankings: The fifth largest state (New Mexico) is over fifteen times as large as the fortyfifth largest state (Massachusetts), and the tenth largest (Oregon) is over three times as large as the fortieth (South Carolina). ${ }^{214}$ As Professor Gray points out, geographic size does matter for politics and policy in a variety of salient ways: The size of rural districts and the distances legislators must travel to the capital affects how often a legislature can meet and who can afford to serve, for example, and per capital expenditures on highway infrastructure (a central responsibility of state governments) are wildly higher in Alaska and Wyoming than in Rhode Island. ${ }^{215}$

More profoundly, the land shapes political culture over time. David Hackett Fischer has traced, for example, the influence of New England's climate, highly variable weather, soil, and coastline on the development of Puritan culture, concluding that " $[\mathrm{t}] \mathrm{he}$ vitality of this regional culture owed much to its physical setting." ${ }^{216}$ T.R. Fehrenbach has likewise chronicled the influence of the Texas physical environment-in particular, the exposure of the frontier to hostile Indians and Mexicans, as well as the agricultural and

${ }^{211}$ Gardner, Southern Character, supra note 43, at 1229.

212 [cites]

${ }^{213}$ Gray, supra note 196, at 15.

${ }^{214}$ See CQ's State Fact Finder 2007, at 84 (2007) (listing the land areas of New Mexico (121,356 square miles), Oregon (95,997 square miles), South Carolina (30,110 square miles), and Massachusetts ( 7,840 square miles)). Just for fun, Alaska (571,951 square miles) is over 547 times as big as Rhode Island (1,045 square miles). Id.

${ }^{215}$ Gray, supra note 196 , at 15 .

${ }^{216}$ FISCHER, supra note 63, at 50-54. 
mineral resources that spurred the development of a fundamentally extractive economyon Texas history and political culture. ${ }^{217}$ One could proliferate additional example, but the point is simple: American political culture cannot help but respond to the immense diversity of the American physical environment.

\section{Demographics and Social Capital}

If we turn from land to people, we find similarly striking differences. The largest state, California $(35,458,000$ people in 2006) is seventy times as large as the smallest, Wyoming (515,000 people); the fifth largest, Illinois (12,832,000 people) is fifteen times the size of Delaware (853,000 people), the forty-fifth largest; and my own North Carolina $(8,857,000$ people), the tenth largest state, is almost seven times as large as the fortieth state, Maine $\left(1,322,000\right.$ people). ${ }^{218}$ Interestingly, the population data shows a large gap between the top four very large states (California, Texas, New York, and Florida) and the next group (Illinois, Pennsylvania, and Ohio); the gap between Florida and Illinois is roughly the size of Wisconsin, itself the twentieth largest state. ${ }^{219}$

We can expect population to affect state political culture in myriad ways, including national power (voting strength in the House of Representatives and the Electoral College), burdens on infrastructure and public services, and racial, ethnic, religious, and political diversity. These factors are driven not only by objective size, of course, but also by population growth, density, and demographic makeup. The states differ significantly along each of these lines. The fastest growing states in 2005-Nevada and Arizona - grew at approximately three times the rate of Virginia (ranked $16^{\text {th }}$ ) and seven times the rate of Iowa (ranked $36^{\text {th }}$ ); three states (Massachusetts, New York, and Rhode Island) found themselves actually losing population. ${ }^{220}$ The densest state, New Jersey, had 1,175 persons per square mile in 2005, while Alaska had only one, Wyoming

${ }^{217}$ T. R. Fehrenbach, Lone Star: A History of TeXas And the TeXans _ ( $2 \mathrm{~d}$ ed. 2000); see also Robert A. CAro, The Years of Lyndon Johnson: The Path to Power 8-32 (1982) (describing how geography, and particularly the quality of the soil, shaped the culture of the Texas Hill Country).

${ }^{218}$ CQ's STATE FACT FindeR, supra note 214, at 18.

${ }^{219}$ Florida had $18,090,000$ people in 2006, while Illinois had 12,832,000 and Wisconsin had 5,557,000. CQ's STATE FACT FINDER, supra note 214, at 18.

${ }^{220}$ CQ's STATE FACT FindeR, supra note 214, at 20. 
had five, and Kansas (ranked fortieth) had $34 .{ }^{221}$ It is not hard to see how these sorts of differences could cash out into quite different ways of life.

Demographically, the states differ along lines of age, race, education, economic, and religious indicators. On the input side, the 2004 birth rate in Utah was twice that of Maine and Vermont, ${ }^{222}$ while California welcomed nearly ten times as many legal immigrants in 2005 as tenth-place Washington (and 723 times as many as last place Wyoming) ${ }^{223}$ The median age of state populations range from 41.2 in Maine to 28.5 in Utah; the median states are Maryland and South Carolina at 37.1. ${ }^{224}$ In Florida, almost 17 percent of the population is over age 65; in Texas, Georgia, Utah, and Alaska, less than 10 percent is. ${ }^{225}$ In Utah, 30 percent of the population is 17 years old or younger, but only 21 percent of the population is that young in North Dakota, Vermont, West Virginia, and Maine. ${ }^{226}$

These disparities obviously have important cultural, economic, and political repercussions; for instance, Texas - which ranks in the top five for birth rates, legal and unauthorized immigration, and population under age 17, and eighth for percentage growth, is also in the top five states for the percentage of children living in poverty. ${ }^{227}$

${ }^{221}$ CQ'S STATE FACT FINDER, supra note 214, at 38.

${ }^{222}$ CQ's STATE FACT FINDER, supra note 214, at 36 (stating that, in 2004, Utah had a birth rate of 21.2 per 1000 population, while Vermont and Maine each had a rate of 10.6). Similarly, fourthranked Texas admitted five times as many legal immigrants as fourteenth-ranked Arizona. Id. Disparities in unauthorized immigrant populations are similarly marked. California's was estimated at 2.5 to 2.75 million in 2005 , with 1.4 to 1.6 million in second-ranked Texas; the median states were Indiana and Iowa, with 55 to 85 thousand apiece; and eight states (Alaska, Wyoming, South Dakota, Maine, Vermont, North Dakota, Montana, and West Virginia) had less than ten thousand. Id. at 40 .

${ }^{223}$ CQ's State Fact Finder, supra note _-, at 39. See also Laura B. Shrestha \& Elayne J. Heisler, The Changing Demographic Profile of the United States, CRS Report for Congress No. 7-5700, Sept. 25, 2009, at 12 ("The primary destination states in 2008, as in every year since 1971, were California, New York, Texas, Florida, Illinois, and New Jersey. Sixty-three percent of all (legal) persons immigrating to the United States in 2008 lived in these six states.”).

${ }^{224}$ CQ'S STATE FACT FINDER, supra note 214, at 26.

${ }^{225}$ CQ's STATE FACT FINDER, supra note 214, at 24.

${ }^{226}$ CQ's STATE FACT FINDER, supra note 214, at 25.

${ }^{227}$ CQ's STATE FACT FINDER, supra note 214, at 34. 
Youngish Utah has almost three times as many roller coasters per capita as oldish West Virginia, and the latter state leads the nation in toothlessness. ${ }^{228}$ The aging of populations figures prominently into assessments of the future economic and political prospects for countries around the world, ${ }^{229}$ and it is hard to imagine why the same factors would not be equally important to the several states.

One area of marked and persistence divergence is religion. "Since colonial times the adherents of the various religious traditions and groups in America have not been randomly distributed across the country." 230 These geographic patterns of religious belief "shape public cultures in different parts of the country and in turn are shaped by them." 231 As Professor Gelman notes, "Americans as a whole are strikingly observant . . . but states vary widely in this respect, with much higher church attendance in Mississippi and elsewhere in the deep South compared to states such as New Hampshire, Vermont, and Nevada."232 The religious profiles of various states are significantly different, althoughUtah aside — not massively so. Massachusetts, New York, New Jersey, and California are Catholic strongholds, with Catholics composing from 30 to 40 percent of the population in those states. ${ }^{233}$ Mainline Protestants have their largest concentrations (26 percent to 34 percent) in Wisconsin, Minnesota, and Pennsylvania. ${ }^{234}$ The Baptists enjoy disproportionate numbers (36 percent to 39 percent) in Tennessee, North Carolina, and Georgia, while the "Nones"- people registering no religious belief-have their highest

${ }^{228}$ See STATE By StATE, supra note 3, at 552 (table 18), 557 (table 23).

${ }^{229}$ See, e.g., Edmund Conway, UK's Aging Population is a Bigger Threat than the Financial Crisis, THE TelegraPH, Feb. 12, 2010, available at http://www.telegraph.co.uk/finance/financialcrisis/7216546/UKs-aging-population-is-a-biggereconomic-threat-than-the-financial-crisis.html.

${ }^{230}$ Barry A. Kosmin \& Ariela Keysar, Religion in a Free Market: Religious and NonReligious Americans, Who What Why Where 105 (2006); see also Gelman, supra note 49, at 79 ("Religion is inextricably tied to social and political geography. Different religions and denominations are concentrated in different parts of the country, from Mormons in Utah and Jews in New York to larger groups such as evangelical Protestants in the South and Roman Catholics in the metropolitan areas of the Northeast and Midwest.").

${ }^{231}$ KOSMIN \& KeYSAR, supra note 230, at 107.

${ }^{232}$ Gelman, supra note 49, at 130.

${ }^{233}$ Kosmin \& KEYSAR, supra note 230, at 114-15 \& Figure 7.7.

${ }^{234} \mathrm{Id}$. 
concentration (14 percent) in Washington State. ${ }^{235}$ All in all, recent survey data "conclusively confirms the continuing existence of some geographically specific religious subcultures within the nation.,"236

Finally, Robert Putnam's famous study of social capital in the United States included a comparative assessment of social capital in the fifty states. "Differences among the states on the underlying measures [that go into the Social Capital Index] are substantial," he found, "with ratios of roughly three to one between high- and lowranking states. Social trust, for example, ranges from 17 percent in Mississippi to 67 percent in North Dakota." 237 Professor Putnam's "barometer" of social capital revealed a clear geographical pattern:

The primary 'high-pressure' zone is centered over the headwaters of the Mississippi and Missouri rivers and extends east and west along the Canadian border. The primary 'low pressure' area is centered over the Mississippi Delta and extends outward in rising concentric circles through the former Confederacy. California and the mid-Atlantic states lie near the national average. ${ }^{238}$

As Putnam points out, these patterns correspond strongly not only to historical migration patterns but also to the states dominated by slavery in the nineteenth century and Jim Crow politics in the twentieth. ${ }^{239}$ "Inequality and social solidarity," he concluded, "are deeply incompatible. $" 240$

\footnotetext{
${ }^{235} I d$.

${ }^{236}$ Id. at $123-24$.

237 Robert D. Putnam, Bowling Alone: The Collapse and Revival of American COMMUNiTY 291 (2001).

${ }^{238}$ Id. at 292.

${ }^{239}$ Id. at 294.

${ }^{240} I d$. It may be worth noting, however, that the states with highest measure of income inequality - New York, Connecticut, and Massachusetts—all do fairly well on Putnam's social solidarity barometer. See List of U.S. States by Gini Coefficient, WIKIPEDIA, http://en.wikipedia.org/wiki/List_of_U.S._states_by_Gini_coefficient (visited Feb. 21, 2015).
} 


\section{State Economies}

In early 2013, Texas Governor Rick Perry went on a hunting trip — not in the Texas Hill Country, but in California. He was poaching jobs, using radio ads criticizing the difficulty of starting a business in California and in-person gubernatorial visits to promising California companies. ${ }^{241}$ The Governor's sales pitch emphasized Texas's lowtax, low-regulation economic model, which has placed Texas at or near the top of the fifty states in terms of GDP growth, job creation, as an alternative to California's model of progressive regulation, high taxes, and robust government services. ${ }^{242}$ Whatever one thinks of interstate job-snatching, Perry's trip dramatized the fact that the American states are large and competitive economic entities, confronting differing economic circumstances and employing diverse economic strategies.

Like the states' physical size and population, the economies of individual states also vary widely in size. California's GDP in 2012 was approximately $\$ 2$ trillion, while Wyoming's was only $\$ 38$ billion. ${ }^{243}$ The map below ${ }^{244}$ puts those numbers in perspective by relabeling each state with the name of a foreign country with a similar GDP.

\footnotetext{
${ }^{241}$ See Shan Li, Texas Gov. Rick Perry tries to woo California businesses, L.A. TIMES, Feb. 12, 2013, available at http://articles.latimes.com/2013/feb/12/business/la-fi-perry-jobs-20130213.

${ }^{242}$ See generally Dan Balz, Texas, California embody red-blue divide, WASH. Post, Dec. 28, 2013, available at http://www.washingtonpost.com/politics/texas-california-embody-red-bluedivide/2013/12/28/d6d4d7ee-6764-11e3-ae56-22de072140a2_story.html; California v. Texas: America's future, THE ECONOMIST, July 9, 2009, available at http://www.economist.com/node/13990207.

${ }^{243}$ Gross Domestic Product by State in Current and Chained (2005) Dollars: 2000 to 2012, in STATISTICAL ABSTRACT, supra note _, at 461.

${ }^{244}$ Frank Jacobs, US States Renamed for Countries with Similar GDPs, big think, June 10, 2007, available at http://bigthink.com/strange-maps/131-us-states-renamed-for-countries-with-similargdps.
} 


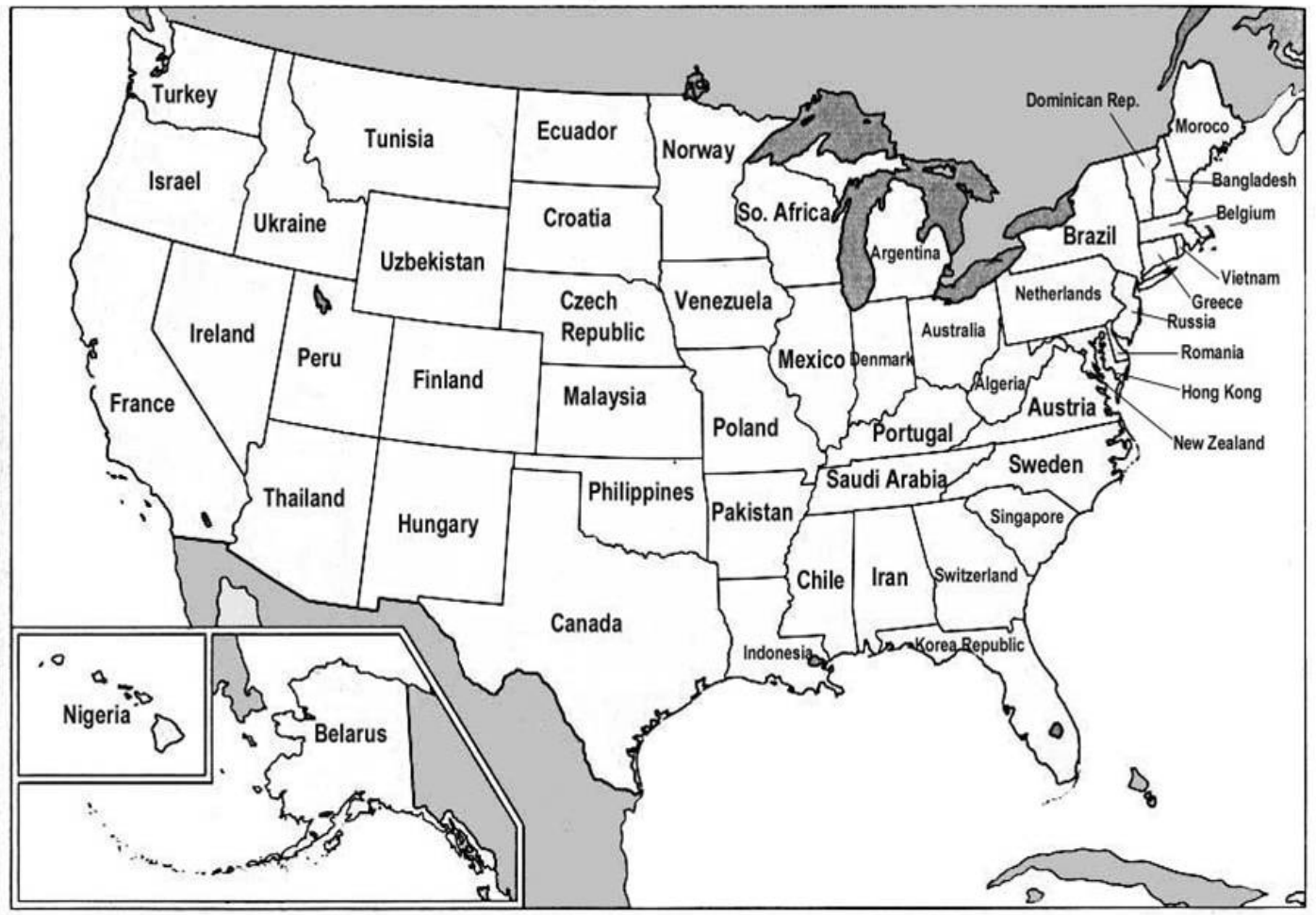

While it may not surprise to learn that California is economically equivalent to France or Texas to Canada, even many of the smaller states turn out to be comparable to significant foreign nations: Alabama has an economy the size of Iran's, for example, and Idaho is comparable to Ukraine. New Jersey's economy, strikingly, is about the same size as Russia's.

The evidence on economic conditions among the states is mixed: Differences in income and other leading indicators are significant, but hardly earth-shattering. The national average personal income per capita in 2012 was $\$ 42,693$, but that ranged from $\$ 33,073$ in Mississippi to $\$ 58,908$ in Connecticut. ${ }^{245}$ In 2011 , the national unemployment rate was 8.9 percent, but in the states unemployment ranged from under 6 percent in Iowa, Nebraska, New Hampshire, North and South Dakota, Vermont, and Wyoming to

${ }^{245}$ Personal Income Per Capita in Current and Chained (2009) Dollars by State: 1990 to 2012, in StAtistical Abstract, supra note _, at 468. Median family income varied from \$46,304 in Mississippi to $\$ 83,823$ in Maryland around a national average of $\$ 61,455$. See Family IncomeDistribution by Income Level and State: 2011, in STATISTICAL ABSTRACT, supra note _, at 472. 
over 11 percent in California, Nevada, and Rhode Island. ${ }^{246}$ According to the Minot mayor Curt Zimbelman, true unemployment in the North Dakota oil country "probably doesn't exist." ${ }^{, 247}$ These disparities provoke migration of both persons and businesses; in 2012, for example, it cost twice as much to rent a U-Haul truck one-way from California to Texas as it did to rent one going in the other direction. ${ }^{248}$

Poverty varied significantly as well. The national poverty rate in 2011 was 15.9 percent, but that varied from 8.8 percent in New Hampshire to 22.6 percent in Mississippi. ${ }^{249}$ The cheapest urban area in which to live appears to be Harlingen, Texas ( $81.8 \%$ of the national composite index); New York City's borough of Manhattan is the most expensive (225.4\% of the national index), followed by Brooklyn, New York $(178.6 \%)$ and Honolulu, Hawaii $(167.0 \%) .^{250}$

The performance of the various state economies over time also varies considerably. In 2012, the U.S. GDP grew by 2.5 percent overall. State GDP growth, however, varied from 13.4 percent in North Dakota to -0.1 percent in Connecticut. ${ }^{251}$ According to financial analyst Meredith Whitney, "[t]he strong growth of the central corridor [from Texas north to the Dakotas, and from Colorado east to Indiana] is being obscured by the weakness in the housing-bust states [California, Florida, Arizona,

${ }^{246}$ Civilian Labor Force by Employment Status and Sex, by State: 2011, in StatisticAL AbStract OF the United States 2014, at 404 (2014) [hereinafter Statistical AbStract].

${ }^{247}$ Quoted in Meredith Whitney, Fate of the States: The NeW Geography of American PROSPERITY 155 (2013).

${ }^{248}$ See id. at 157.

${ }^{249}$ Individuals and Families Below Poverty Level-Number and Rate by State: 2001 and 2011, in StATISTICAL ABSTRACT, supra note _, at 486.

${ }^{250}$ Cost of living Index-Selected Urban Areas, Annual Average: 2012, in StatistiCAL ABSTRACT, supra note _, at 502-05.

${ }^{251}$ See Bureau of Economic Analysis, U.S. Dept. of Commerce, Widespread Economic Growth in 2012, June 6, 2013, available at http://www.bea.gov/newsreleases/regional/gdp_state/2013/pdf/gsp0613.pdf. North Dakota's growth was a significant outlier, attributable to its shale oil boom. The second-highest growth was 4.8 percent in Texas - still almost double the national average. See id. Connecticut was the only state with negative growth, but eight states recorded growth under 1 percent for 2012. Ten states had growth over 3 percent. See id. 
Nevada, Illinois, and New Jersey]." 252 The upshot is that "the seventeen states [of] the central corridor grew their economies by 8 percent from 2008 to 2011. The United States as a whole grew its economy by 6 percent. The housing-bust states grew theirs by 2 percent." 253

These short- and medium-term variations pale, however, beside the differential geographical impacts of long-run economic forces. Labor economist Enrico Moretti explains that "the effects of globalization, technological progress, and immigration on American workers are not uniform across the United States. They favor the residents of some cities and hurt the residents of others." ${ }^{254}$ Professor Moretti argues that the U.S. is moving from a manufacturing economy to a knowledge economy, and that "[m]ore than traditional industries, the knowledge economy has an inherent tendency toward geographical agglomeration. ${ }^{, 255}$ Cities and regions that successfully attract innovative firms feed on their own success, while "[c]ommunities that fail to attract skilled workers lose further ground.",256

Other studies of changes in American class and culture have found similar geographical disparities. Richard Florida's famous study of the "creative class"- that is, those working in knowledge-intensive industries - found marked interstate disparities in the proportion of creative class workers. ${ }^{257}$ Likewise, Charles Murray's work on rising inequality within white America found that wealthy and well-educated elites are increasingly clustering into "SuperZips"- that is, zip codes in the $95^{\text {th }}$ through $99^{\text {th }}$ centiles for education and income. ${ }^{258}$ This sort of clustering has profound consequences. As Professor Moretti observes, "[t]he sorting of highly educated Americans into some

\footnotetext{
${ }^{252}$ WHITNEY, supra note 247, at 156; see also id. at 6-7 (lising the "housing-bust" states).

${ }^{253}$ Id. at 156 .

${ }^{254}$ ENRico Moretti, The New GeOGRAPHy OF Jobs 6 (2012).

${ }^{255} I d$. at 5 .

${ }^{256} \mathrm{Id}$.

257 See Richard Florida, The Rise of the Creative Class, Revisited 209-11 (2012).

${ }^{258}$ See Charles Murray, Coming Apart: The State of White America, 1960-2010, at 75-94 (2012).
} 
communities and less educated Americans into others tends to magnify and exacerbate all other socioeconomic differences." 259

To be sure, many of these analyses focus on localities, not states. Murray's SuperZips, for example, cluster around particular metropolitan areas, ${ }^{260}$ and Moretti's knowledge economy is being built around sub-state areas like California's Silicon Valley or North Carolina's Research Triangle. ${ }^{261}$ That suggests, perhaps, that we should focus on the distinctiveness of particular localities - not whole states. ${ }^{262}$ I address that concern in Part V. But the short answer for present purposes is that the presence of a high-tech mecca or a SuperZip cluster affects the economy of the entire state, and these sorts of communities exist in some states but not others.

Finally, to return to Governor Perry's "hunting trip," states have pursued markedly different economic strategies over the years. As one observer described the competition between California and Texas, "[ $\mathrm{t}]$ wo of our biggest and richest states, polar opposites on the political spectrum, are taking radically different approaches to attracting new jobs." 263 Part of the difference is the scope of regulation; Chief Executive magazine, for example, has consistently ranked Texas as the "best state for business"-by which it means the least intrusive regulatory regime-while putting California at the bottom of that poll. ${ }^{264}$ But other aspects of state economic strategy may be important as well.

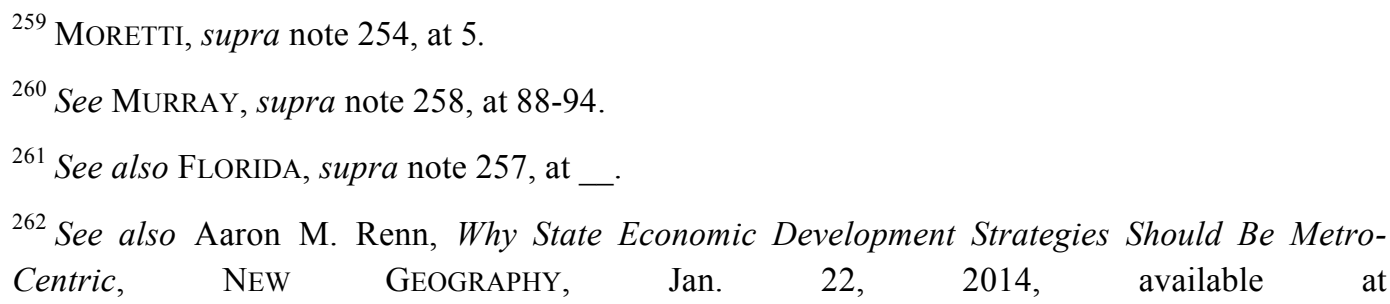
http://www.newgeography.com/content/004144-why-state-economic-development-strategiesshould-be-metro-centric (arguing that "[s]tates are not singular economic units").

${ }^{263}$ California vs. Texas: Wild West Shootout, THE AmERICAN InTEREST, Feb. 6, 2013, available at http://www.the-american-interest.com/blog/2013/02/06/california-vs-texas-wild-west-shootout/.

2642013 Best \& Worst States for Business, ChiEf EXeCuTIVE, May 6, 2013, available at http://chiefexecutive.net/best-worst-states-for-business-2013; see also JP Donlon, Another Triumph for Texas: Best/Worst States for Business 2012, ChiEf EXeCuTIVE, May 2, 2012, available at http://chiefexecutive.net/best-worst-states-for-business-2012 ("Texas easily clinched the No. 1 rank, the eighth successive time it has done so. California earns the dubious honor of being ranked dead last for the eighth consecutive year."). 
Texas took the proceeds of its oil and gas resources and invested them, first in its higher education system and later in sovereign wealth funds designed to lure business to the state. ${ }^{265}$ California has likewise facilitated investment by funding critical infrastructure, but has also relied on progressive social and environmental regulation to appeal to Americans who may find Texas too conservative, flat, or dry.

My point is not to argue for one model over the other. ${ }^{266}$ And I do not deny that the country is more homogeneous in its economic makeup and more interconnected in its economic relationships than, say, in the nineteenth century. Nonetheless, differences in economic conditions and prospects among the states are significant in absolute terms, and they arise at least in part from different approaches to governing. Those approaches are, in turn, linked to different political cultures among the states - a phenomenon I address in the next section.

\section{State Political Culture}

In the late 1940s, John Gunther's famous Inside USA - a very un-Fodors travel guide emphasizing history, politics, and culture - commented that "[n]othing is more remarkable in the United States than the difference between the Dakotas":

These are the two least-known states in the country, and many people think of them casually as a kind of "bloc," which they most certainly are not. North Dakota is probably the most radical state in the union, and South Dakota is one of the most conservative. . . South thinks that North is inhabited exclusively by raging Bolsheviks; North thinks that South is a preserve for all people to the right of Hoover. ${ }^{267}$

Some of these differences have faded by the twenty-first century; North Dakota, like Russia, has largely renounced socialism (which now appears to be confined to

\footnotetext{
${ }^{265}$ See Erica Greider, Big, Hot, Cheap and Right: What America Can Learn from the Strange Genius of Texas _ (2013).

${ }^{266}$ Recent evidence suggests that California may be coming out of its recent funk. See, e.g., Jordan Weissmann, California is Suddenly Adding Jobs Faster than Texas-Why? THE ATLANTIC, Aug. 29, 2012, available at http://www.theatlantic.com/business/archive/2012/08/california-issuddenly-adding-jobs-faster-than-texas-why/261729/ (suggesting that the key difference is that California's economy rests on housing, while Texas rests on oil and gas, so that the fortunes of each state depend simply on which industry is doing better at any given time).
}

${ }^{267}$ GUNTHER, supra note 197, at 237. 
Vermont ${ }^{268}$ and certain inner suburbs of Boston). But looking around the map, one still finds fascinating pairs of states that share many key topographical and demographic characteristics, and yet could not be more different in terms of their politics and style of life. $^{269}$

Contrasts like that between the Dakotas in the last century vividly illustrate the proposition that states have distinctive political cultures. Skeptics of state identity in the legal academy seem to fit well with the broader turn to interdisciplinary studies. But if this body of scholarship were really interdisciplinary, it would take stock of an extensive and longstanding political science literature on state political culture. Gabriel Almond and Sidney Verba's pioneering study defined political culture as a set of "attitudes toward the political system and its various parts, and attitudes toward the role of the self in the system." 270 Daniel Elazar's seminal work defined "political culture" as "the summation of persistent patterns of underlying political attitudes and characteristic responses to political concerns that is manifest in a particular political order." ${ }^{271} \mathrm{He}$ explained that "different political cultures will define fairness in politics differently," for example, and that "political culture will be significant" in "shaping public expectations regarding government services." 272 One can see both of these factors in play in contemporary

\footnotetext{
${ }^{268}$ See, e.g., Jay Parini, The View from Vermont, in THESE UnITED STATEs 2003, supra note 61, at 440 (extolling Vermont's uniquely progressive politics).

${ }^{269} \mathrm{Mr}$. Gunther commented that "Oregon and Washington are twins except as to character," but "nowhere else in the country can the extraordinary tenacity of state characteristics be better observed, the deep-rooted instinct of a state to grow its own way without regard to its neighbor." GunTHER, supra note 197, at 89, 93; see also V.O. KeY, JR., SOUTHERn POLITICS 36 (1950) ("The political distance from Virginia to Alabama must be measured in light years."). Having attended college on the border between New Hampshire and Vermont, the author would testify to similar sharp jurisdictional distinctions arising from fundamentally similar circumstances.

${ }^{270}$ ALMOND \& VERBA, supra note 161, at 13.

${ }^{271}$ ELAZAR, MOSAIC, supra note 63, at 214.

${ }^{272}$ Id. at 214; see also John J. Harrigan \& David C. Nice, Politics AND Policy In STATES AND COMMUNitiEs 10 (10th ed. 2008) (observing that "numerous studies have found that political culture influences the kind of policies adopted by states").
} 
portrayals of Texas and California as the embodiment of distinctive political/economic models. $^{273}$

Studies emphasizing political culture have been somewhat controversial in political science. Part of the problem is the inherent fuzziness of concepts like "culture" or "national character." As one leading analysis pointed out, "[p]olitical culture is one of the most popular and seductive concepts in political science; it is also one of the most controversial and confused." ${ }^{274}$ Hence, cultural analysis tended to lose ground to seemingly "sharper" approaches; as Ronald Inglehart lamented, "[s]ince the late 1960s, rational choice models based on economic variables have become the dominant mode of analysis; while cultural factors have been deemphasized to an unrealistic degree. ${ }^{275}$ More recent work on political culture has addressed this failing by taking a more empirical turn. ${ }^{276}$ Other critics have rejected the notion "that cultural factors have any systematic effects on political and economic outcomes."277 Even critics acknowledge, however, that "political culture is likely to help explain certain characteristics of political institutions" and remains "a useful explanatory tool." 278 My purposes—which are simply

${ }^{273}$ See California v. Texas: America's future, The ECONOMIST, July 9, 2009, available at www.economist.com/node/13990207 (comparing California's model, featuring high taxes and extensive government regulations and services, with Texas's "small government" model).

${ }^{274}$ David J. Elkins \& Richard E.B. Simeon, A Cause in Search of Its Effect, or What Does Political Culture Explain? 11 Comparative Politics 127, 127 (1979); see also Jeffrey Olick \& Tatiana Omeltchenko, Political Culture, in InTERnational EnCyClopedia of the Social SCIENCES 300-02 (2008) (concise summary of the development of the literature on political culture).

${ }^{275}$ Ronald Ingleheart, The Renaissance of Political Culture, 82 AM. POL. SCI. REV. 1203, 1203 (1988).

${ }^{276}$ See id. at 1225-28; see also David Young Miller, The Impact of Political Culture on Patterns of State and Local Government Expenditures, 21 PuBLIUs 83 (1991) (finding empirical support for Elazar's classificatios in expenditure patterns); Charles A. Johnson, Political Culture in American States: Elazar's Formulation Examined, 20 AM. J. POL. SCI. 491 (1976) (finding empirical support for Elazar's categories); Ira Sharkansky, The Utility of Elazar's Political Culture: A Research Note, 2 POLITY 66 (1969) (same).

${ }^{277}$ Robert W. Jackman \& Ross A. Miller, A Renaissance of Political Culture? 40 Am. J. Pol. Sci. 632, 653 (1996); see also Elkins \& Simeon, supra note 274, at _.

${ }^{278}$ See Elkins \& Simeon, supra note 274, at 141, 143; see also id. at 142 ("Culture is unlikely to be of much help in explaining why alternative A was chosen over alternative B-but it may be of 
to identify factors that may make particular states different from one another, rather than to explain particular policy choices - steer clear of the main points in controversy.

Much of the political culture literature focuses on the national level. Writing in 1968, however, Samuel Patterson observed that "the states can be treated for analytical purposes as relatively independent political systems with political cultures at least somewhat distinctive to themselves." ${ }^{279}$ Professor Elazar saw the political cultures of the state as functions of the sedimentary deposits left by migrations of three great political subcultures-"moralistic," "individualistic," and "traditionalistic"-over the course of many generations. ${ }^{280} \mathrm{He}$ explained that "representatives of each [subculture] are found within every state to varying degrees. In fact, unique aggregations of cultural patterns are clearly discernible in every state. These cultural patterns give each state its particular character and help determine the tone of its fundamental relationship, as a state, to the nation.,281

Professor Elazar was not an empiricist, and efforts to test his theory empirically have generated varying results. ${ }^{282}$ The main empirical difficulty seems to be identifying the "missing link" between political culture and public policy; even empirical critics concede, however, that Elazar's "tripartite classification of political cultures has emerged as one of the leading predictors of the interstate variance in public policy outputs. ${ }^{283}$ For example, a more recent empirical analysis of state budgets yielded results "consistent with the continued existence of distinct cultures among the states. Despite the age of Elazar's cultural system and ongoing demographic changes, the culture-expenditure link

great help in understanding why A and B were considered, while no thought was given to C, D, or E.").

${ }^{279}$ Patterson, supra note 73, at 195.

${ }^{280}$ ELAZAR, MOSAIC, supra note 63, at 229-57.

${ }^{281}$ ElazAr, AmERICAN Federalism, supra note 196, at 134. See id. at 135, figure 5.4, for a map.

${ }^{282}$ Compare, e.g., Charles A. Johnson, Political Culture in American States: Elazar's Formulation Examined, 20 AM. J. POL. SCI. 491, (1976) (finding empirical support for Elazar's theory and concluding that "political culture is related to political characteristics and political decisions of American states"), with [critics].

${ }^{283}$ David Lowery \& Lee Sigelman, Political Culture and State Public Policy: The Missing Link, 35 WeStern POL. QUARTERLy 376, 376, 383 (1982). 
remains intact." ${ }^{284}$ And Robert Putnam's study of interstate differences in social capital yielded a pattern "astonishingly similar" to Elazar's analysis. ${ }^{285}$

In any event, my concern is not with whether Professor Elazar correctly classified the cultures of the American states, but simply with whether political culture exists as a meaningful phenomenon and varies among the States. ${ }^{286}$ None of the empirical work testing Elazar's theory denies that this is the case, and his conception of state political culture remains a mainstay of the literature on state governance. ${ }^{287}$ Another way to uncover the importance of state political culture would be to evaluate the importance of an individual's state of residence in predicting political opinions. An important study of "Statehouse Democracy" conducted by Robert Erikson, Gerald Wright, and John McIver aggregated CBS News/New York Times surveys from 1976 to 1998 that asked questions on ideological and partisan identification and broke the data down by the respondents" state of residence. They found that " $[t]$ o some degree, state differences in political preferences follow simply from the states' group compositions. Each electorate is a unique composite of political groupings, and these help to determine the state's political views." 288

That evidence helps to show that states are meaningfully distinctive- that is, that differences in demographic characteristics do cash out into important political differences. But it would doesn't tell us much about identity or the existence of a

\footnotetext{
${ }^{284}$ Steven G. Koven \& Christopher Mausoff, The Influence of Political Culture on State Budgets: Another Look at Elazar's Formulation, 32 AM. REV. OF Public AdmIN. 66, 74 (2002); see also id. at 66 (citing several earlier studies of "[t]he culture-public expenditure relationship" that "found significant correlations using a range of methods, including multiple regression and discriminant analysis"); Lawrence M. Mead, State Political Culture and Welfare Reform, 32 POLICY STUD. J. 271, 286 (2004) (concluding, based on an empirical analysis of state welfare reform efforts, that "[c]ulture clearly matters for the performance of American states").

${ }^{285}$ PUTNAM, supra note 237, at 294.

${ }^{286}$ For arguments that different schema better capture the divergent political cultures of the states, see, e.g., Joel Lieske, American State Cultures: Testing a New Measure and Theory, 42 PubluUs 108 (2011).

${ }^{287}$ See, e.g., HARRIGAN \& NICE, supra note 272, at 9-11 (state and local government textbook using Elazar to introduce basic determinants of governance).

${ }^{288}$ Robert S. Erikson, Gerald C. Wright, \& John P. MCIVer, Statehouse Democracy: Public OPinion AND Policy IN THE AMERICAN STATES 47 (1993)..
} 
cohesive state political culture. The Statehouse Democracy study further found, however, that "collective sentiment can be more than the sum of views of the represented groups. A second potential source of state attitudes is state residence itself." 289 Even controlling for demographic characteristics, Professors Erikson, Wright, and McIver found that "indigenous 'state' effects, which we attribute to state-to-state differences in political culture, account for far more of the interstate variance of partisanship and ideology than does interstate variation in the demographic compositions of state populations. A state's partisan or ideological bent seems more a function of its political history and development than of the characteristics of its population. ${ }^{290}$ The authors concluded that "[s]tates are active and meaningful political communities whose electorates have distinctive preferences; the states are not just collections of atomistic individuals whose opinions automatically flow from their personal socio-economic characteristic."291

Political science is not the only discipline to identify different cultural dispositions among the states. Historian C. Vann Woodward, for example, attributed the distinctive political culture of the Southern states to the experience of rebellion and defeat in the Civil War; he argued, during the Vietnam period, that as the only portion of the country that had ever lost a war, the South had unique wisdom to offer a nation that arguably had an over-optimistic view of its own invincibility. ${ }^{292}$ Likewise, Texas historian Gregg Cantrell tells how Texas's political culture shifted during the Progressive era from the Southern regional narrative of the "Lost Cause" to a more Texas-specific (and less depressing) story emphasizing the Texas War of Independence and the

${ }^{289}$ Id.

${ }^{290} I d$. at 71 .

${ }^{291} I d$. at 10. The same authors updated their research in 2006 but found no reason to question their earlier conclusions concerning the importance of state residence as an explanatory factor with respect to political attitudes. See Robert S. Erikson, Gerald C. Wright, \& John P. McIver, Public Opinion in the States: A Quarter Century of Change and Stability, in JEFFREY E. COHEN, ED., Public Opinion In State Politics 229 (2006); see also Barbara Norrander \& Clyde Wilcox, State Residency, State Laws, and Public Opinion, in CoHEN, supra, at 38, 49 (finding that "[s]tate residency adds 10 to 25 percent to the explained variation in individual-level opinion, while demographic factors contribute approximately half of the explained variation").

${ }^{292}$ WOODWARD, supra note 186 , at 25. 
Alamo. ${ }^{293}$ Historians focused on other parts of the country could doubtless tell similar stories.

More broadly, David Hackett Fischer, like Professor Elazar in political science, has traced much of the development of American political culture to four distinct migrations from different regions of Britain to particular locations in North America. He concludes that "[e]ven as the ethnic composition of these various regions of the United States has changed profoundly, regional cultures themselves have persisted, and are still very powerful even in our own time. All of them derive from folkways that were planted in the American colonies more than two centuries ago." 294

Other disciplines likewise find systematic differences among states and regions relevant to political culture. A recent study by social psychologists found "strong evidence that there are robust psychological differences between regions of the United States that are associated with important geographical factors." ${ }^{295}$ A different study ranked the states in terms of "tightness (many strongly enforced rules and little tolerance for deviance) versus looseness (few strongly enforced rules and greater tolerance fo deviance)," finding that these characteristics were "systematically associated with statelevel outcomes," including substance abuse, homelessness, gender equality, innovation, and happiness. ${ }^{296}$

${ }^{293}$ See Gregg Cantrell, The Bones of Stephen F. Austin: History and Memory in Progressive-Era Texas, in Gregg Cantrell \& Elizabeth hayes Turner, eds., Lone Star Pasts: Memory AND History IN TEXAS 39, 41 (2007).

${ }^{294}$ See FisCher, supra note 63, at 10-11; see also COLIN WOODARD, AMERICAN NATIONS: A History of the Eleven Rival Regional Cultures of North America (2011) (making a similar argument).

${ }^{295}$ Peter J. Rentfrow, Samuel D. Gosling, Markus Jokela, David J. Stillwell, \& Michal Kosinski, Divided We Stand: Three Psychological Regions of the United States and Their Political, Economic, Social, and Health Correlates, 105 J. Personality \& SOC. PSYCH. 996, 1006 (2013).

${ }^{296}$ Jesse R. Harrington \& Michele J. Gelfand, Tightness-Looseness Across the 50 United States, 111 Proc. NAT'L ACAD. SCI. 7990, 7995 (2014); see also Jesse Harrington \& Michele Gelfand, Tightness and Looseness: A New Way to Understand Differences across the 50 United States, SCIENTIFIC AMERICAN, July 2, 2014, available at http://www.scientificamerican.com/article/tightness-and-looseness-a-new-way-to-understanddifferences-across-the-50-united-states/. 
People who take the trouble to look will find that "the fifty states . . . somehow stubbornly resist blending into a single undifferentiated whole." 297 Political scientists, historians, geographers, economists, and sociologists are all well-attuned to these differences. In this respect, the One Nation argument is testament to the continuing insularity of legal scholarship. The legal literature's insularity on this point becomes all the more puzzling, moreover, when one surveys the extent to which state-by-state diversity is reflected in the law itself.

\section{B. How Different are the States? Policy Outputs}

In 2010, Arizona enacted what both proponents and critics considered to be "the broadest and strictest immigration measure in generations," criminalizing the failure to carry immigration documents and conferring broad power on state and local police to detain persons suspected of being in the country illegally. ${ }^{298}$ Arizona's law bore a strong kinship to California's Proposition 187, enacted sixteen years earlier, which denied public services, including healthcare and education, to undocumented immigrants. ${ }^{299}$ In sharp contrast, "Arizona-style legislative initiatives unfriendly to immigrants have often hit brick walls in Texas. ${ }^{, 300}$ While governor of the Lone Star State, George W. Bush vocally opposed Proposition 187, and his successor Rick Perry not only thwarted

${ }^{297}$ Matt Weiland, Preface, in STATE BY STATE, supra note 3, at xiv.

${ }^{298}$ Randal C. Archibold, Arizona Enacts Stringent Law on Immigration, N.Y. TimES, April 23, 2010, available at http://www.nytimes.com/2010/04/24/us/politics/24immig.html. Three years earlier, Arizona had also ramped up state enforcement of laws prohibiting employers within the state from hiring undocumented immigrants. Unlike the 2010 law, the employer provisions were largely upheld by the U.S. Supreme Court. Compare Arizona v. United States, 132 S. Ct. 2492 (2012) (holding most provisions of the 2010 act preempted by the federal immigration laws), with Chamber of Commerce v. Whiting, 131 S. Ct. 1968 (2011) (upholding the "Legal Arizona Workers Act" against preemption challenge).

${ }^{299}$ See Mark Z. Barabak, The Politics of California's Proposition 187 in One Chart, L.A. TIMES, June 18, 2014, available at http://www.latimes.com/nation/politics/politicsnow/la-pn-politics-ofproposition-187-in-one-chart-20140617-story.html. The politics of immigration in California have since changed considerably, in part due to the election of Hispanic legislators in significant numbers. See id.

${ }^{300}$ Katie Glueck, Texas GOP Touts Its Hispanic Model, PoliticO, Nov. 30, 2012, available at http://www.politico.com/story/2012/11/texas-gop-touts-its-hispanic-model-84465.html. 
proposals to emulate Arizona but oversaw enactment of a state DREAM Act permitting foreign-born children of undocumented immigrants to pay in-state tuition at the state's public universities. ${ }^{301}$ Texas's divergent approach is grounded in its historical ties, cultural affinity, and strong economic links to Mexico, as well as the political realities of a state with a forty-percent Hispanic population. ${ }^{302}$

The divide between Arizona and California, on the one hand, and Texas, on the other, over immigration policy is just one among many examples of states with common problems making divergent policy choices about how to address them. One might well assume, for example, that the two inland states of northern New England, sharing such similar topography and demography, would produce fundamentally similar legal regimes. And yet New Hampshire is rated one of the most business-friendly regulatory climates in the nation, ${ }^{303}$ and it lacks both sales and income taxes. Vermont, on the other hand, has

301 See John D. Graham, Bush on the Home Front: Domestic Policy Triumphs and SeTBACKS 227-28 (2010); Mallie Jane Kim, Rick Perry Stands by Texas DREAM Act, U.S. NEWS \& WORLD REPT., July 25, 2011, available at http:/www.usnews.com/news/articles/2011/07/25/rick-perry-stands-by-texas-dream-act; Texas Gov: Arizona Immigration Law 'Not Right' for Texas, Fox News, Apr. 29, 2010, available at http://www.foxnews.com/politics/2010/04/29/texas-governor-arizona-immigration-law-righttexas/.

302 See Wayne Thorburn, Red State: An Insider's Story of How the GOP Came to Dominate Texas Politics 218-29 (2014); Jessie Katz, Prop. 187 Gives Texas a Selling Point in Mexico, L.A. TIMES, Feb. 6, 1995, available at http://articles.latimes.com/1995-02-06/news/mn28768 1_mexico-city. Texas policy has not, of course, been unremittingly pro-immigration; Governor Perry, for example, has famously promoted a border fence as well as unilateral measures to restrict the entry of illegal immigrants. See, e.g., Sarah Mervosh, Perry blasts Obama over border, terrorism threat, DALlasNews, Aug. 29, 2014, available at http://www.dallasnews.com/news/politics/state-politics/20140829-perry-blasts-obama-overborder-terrorism-threat.ece. Concerns about border security (and frustrations with the federal government's failure to provide it) have been a virtually constant aspect of Texas history. See FEHRENBACH, supra note 414, at 275-76.

${ }^{303}$ See Dean Stansel, José Torra, \& Fred McMahon, Economic Freedom of North America 2014, at 7, available at http:/www.freetheworld.com/2014/efna/economic-freedom-of-north-america2014-us-edition.pdf (rating New Hampshire fifth in "economic freedom"). 
high taxes, strict regulations, and recently tried to erect a single-payer public healthcare system. $^{304}$

This section focuses on the different legal choices states have made. I have not tried to survey all the differences in state laws around the country. Even if that were practicable, the end result would surely have the same glass-half-empty/glass-half-full quality we saw in the last section. The existence of distinctive state political cultures has not prevented the rise of a national political culture as well, and all the states share a common legal heritage. ${ }^{305} \mathrm{~A}$ modern economy and a sense that states face many similar problems both create incentives for harmonization, and organizations like the American Law Institute and the Commission on Uniform State Law have made important progress in making states' laws more uniform on particular questions. All I seek to show is that this shared national legal tradition has not caused our fifty state legal regimes to collapse into one homogeneous mass. Major differences remain, and these differences occur on questions that matter a great deal to Americans.

I begin with state constitutions. The debate over state constitutionalism-and, in particular, over whether courts should interpret state constitutions in light of the particular culture and traditions of the state-is the one place in the legal literature where scholars have debated the existence and significance of state identity in some depth. I then turn to a brief survey of state policy divergence on a range of issues, including crime and punishment, taxing and spending, family law, and environmental policy. Significantly, I find that significant policy diversity persists even in areas, like environmental law, where the state role is ostensibly limited to implementing federal regulatory schemes. Finally, I also consider the significance of recent debates about the "red state/blue state" divide in American politics.

These divergent state policy outputs matter to my argument in three ways. First, they contribute to making each state feel more distinctive. Through a distinct mix of fiscal and regulatory choices, for example, Texas and California have created starkly different economic models whose effects pervade everyday life. Second, these distinctive

\footnotetext{
${ }^{304}$ See id. (ranking Vermont forty-eighth in "economic freedom"); Sarah Wheaton, Why Single Payer Died in Vermont, Politico, Dec. 20, 2014, available at http://www.politico.com/story/2014/12/single-payer-vermont-113711.html.

${ }^{305}$ See, e.g., Ford W. Hall, The Common Law: An Account of Its Reception in the United States, 4 VAND. L. REV. 791 (1951).
} 
choices are directly relevant to several of the values - experimentation, accommodation to regionally diverse preferences, providing opportunities to participate in politics - that federalism is supposed to serve. Third - most important to my argument - the making of these choices through a state's deliberative processes is itself a constitutive act that builds a sense of community and loyalty among a state's citizens. As the political theorist Anna Stilz has observed, "over time political cooperation can constitute a group of citizens into a collective with important ties binding them together. ${ }^{306}$

\section{State Constitutions}

In 1977, Justice William Brennan published an essay in the Harvard Law Review urging state courts to interpret their own state constitutions broadly to protect individual rights. ${ }^{307}$ Noting the Burger Court's tendency to cut back on the Warren Court's broad interpretations of those rights, Brennan issued "a clear call to state courts to step into the breach. . . . With federal scrutiny diminished, state courts must respond by increasing their own." 308 Brennan's essay helped spark a "new judicial federalism" that featured both increased interest in state constitutional options by jurists and a vigorous academic debate about the legitimacy and efficacy of state constitutionalism as a substitute for broad interpretations of federal rights. ${ }^{309}$

The importance of state constitutions transcends Justice Brennan's "new judicial federalism," however. State constitutions play a role in constituting each state as an independent political community, and we may expect a state's constitution to reflect that community's most fundamental values and commitments. ${ }^{310}$ The extent of variation

\footnotetext{
${ }^{306}$ Anna Stilz, Why Does the State Matter Morally? Political Obligation and Particularity, in VARieties of Sovereignty AND CitizenshiP 244, 260 (Sigel R. Ben-Porath \& Rogers Smith, eds. 2012).

${ }^{307}$ William J. Brennan, Jr., State Constitutions and the Protection of Individual Rights, 90 HARV. L. REV. 489 (1977).

${ }^{308} I d$. at 503.

${ }^{309}$ See, e.g., Symposium: The Emergence of State Constitutional Law, 63 TEX. L. REV. 959 (1985); Earl M. Maltz, False Prophet-Justice Brennan and the Theory of State Constitutional Law, 15 Hastings Const. L. Q. 429 (1988); Hans Linde, First Things First: Rediscovering the States' Bills of Rights, 9 U. BALT. L. REV. 379 (1980).

${ }^{310}$ See, e.g., James T. McHugh, Ex Uno Plura: State Constitutions and Their Political Cultures 2 (2003); G. Alan TARr, Understanding State Constitutions 3 (1998).
} 
among state constitutions may thus tell us something important about the distinctiveness of states in our federal system. Conversely, many critics of the new judicial federalism have found the results of Justice Brennan's call underwhelming. ${ }^{311}$ That conclusion, as I noted earlier, ${ }^{312}$ has been interpreted to demonstrate that the states lack distinctive identities.

The most vigorous critic, James Gardner, reviewed a sampling of 1208 opinions issued in 1990 by the high courts in seven states. ${ }^{313} \mathrm{He}$ found that the state courts in question decided state constitutional cases in only about 21 percent of their cases; that they resorted to state constitutional grounds only grudgingly and often failed to specify the basis of their rulings; that they frequently construed their state constitutions in "lockstep" with analogous federal provisions; and that they almost never analyzed the particular history of state constitutional provisions. ${ }^{314}$ Not one to mince words, Professor Gardner concluded that "state constitutional law today is a vast wasteland of confusing, conflicting, and essentially unintelligible pronouncements." 315

${ }^{316}$ Justice Brennan's call focused on state rights provisions - the area in which state constitutions most resemble the federal Constitution, and hence that in which the gravitational force of the federal provisions and U.S. Supreme Court decisions

${ }^{311}$ See, e.g., GARDNER, supra note 15 , at 45-47.

${ }^{312}$ See supra notes ___ a and accompanying text.

${ }^{313}$ See Gardner, Failed Discourse, supra note 43, at 778-80.

${ }^{314}$ See id. at $780-94$.

${ }^{315}$ Id. at 763 . Professor Gardner did not argue that state constitutions should be interpreted in line with parallel federal provisions; rather, he argued for using state constitutions as a way to vindicate the broader view of federal rights articulated by dissenting justices like Justice Brennan. See GARDNER, supra note 15, at 121-23. Gardner's view thus ends up being a state constitutional law version of Jessica Bulman-Pozen's Partisan Federalism or Heather Gerken's Dissenting by Deciding. See supra notes _ and accompanying text.

${ }^{316}$ Professor Gardner's work has spawned a mini-literature of essays by lawyers in particular states insisting that, whatever may be going on in other states, their state has a unique constitutional tradition. See, e.g., Ronald L. Nelson, Welcome to the "Last Frontier," Professor Gardner: Alaska's Independent Approach to State Constitutional Interpretation, 12 ALASKA L. REV. 1 (1995); David Schuman, A Failed Critique of State Constitutionalism, 91 MicH. L. REV. 274 (1992) (Oregon). 
interpreting them has the strongest pull limiting state-by-state diversity. Justice Brennan's goal, moreover, was overtly political: He hoped to push the interpretation of individual rights in a more liberal direction that seemed blocked, at the time, in the federal courts. ${ }^{317}$ It was probably unrealistic to expect largely elected state judiciaries to go further in protecting criminal defendants than life-tenured federal judges were willing to go. In any event, my survey here focuses on the respects in which state constitutions diverge from the national model, because in the absence of a federal focal point, different state constitutions may be more likely to branch out in different directions.

Many of the most striking state constitutional divergences from the model occur on the structural side. ${ }^{318}$ The most obvious differences involve the structure of the state constitutions themselves. As Alan Tarr notes, "probably their most striking feature is their length." 319 The longest (Alabama's) is approximately 376,000 words, while the shortest (Vermont's) is still roughly 8500 words; the mean is over 31,000 words. ${ }^{320}$ By comparison, the U.S. Constitution clocks in at around 4,400 words. Much of the extra length is taken up with “'constitutional legislation,' provisions that in their length and detail are indistinguishable from statutes. ${ }^{, 321}$ State constitutions are also amended-and even replaced - far more frequently than the federal one. ${ }^{322}$ Louisiana has gone through eleven constitutions in just over two centuries, New York has had four, and the mean for

\footnotetext{
317 See, e.g., Paul W. Kahn, Two Communities: Professional and Political, 24 RUTGERS L. J. 957, 968 (1993); Maltz, supra note 309, at 432. As Professor Maltz has pointed out, Justice Brennan was not generally a champion of federalism in the rest of his jurisprudence. See id. at 430-32.

${ }^{318}$ Jim Gardner's most recent salvo focuses on government structure and asserts that, although our system affords state wide opportunities to experiment with structural opportunities, "states have not availed themselves of these opportunities." James A. Gardner, Autonomy and Isomorphism: The Unfulfilled Promise of Structural Autonomy in American State Constitutions, 59 WAYNE L. REV. 31, 34 (20140) [hereinafter Gardner, Isomorphism]. Professor Gardner's article focuses rather narrowly on voter apportionment following the Supreme Court's one man-one vote decisions. Even if the states are similar on that point, it is a leap-to say the least-to say that the states are simply unwilling or unable to innovate on structural matters. See id. at 66 .

${ }^{319}$ TARR, supra note 310 , at 9.

${ }^{320}$ See State Constitutions, in THE BoOK of THE STATES _ (Audrey Wall ed. 2014).

${ }^{321}$ TARR, supra note 310 , at 9.

${ }^{322}$ See id. at 23-27.
} 
all states is just under three. ${ }^{323}$ The states have adopted over 5900 amendments to their current set of constitutions (almost 120 per state. ${ }^{324}$ Unlike the national government, states have been unafraid to hold state constitutional conventions and have done so over 230 times. $^{325}$

The frequency of state constitutional amendment and replacement, as well as the highly-specific and frequently mundane character of many state constitutional provisions, has prompted critics to argue that state constitutional discourse simply lacks the gravitas to define a meaningful political community. ${ }^{326}$ A favorite target is New York's constitutional provision regulating the width of ski trails. ${ }^{327}$ But as Emily Zackin points out, that provision has a far more interesting history. It actually amends a more foundational provision mandating that the state's forest preserve be "forever kept as wild forest land." ${ }^{, 328}$ Construction of ski trails would require timber removal; hence, the ski trail amendment carved out a limited exception to the "Forever Wild" principle. Professor Zackin concludes that "[m]any, if not all, of the details in state constitutions

\footnotetext{
${ }^{323}$ See State Constitutions, in THE Book of THE STATES _ (Audrey Wall ed. 2014).
}

${ }^{324}$ TARR, supra note 310 , at 24 . Alabama is the amendment champion, with over 580 amendments, but that number is arguably distorted by the inclusion of numerous local amendments that only apply to particular counties. See State Constitutions, in THE BOOK OF THE STATES_n. (a) (Audrey Wall ed. 2014).

${ }^{325}$ TARR, supra note 310 , at 25.

${ }^{326}$ See Gardner, Failed Discourse, supra note 43, at 818-820 (concluding that state constitutions reflect communities that are "frivolous, or fickle, or unreflective" and therefore "not worthy of respect"). As Emily Zackin points out, however, "state constitutions are so detailed in large part because these documents provide so many points of entry for the direct participation of citizens and citizen groups." EMILY Zackin, LoOKING fOR Rights in All the Wrong Places: Why State Constitutions Contain America's Positive Rights 23 (2013). These sorts of opportunities to participate in government are one of the quintessential virtues of federalism, see, e.g., Merritt, supra note 149 , at $7-8$, as well as one of the ways that a political community constitutes itself over time, see Stilz, supra note 306, at 260.

${ }^{327}$ See N.Y. ConST. art. 14, § 1; Gardner, Failed Discourse, supra note 43, at 819-20 (mocking this provision).

${ }^{328}$ N.Y. CONST. art. $14, \S 1$ 
simultaneously describe highly specific policies and reflect the important principles of governance that these policies were created to advance." 329

The specific provisions of state constitutions deviate from the federal model with respect to each branch of government. State legislatures, for example, possess plenarynot enumerated - powers. ${ }^{330}$ This means that they have residual powers vis-à-vis the other branches of state governments, and that limitations on state legislative powers are "the fundamental interpretive issue under state constitutions." 331 Because they address a fundamentally different structural problem from the federal notion of enumeration, these limits tend not to have counterparts; there is no federal model for states to coalesce around. Not surprisingly, the results vary considerably. State constitutions adopted in the nineteenth century tend to include a wide variety of procedural checks on legislative action, such as supermajority or multiple bill-reading requirements and limits on the length and frequency of legislative sessions, as well as substantive prohibitions, such as bars to loaning the credit of the state to private entities or granting divorces. ${ }^{332}$ State constitutions enacted after the Depression, by contrast, were more concerned with "structuring state government to act vigorously" to confront public problems; they thus contained significantly fewer procedural or substantive limits on legislative power. ${ }^{333}$

State constitutions have almost uniformly rejected any notion of a "unitary" executive - a principle often thought to lie at the heart of the national separation of powers. ${ }^{334}$ Only New Jersey follows the federal model. ${ }^{335}$ This means that state constitutions must define the respective purviews of separately elected governors,

\footnotetext{
${ }^{329}$ ZACKIN, supra note 326 , at 28.

${ }^{330}$ See TARR, supra note 310 , at 16 . The North Carolina Constitution, for example, provides simply that "[t]he legislative power of the State shall be vested in the General Assembly," without any further enumeration. N.C. CONST. Art. II, $\S 1$.

${ }^{331}$ See TARR, supra note 310, at 16.

${ }^{332}$ See id. at $118-21$.

${ }^{333}$ Id. at $155-57$.

${ }^{334}$ Compare TARR, supra note 310, at 17 ("[M]ost state executive articles establish a nonunified executive."), with Morrison v. Olson, 487 U.S. 654, 705 (1988) (Scalia, J., dissenting) (insisting that Article II's provision vesting "[t]he executive Power" in the President "does not mean some of the executive power, but all of the executive power").

${ }^{335}$ See TARR, supra note 310, at 17.
} 
attorneys general, secretaries of state, and the like-a problem that simply does not exist in federal law. As one might expect, state executive officers vary significantly in their mandate and power. The Texas Railroad Commissioner, a separately-elected office that doesn't exist in most states, runs "one of the most important regulatory bodies in the nation" because it "strongly influence[s] the supply and price of oil and natural gas throughout the United States." 336 In Tennessee, the Attorney General is not only unelected, but appointed by the state supreme court. ${ }^{337}$ Some state constitutions avoid one of the most difficult and contentious questions of federal separation of powers law by explicitly authorizing and empowering particular administrative agencies, such as Florida's Game and Fresh Water Fish Commission. ${ }^{338}$

State courts likewise differ profoundly from their federal counterparts - and from one another. Start with judicial selection, which ranges from partisan elections ( 7 states) to nonpartisan elections (15 states) to pure gubernatorial appointments (5 states) to appointments from a list produced by a nominating commission (21 states) to legislative appointment ( 2 states). ${ }^{339}$ More fundamentally, states differ in their conception of the "judicial power." Some have a broader conception of standing or a narrower conception of mootness than the federal courts. ${ }^{340}$ Others authorize advisory opinions by express constitutional provision ( 8 states) or by statute ( 3 states), while ten others have rejected or

\footnotetext{
${ }^{336}$ David F. Prindle, Railroad Commission, HandBook of TeXas OnLINe, June 15, 2010, available at http://www.tshaonline.org/handbook/online/articles/mdr01.

${ }^{337}$ See Eric Schelzig, 8 Apply to Become Tennessee Attorney General, THE TENNESSEAN, Aug. 29, 2014, available at http://www.tennessean.com/story/news/politics/2014/08/29/apply-becometennessee-attorney-general/14821347/.

${ }^{338}$ See TARR, supra note 310 , at 17-18.

339 See the cool interactive map at Judicial Selection in the States, JUDGEPEDIA, http://judgepedia.org/Judicial selection in the states (visited Feb. 17, 2015).

${ }^{340}$ See, e.g., Tileston v. Ullman, 318 U.S. 44 (1943) (per curiam) (dismissing a doctor's challenge to a Connecticut restriction on contraceptives on the ground that the doctor could not assert the constitutional rights of his patients; the Connecticut Supreme Court had decided the case on the merits pursuant to a broader conception of standing under the state constitution); DeFunis v. Odegaard, 416 U.S. 312 (1974) (dismissing an appeal on mootness grounds that the Washington Supreme Court had been willing to hear based on an exception for matters of continuing public concern).
} 
abandoned this practice. ${ }^{341}$ And all states diverge sharply from the federal judiciary by recognizing a common lawmaking power long denied to the federal courts (at least outside the maritime jurisdiction). ${ }^{342}$ Although all states enjoy this power, they differ in the extent to which legislatures intrude through codification, in their willingness to go along with unification efforts like the Uniform Commercial Code, and even (in the case of Louisiana) to the extent they consider themselves common law jurisdictions at all.

Finally, there are the various individual rights afforded by state constitutions against government action. As I have noted, the state constitutionalism debate has focused on the extent to which state courts do (or should) interpret those rights more broadly than their counterparts in the federal Bill of Rights. That debate tends to ignore, however, state constitutional rights without federal cognates-in particular, state constitutional provisions for positive rights to government protection from social or economic harms. Although the national Constitution generally lacks such rights, ${ }^{343}$ Emily Zackin has demonstrated that social movements throughout our history have managed to enshrine positive rights to public education, workers' rights, and rights to a healthy environment in state constitutions. ${ }^{344}$ "To American reformers seeking rights to a more protective government," Professor Zackin writes, "state constitutions have often appeared to be the most accessible and relevant constitutions." 345 This historical experience

\footnotetext{
${ }^{341}$ See Richard H. Fallon, Jr., John F. Manning, Daniel J. Meltzer, \& David L. Shapiro, Hart AND WeChSLER's The Federal COURTS AND the Federal System 57-58 (6th ed. 2009) [hereinafter HART \& WECHSLER].

${ }^{342}$ See Burt Neuborne, State Constitutions and the Evolution of Positive Rights, 20 RutGERs L.J. 881, 896-97 (1989) ("Unlike their federal counterparts, state courts continue to play an avowedly generative role in the growth of American law. As the energy of state courts in forging new common law rules in areas as diverse as products liability and corporate take-overs attests, state courts are im-bued with the power and creative ethos of the common law tradition."); Ernest A. Young, A General Defense of Erie Railroad Co. v. Tompkins, 10 J. L. ECON. \& POL'Y 17, 101-04 (2013) (exploring the sources of state courts' lawmaking powers).

${ }^{343}$ See, e.g., Cass R. Sunstein, Why Does the American Constitution Lack Social and Economic Guarantees? 56 SYRACUSE L. REV. 4 (2005).

${ }^{344}$ See ZACKIN, supra note 326, at 2-3. One reason that the current debate neglects these rights is that it focuses on courts, while many of the positive rights were directed primarily toward forcing legislative action and not toward judicial enforcement. See id. at 109 (discussing workers' rights).

${ }^{345}$ ZACKIN, supra note 326, at 212.
} 
strongly suggests not only that state constitutions importantly differ from both the federal charter and one another, but that citizens have found state constitutional activism to be an important form of civic participation.

\section{State Policy Divergence: A Sampler}

If states really are distinctive political communities, then we would expect them to make different choices on any number of significant policy issues. A comprehensive test of that hypothesis, of course, would require a survey of nearly all the law. I have instead picked a few significant and fairly representative areas of state policy and noted some important state-by-state variations within each. One could proliferate other examples, but these should be sufficient to get a sense of the significant diversity from state to state.

Fiscal Policy: Fiscal policy is worth looking at both because it is one of the most contentious areas of contemporary politics and because it determines the "scope and scale" of state government. ${ }^{346}$ A recent survey reveals "a great deal of variation across the states in fiscal scale . . . Even after excluding Alaska, own-source general revenue and general spending per capita are more than twice as high for the state ranked second (Wyoming in both cases) as for the states ranked fiftieth (Georgia and Florida, respectively). ${ }^{347}$ The factors that seem to drive fiscal scale are about what one would expect: "differences in the abilities of state residents to pay for public services, preferences for government programs, transfers of revenues from the federal government, and institutions that govern how decisions are made." 348

States vary significantly in the ways they have chosen to generate revenue, and these variations are particularly salient to citizens. One need only check the license plates in the parking lots at New Hampshire shopping centers near the state's borders to see the effect of the Granite State's decision to eschew a sales tax. And Governor Rick Perry's sales pitch to California businesses surely emphasized that their employees could avoid paying state income tax by relocating to Texas. Top individual income tax rates vary from 12.3 and 11 percent in California and Hawaii, respectively, to 4.54 and 3.22 percent

\footnotetext{
${ }^{346}$ Robert G. Lowry, Fiscal Policy in the American States, in Politics In the AMERICAN STATES: A Comparative Analysis 309, 310 (Virginia Gray, Russell L. Hanson, \& Thad Kousser eds. 10th ed. 2013)

${ }^{347}$ Id. at 311 .

${ }^{348} I d$. at 313 .
} 
in Arizona and North Dakota. ${ }^{349}$ Eight states (Alaska, Florida, Nevada, New Hampshire, South Dakota, Texas, Washington, and Wyoming) have no personal income tax. ${ }^{350}$ State corporate income tax rates range from zero (Nevada, South Dakota, Washington, and Wyoming) to 12 percent in Iowa. ${ }^{351}$ States eschewing income taxes generally rely on some combination of sales taxes, property taxes, or levies on extractive industries. Because different sorts of taxation have important distributive effects, these revenue choices have significant policy implications across a range of issues.

States also vary significantly in their fiscal health. A prominent feature of American fiscal federalism is the national government's commitment not to bail out state governments when they get into trouble; this allows individual states to pursue their own distinctive fiscal policies without directly endangering the national finances. ${ }^{352}$ Although every state but Vermont has some sort of balanced budget amendment, these vary in form and (perhaps more importantly) the degree of accounting shenanigans that the state's political culture will tolerate. ${ }^{353}$ Moreover, states also vary in the extent to which they have incurred long-term debt obligations - such as unfunded public employee pension plans - that threaten the state's financial stability. ${ }^{354}$ Because state debt trades in welldeveloped financial markets, one can assess the variation in state fiscal soundness by looking at state credit ratings and the yields on state bonds. These measures reflect significant variation: In 2014, Standard \& Poors gave fifteen states had the prized AAA

${ }^{349}$ See Tax Policy Center, State Individual Income Taxes, 2015, Feb. 6, 2015, available at http://www.taxpolicycenter.org/taxfacts/displayafact.cfm?Docid=406. California millionaires pay an additional one percent, for a tip-top rate of 13.3 percent. See id.

${ }^{350}$ See id. New Hampshire does tax income from dividends and interest at five percent. See id.

${ }^{351}$ See Federation of Tax Administrators, Range of Corporate Income Tax Rates, Feb. 2014, available at http://www.taxadmin.org/fta/rate/corp_inc.pdf (for tax year 2014). In general, state taxation of businesses varies greatly in form, making crude rate comparisons less informative.

${ }^{352}$ See generally Jonathan A. Rodden, Hamilton's Paradox: The Promise and Peril of Fiscal Federalism (2006); Paul E. Peterson \& Daniel Nadler, Freedom to Fail: The Keystone of American Federalism, 79 U. CHI. L. REV. 253 (2012) .

${ }^{353}$ See generally National Council of State Legislatures, NCSL Fiscal Brief: State Balanced Budget Provisions, Oct. 2010, available at http://www.ncsl.org/documents/fiscal/StateBalancedBudgetProvisions2010.pdf.

${ }^{354}$ See, e.g., WhitNeY, supra note 247, at Ernest A. Young \& Emily D. Johnson, The Constitutional Law of State Debt, 7 Duke J. CON. L. \& PUB. POL'y 117 (2012). 
rating, while thirty-three were AA+, AA, or AA-. New Jersey, California, and Illinois were $\mathrm{A}+, \mathrm{A}$, and $\mathrm{A}-$, respectively. ${ }^{355}$

Practically speaking, these ratings affect the borrowing costs that each state faces; more broadly, they reflect a fairly thoroughgoing assessment of the state's financial prospects. State debts have been one of the great drivers of American constitutional history, from Chisholm v. Georgia ${ }^{356}$ and the ratification of the Eleventh Amendment, to the late-nineteenth century state bond crisis that shaped both the general federal common law and our law of sovereign immunity, ${ }^{357}$ to the partial revival of Contracts Clause litigation in our own time. ${ }^{358}$ Moreover, unmanageable state debts compound differences in tax and investment policy that, in turn, encourage migration from one state to another. As Ms. Whitney points out, "central-corridor states have more resources to attract newcomers because they are not choking on debt and crazy pension obligations and forced into a dependency on higher and higher tax rates. Not coincidentally, these same states are also investing in the right things: jobs, infrastructure, and education." $" 359$

Crime and Punishment: With respect to criminal law, "[t]he USA is not a coherent or singular state but rather made up of mixed democratic practices, a rich political imagination and varying sub-national polities-polities responsible for the

355 See State Credit Ratings from Standard \& Poor's, 2001-2014, Stateline, http://www.pewtrusts.org/en/research-and-analysis/blogs/stateline/2014/06/09/sp-ratings-2014 (visited Feb. 21, 2015).

${ }^{356} 2$ U.S. (2 Dall.) 419 (1793).

${ }^{357}$ See Ernest A. Young, Its Hour Come Round at Last? State Sovereign Immunity and the Great State Debt Crisis of the Early Twenty-First Century, 35 HARV. J. L. \& PUB. POL'Y 593, 593-94 (2012); Lucas A. Powe, Jr., Rehearsal for Substantive Due Process: The Municipal Bond Cases, 53 TEX. L. REV. 738 (1975).

${ }^{358}$ See Young \& Johnson, supra note 354, at 130-34. One need only look across the pond to see the significant of debt crises to a federal system. See, e.g., Paul P. Craig, Economic Governance and the Euro Crisis: Constitutional Architecture and Constitutional Implications, in THE Constitutionalization of European Budgetary Constraints (M. Adams, F. Fabbrini and P. Larouche eds 2014).

${ }^{359}$ WHITNEY, supra note 247, at 156. 
creation, enactment and implementation of nearly all criminal justice policy." ${ }^{360}$ Efforts to unify the substantive criminal law have seen mixed success at best. As William Stuntz has noted, "[n]o state adopted the Model Penal Code wholesale. Many of the states that copied it did so very partially, modifying some of its central elements. And, crucially, adoption of the MPC in no way restricted legislators' ability to add crimes later. They have continued to do so."

We see similar divergences in state punitive regimes. Persistent focus on national incarceration rates tends to mask substantial variation at the state level: "Minnesota, for example, imprisons 150 inmates per 100,000 population, New York imprisons 343 inmates per 100,000 population, both below the national rate of 429 inmates per 100,000 population and well below Texas' 692 inmates per 100,000 population or Louisiana's 803 inmates per 100,000 population."362 These rates have not remained static; a variety of states have significantly altered their imprisonment rates in recent years, with varying results. ${ }^{363}$ Texas, for example, has launched an ambitious effort to develop alternatives to incarceration, saving billions of dollars and also seeing significantly reduced crime rates. ${ }^{364}$ Scholars have traced these variations in incarceration to differences in the structure of state government and practices of civic engagement. ${ }^{365}$

\footnotetext{
${ }^{360}$ Vanessa Barker, The Politics of Punishing: Building a State Governance Theory of American Imprisonment Variation, 8 PUNISHMENT \& SOCIETY 5, 6 (2006).

${ }^{361}$ William J. Stuntz, The Pathological Politics of Criminal Law, 100 Mich. L. ReV. 505, 583 (2001); see also Paul H. Robinson \& Markus D. Dubber, The American Model Penal Code: A Brief Overview, 10 NEw CRIM. L. REV. 319, 320 (2007) (commenting that, notwithstanding the influence of the Model Penal Code, "[t]here is much diversity among the fifty-two American criminal codes and, therefore, it is often difficult to state 'the' American rule on any point of criminal law").

${ }^{362}$ Barker, supra note 360 , at 5 .

${ }^{363}$ See Oliver Roeder, The Imprisoner's Dilemma, Five Thirty Eight, Feb. 12, 2015, available at $\mathrm{http} / /$ fivethirtyeight.com/features/the-imprisoners-dilemma/.

${ }^{364}$ See Roeder, supra note 363 (chart noting a 20 percent drop in Texas prison population and a roughly 27 percent drop in crime); see generally Olivia Nuzzi, Prison Reform is Bigger in Texas, THE DAILY BEAST, April 12, 2014, available at http://www.thedailybeast.com/articles/2014/04/12/prison-reform-is-bigger-in-texas.html.

${ }^{365}$ Barker, supra note 360 , at 6 .
} 
One of the most studied areas of divergence is capital punishment. As one study noted, "[s]tate policy toward the death penalty varies widely in both theory and practice . . . [M]any U.S. states have no death penalty in their criminal codes; others have legislation on the books but do not conduct any executions; and a small number of states conduct the majority of executions." enormous variation in the rates. Texas and Virginia, for example, execute more than eleven persons per million population, while seven states (Ohio, Tennessee, Colorado, California, Pennsylvania, Kentucky, and Washington) execute less than one in a million. ${ }^{367}$ To the extent that the law of capital punishment has become more uniform in recent years, that uniformity has been largely imposed by the Supreme Court's interpretation of the Eighth Amendment. ${ }^{368}$

Environmental Policy: Although federal law dominates environmental policy, it typically works through cooperative federalism arrangements wherein federal agencies set overall standards and states have primary authority over enforcement. Hence, "states play a central role in environmental enforcement, and have enormous discretion to determine their own enforcement strategies." ${ }^{369}$ And states still retain significant independent authority to regulate issues not covered by federal mandates or, in some

${ }^{366}$ Franklin E. Zimring, The CONTRAdictions of AMERICAN CAPITAl PUNishment 72 (2003). As of this writing, thirty-two states have the death penalty on the books, while eighteen have abolished it. States With and Without the Death Penalty, Death Penalty Information Center, http://www.deathpenaltyinfo.org/states-and-without-death-penalty (visited Feb. 20, 2015).

${ }^{367}$ See ZIMRING, supra note 366, at 73, Figure 4.2 (figures are for 1977-2000, and I have excluded states from Zimring's chart that have since abolished the death penalty). Although Professor Zimring notes "a pronounced regional pattern associated with variations in death penalty policy among U.S. states," $i d$. at 73, region does not seem to be a good indicator of the rate among states that actually $d o$ execute people; for example, Virginia executes far more people than North Carolina or Georgia; Arizona and Missouri execute far more than California or Indiana. See id., Figure 4.2.

${ }^{368}$ See, e.g., Roper v. Simmons, 543 U.S. 551 (2005) (eliminating significant state-by-state variation on availability of the juvenile death penalty).

${ }^{369}$ David M. Konisky \& Neal D. Woods, Environmental Policy, in Politics IN THE AmERICAN States: A Comparative ANAlysis 469, 480 (Virginia Gray, Russell L. Hanson, \& Thad Kousser eds. 10th ed. 2013); see also John P. Dwyer, The Practice of Federalism Under the Clean Air Act, 54 MD. L. REV. 1183 (1995). 
important areas, to exceed federal requirements. ${ }^{370}$ One recent overview found "tremendous variation in state policy" on environmental issues. ${ }^{371}$ This variation includes wide divergence in per capita spending on environmental policies, ${ }^{372}$ inspection rates for pollution sources, ${ }^{373}$ and willingness to innovate or to exceed federal requirements. ${ }^{374}$

A number of factors drive these variations, including variations in environmental conditions, fiscal resources, administrative capacity, political attitudes of the electorate, partisan control of the state government, and federal activity in the state. ${ }^{375}$ Divergent environmental policies in turn affect not only the quality of the environment, but also economic growth and development. California's economic future, for example, may well turn importantly on state-level environmental choices about hydraulic fracturing and development of the Monterey Shale. ${ }^{376}$

${ }^{370}$ See, e.g., Konisky \& Woods, supra note 369 , at 484-85 (discussing California's statutory waiver authorizing it to exceed federal motor vehicle emissions standards under the Clean Air Act); $i d$. at 485 (noting that "[i]n the absence of strong federal policy activity [on global warming], many states have adopted measures to either directly or indirectly reduce greenhouse gas emissions"). On the other hand, twenty-four states have legislative prohibited their environmental agencies from adopting standards more stringent than federal requirements. See id. at 491.

${ }^{371}$ Konisky \& Woods, supra note 369 , at 480.

${ }^{372}$ See Konisky \& Woods, supra note 369 , at 482 (ranking expenditures and observing that "the states at the top of the list [Hawaii, West Virginia, Delaware, New Hampshire, and Wyoming] ... are spending well over $\$ 100$ per citizen compared with the states at the bottom of the rankingsOhio, Colorado, Alabama, Georgia, and Oklahoma - each of which is spending less than $\$ 20$ per citizen”).

${ }^{373}$ Konisky \& Woods, supra note 369 , at 482.

${ }^{374}$ Konisky \& Woods, supra note 369 , at 484-92.

${ }^{375}$ Konisky \& Woods, supra note 369, at 492-93; Scott P. Hays, Michael Esler, \& Carol E. Hays, Environmental Commitment among the States: Integrating Alternative Approaches to State Environmental Policy, 26 PuBlius 41 (1996).

${ }^{376}$ See Jason Hoppen, State to Examine Monterey Shale Potential, SANTA CruZ Sentinel, Jan. 14, 2015, available at $\mathrm{http} / / / \mathrm{www}$. santacruzsentinel.com/general-news/20150114/state-toexamine-monterey-shale-potential; Norimitsu Onishi, Vast Oil Reserve May Now Be Within Reach, And Battle Heats Up, N.Y. TIMES, Feb. 3, 2013, available at http://www.nytimes.com/2013/02/04/us/vast-oil-reserve-may-now-be-within-reach-and-battleheats-up.html?pagewanted $=$ all\& $\mathrm{r}=0$. 
Beyond policy divergence within states, particular states have often taken the lead in developing environmental policies that influence the nation as a whole. California, for example, historically preceded the federal government in combating air pollution, and that leadership role resulted in a special provision in the federal Clean Air Act permitting California to establish stricter limits on motor vehicle emissions than national law would otherwise permit. ${ }^{377}$ Building on this exemption, California has undertaken to lead in addressing climate change by regulating greenhouse gas emissions more stringently than does federal law. ${ }^{378}$ Other states have also embarked on important environmental initatives. Ten northeastern and mid-Atlantic states have formed the Regional Greenhouse Gas Initiative, ${ }^{379}$ an agreement by to establish a regional cap and trade program for electric generating plants.

Perhaps nothing shows the diversity of state positions on environmental matters better, however, than recent litigation over federal greenhouse gas standards. Twelve states successfully sued the EPA seeking to force it to regulate greenhouse gases as pollutants under the Clean Air Act. After they prevailed in the Supreme Court, ${ }^{380}$ the EPA designated six gases as pollutants - only to be challenged by the states of Alabama, Texas, and Virginia. Eighteen states intervened in support of the EPA, while fourteen other states intervened in support of the challengers. ${ }^{381}$

${ }^{377}$ See 42 U.S.C. $\$ 7543$ (b), (e). EPA must approve the higher standards, and other states are permitted to adopt the California standards once approved. See also Dwyer, supra note 369, at 1196 n.65 (explaining that this exception responded to California's history of leadership on air pollution regulation).

${ }^{378}$ See Chris Megerian, California Leaders Vow to Continue Climate Change Action, L.A. TIMES, Dec. 15, 2014, available at http://www.latimes.com/local/politics/la-me-pol-brown-climate20141216-story.html.

${ }^{379}$ Regional Greenhouse Gas Initiative, http://www.rggi.org/home (visited October 29, 2010).

${ }^{380}$ Massachusetts v. EPA, 549 U.S. 497 (2007).

${ }^{381}$ See Robin Bravender, States Take Sides in Greenhouse Gas 'Endangerment' Brawl, N.Y. TIMES, March 19, 2010, available at http://www.nytimes.com/gwire/2010/03/19/19greenwirestates-take-sides-in-greenhouse-gas-endangerme-29019.html. In the end, the District of Columbia Circuit rejected the challenge. See Coalition for Responsible Regulation, Inc. v. EPA, 684 F.3d 102 (D.C. Cir. 2012). 
One could proliferate examples. Numerous studies of other policy fields have found persistent state-by-state variation in policy outcomes. ${ }^{382}$ The diversity in policy inputs, in other words, is likewise reflected in policy outputs.

\section{The Red and the Blue}

Many Americans may not remember that the red states used to be blue, and vice versa. When NBC unveiled the first illuminated electoral map on election night in November 1976, the states voting for Republican Gerald Ford were blue- the color of the Union in the Civil War-and the states voting for Democrat Jimmy Carter were red. ${ }^{383}$ For several election cycles afterwards, different networks used different color schemes. But by 2000 political commentators had settled into the now-standard labels of Republican states as "red" and Democratic states as "blue." 384 These labels have become central to a large debate, among both academics and popular commentators, as to whether the nation is becoming polarized along state lines. One writer, for example, asserted that red and blue states embody "two different forms of government, based on two different visions of the social contract.",385

There is little doubt that American politics are becoming more polarized in some respects. A recent Pew Center survey found that "Republicans and Democrats are more divided along ideological lines-and partisan antipathy is deeper and more extensive-

\footnotetext{
${ }^{382}$ See, e.g., Martha Derthick, American Federalism: Madison's Middle Ground in the 1980s, 47 PuB. ADMIN. REV. 66, _ (1987) (concluding, based on a study of state administration of welfare programs, that "federalism lives ... in the persistence of interstate differences in program characteristics and in the ineffectiveness of much federal oversight of state administration"); see generally Phillip W. Roeder, Public Opinion ANd Policy Leadership IN THE AMERICAN STATES 27 (1994) ("Overall, previous research finds little evidence that state policymaking has become nationalized.").

${ }^{383}$ See Ron Elving, The Color of Politics: How Did Red and Blue States Come to Be? NPR, Nov. 13, 2014, available at http://www.npr.org/2014/11/13/363762677/the-color-of-politics-how-didred-and-blue-states-come-to-be.

${ }^{384}$ See id.

${ }^{385}$ Jonathan Cohn, Blue States are from Scandinavia, Red States are from Guatemala, THE NEW REPUBLIC, Oct. 5, 2012, available at http://www.newrepublic.com/article/politics/magazine/108185/blue-states-are-scandinavia-redstates-are-guatemala.
} 
than at any point in the last two decades. ${ }^{\text {386 }}$ But debate continues about whether citizens are polarized in the sense of having more extreme views or simply in the sense of having more ideologically consistent views, ${ }^{387}$ and about whether polarization is largely confined to elites or pervasive throughout the public. ${ }^{388}$ The important question for my purposes is whether political polarization is a geographic phenomenon, tending to differentiate states from one another. ${ }^{389}$

Debate persists on this point, too. ${ }^{390}$ At least two issues seem potentially important. First, do the differences dividing the electorate track state lines, so that the stereotypes of red states and blue states actually do signify meaningful differences? Some evidence suggests that they do. Alan Abramowitz and Kyle Saunders have noted, for example, that "states have become much more sharply divided among party lines since the 1960s: red states have been getting redder while blue states have been getting bluer.

\footnotetext{
${ }^{386}$ Michael Dimock, Joceleyn Kiley, Scott Keeter, \& Carroll Doherty, Political Polarization in the American Public: How Increasing Ideological Uniformtiy and Partisan Antipathy Affect Politics, Comprmise and Everyday Life, at 6 (June 12, 2014), available at http://www.peoplepress.org/files/2014/06/6-12-2014-Political-Polarization-Release.pdf.

${ }^{387}$ See, e.g., Morris Fiorina, Americans Have Not Become More Politically Polarized, WASH. Post, June 23, 2014, available at http://www.washingtonpost.com/blogs/monkeycage/wp/2014/06/23/americans-have-not-become-more-politically-polarized/ (arguing that only the latter is true); see also Alan I. Abramowitz \& Morris P. Fiorina, Polarized or Sorted? Just What's Wrong With Our Politics, Anyway? The AMERICAn InTEReSt, March 11, 2013, available at http://www.the-american-interest.com/2013/03/11/polarized-or-sorted-just-whats-wrong-withour-politics-anyway/\# ftnref10 (exchange between Professors Abramowitz and Fiorina).

${ }^{388}$ Compare, e.g., Morris P. Fiorina with Samuel J. Abrams \& Jeremy C. Pope, Culture War? The Myth of A Polarized America 167-70 (2d ed. 2006) (arguing that polarization is largely an elite phenomenon), with Alan I. Abramowitz \& Kyle L. Saunders, Is Polarization a Myth?, 70 J. POL 542, 543 (2008) (arguing it is more pervasive).

${ }^{389}$ See, e.g., SCHAPIRO, supra note 13, at 29 (arguing that because the better empirical evidence suggests that red and blue states are not as polarized as the election night maps make them seem, this demonstrates that states no longer represent distinctive communities of value).

${ }^{390}$ Compare, e.g., FIORINA, supra note 388, at 33-56 (finding no fundamental differences between red and blue states), with Abramowitz \& Saunders, supra note 388, at 549 (finding "large differences between the social characteristics and political attitudes of red state voters and blue state voters").
} 
While the 2000 and 2004 presidential elections were highly competitive at the national level, the large majority of states were not competitive."

Others have suggested that a focus on political outcomes may exaggerate the extent of polarization, however. ${ }^{392}$ Matthew Levendusky and Jeremy Pope have argued that "scholars need to look at the entire distribution of opinion in red and blue states," rather than simply the average opinion in those states or the outcomes of elections in each jurisdiction. ${ }^{393}$ Based on data showing the distribution of opinions, they found that "[e]ven with relatively extreme states such as New York and Utah, the level of overlap is striking." 394 Moreover, one cannot reliably predict the ideology of a particular person based on their state: "although blue-state citizens are on average more liberal, they are not uniformly more so-indeed, it is basically a coin flip to determine which respondent (the red- or the blue-state resident) is more liberal. ${ }^{395}$ The upshot is that multiple approaches to measurement "show a great deal of commonality between red and blue states, with much more common ground than division between the two groups."

Significant evidence suggests that, to the extent that polarization does occur, it may be occurring primarily within states rather than between them. Bill Bishops's prominent work on "The Big Sort" argues that red and blue states are less significant than "landslide counties" with disproportionate majorities for one party or the other that remain stable over time. ${ }^{397}$ Others have argued that the key divides are between urban and

\footnotetext{
${ }^{391}$ Abramowitz \& Saunders, supra note 388, at 548.

${ }^{392}$ See, e.g., GELMAN, supra note 49, at 31 (pointing out that "most of the states are not far from evenly divided").

${ }^{393}$ Matthew S. Levendusky \& Jeremy C. Pope, Red States vs. Blue States: Going Beyond the Mean, 75 PUB. OPINION Q. 227 (2011).

${ }^{394} I d$. at 238 .

${ }^{395} I d$. at 237. See also Elving, supra note 383 (observing that liberals exist in Idaho while conservatives soldier on in Minnesota, and that "being on the minor-fraction side of the party balance does not make these citizens less Idahoan or less Minnesotan. On the contrary, they may be among the fiercest loyalists of either state").

${ }^{396}$ Levendusky \& Pope, supra note 393, at 237.

${ }^{397}$ See Bishop, supra note _, at __; see also Martin W. Lewis, Does the Red-State/Blue-State Model of U.S. Electoral Politics Still Work? GeoCurrents, Nov. 13, 2014, available at http://www.geocurrents.info/geopolitics/elections/red-stateblue-state-model-u-s-electoral-politics-
} 
rural areas. ${ }^{398}$ From the perspective of this data, states may be important not so much because they are distinctive in themselves, but rather because they provide an institutional space where citizens with divergent views and local identities must mix and govern together.

A second potentially important question concerns the extent to which in-state politics reflects national politics. Professor Fiorina notes that "in 2004 seven of the top eight Kerry states had Republican governors, while nine states that Bush carried by double-digit margins had Democratic governors. ${ }^{, 399}$ Moreover, Fiorina points out that in 2004, "Bush carried [Montana] by 20 points and Montanans passed a gay marriage prohibition by a 67:33 margin"; nonetheless, the same state in the same year also elected a Democratic governor, flipped the state Senate from Republican to Democratic control, and passed a medical marijuana initiative by a broad margin. ${ }^{400}$ These sorts of outcomes suggest that, in at least some states, different forces are driving political outcomes at the state and national levels ${ }^{401}$ - which in turn suggests that state politics has a certain degree of autonomy and distinctiveness.

still-work (noting that county-level data show "many 'red' areas in most 'blue' states, just as there are quite a few 'blue' zones in most 'red' states").

${ }^{398}$ See, e.g., Lewis, supra note 397 (“Outside of New England [and] the Pacific Coast, few nonmetropolitan [congressional] districts without Hispanic or African-American majorities supported Democratic candidates."); Philip Bump, There Really Are Two Americas. An Urban One and a Rural One., WASH. POST, Oct. 21, 2014, available at http://www.washingtonpost.com/blogs/thefix/wp/2014/10/21/there-really-are-two-americas-a-urban-one-and-a-rural-one/; Richard Morrill, How Polarization Plays Out in Washington State: Voting for President and the Same-Sex Marriage, NEWGEOGRAPHY, Jan. 15, 2013, available at http://www.newgeography.com/content/003400-how-polarization-plays-out-washington-state-

voting-president-and-same-sex-marriage (showing urban-rural divide as the "dominant" dimension).

${ }^{399}$ FIORINA, supra note 388, at 31.

${ }^{400} I d$.

${ }^{401}$ See Lewis, supra note 397 (noting that in "non-national elections, Republicans can be more competitive in 'blue' states just as Democrats can be more competitive in 'red' states, as they can run on platforms to the left and right, respectively, of their national parties"); Levendusky \& Pope, supra note 393, at 243 (concluding that "enterprising politicians can construct different types of governing coalitions in the same state. New York and California can elect Republican governors, while Montana and Wyoming can elect Democratic governors"). 
A broader point about the independence of state politics may help us assess the evidence on partisan polarization in the states. Even assuming a good deal of overlap in political opinions between red states and blue states, the fact that variation in the average opinions is sufficient to swing elections one way or the other may play an important role in bolstering distinctive state identities. That is because identity is not necessarily preexisting or even static, but rather may be built through the operation of politics. The fact that Republicans tend to win most statewide elections in red states, and Democrats win in blue states, does affect how those states are governed. And the experience of participation in governance, as well as the content of the laws, may shape citizens' identity with the state.

In the wake of the 2012 election, for example, thirty-seven states had unified party control of the state legislature and governor's office-more than in any year since 1952. ${ }^{402}$ That number declined slightly in $2014,{ }^{403}$ but the fact remains that many states are not gridlocked like our national government. This difference may be important for a number of reasons. States may be able to experiment and innovate more freely than the national government, and participation at the state level may be less frustrating. Moreover, Anna Stilz has emphasized the role of democratic participation in legislation in shaping a regime that "reflects [citizens'] common life together" and "constitut[ing] a group of citizens into a collective with important ties binding them together." ${ }^{, 404}$ If that is true, then the crucial question is not so much whether the citizens of particular states bring different characteristics into the voting booth, but rather whether the outcomes of elections-and of the legislative process they shape-contribute to the distinctive identities of these political communities over time.

\footnotetext{
${ }^{402}$ Josh Goodman, One-Party Control Comes with Power and Peril, Stateline, Dec. 6, 2012, available at http://www.pewstates.org/projects/stateline/headlines/one-party-control-comes-withpower-and-peril-85899434570.

${ }^{403}$ See Mark Trumbull, The Color Purple: Republican Gains Mean Divided Government in Many States, CHRISTIAN SCIENCE MONITOR, Nov. 7, 2014, available at http://www.csmonitor.com/USA/Elections/2014/1107/The-color-purple-Republican-gains-meandivided-government-in-many-states (concluding that "as many as 19 states will have power split between political parties").

${ }^{404}$ Stilz, supra note 306 , at 260.
} 


\section{State Identity}

Since the 1990s, North and South Carolina have been working to re-establish the original boundary between two states, which had become slightly misplaced over the centuries as the original trees and stones used to mark the border shifted and eroded. ${ }^{405}$ Using a combination of historical research and GPS technology, surveyors have now discovered that about thirty households (and a gas station) are in a different state than their inhabitants originally thought. This revelation has caused considerable consternation, much of it for readily-apparent economic reasons; the gas station, for example, will have to stop selling fireworks and increase its gas prices by roughly thirty cents per gallon on account of higher taxes in North Carolina. ${ }^{406}$ But for some, the objection sounds in less tangible notions of identity. Said one newly-designated North Carolinian, "I was born a sandlapper and I want to remain a sandlapper. And there is no way in hell I am rooting for the Tar Heels."

Unfortunately, we cannot move large samples of the populace from one state to another and see if they complain. The existence and strength of state identity generally will have to be measured - if it even can be measured-in some other way. Direct surveys on the matter may well be practicable; in Europe, where the future of political and economic integration may depend on the extent to which Frenchmen and Germans

${ }^{405}$ See Kim Severson, Untangling a Border Could Leave a Mess for Some, N.Y. TIMES, April 4, 2012, available at http://www.nytimes.com/2012/04/05/us/the-carolinas-work-to-clarify-theirborders.html.

${ }^{406} I d$.

${ }^{407}$ Jeffry Collins, NC, SC state line isn't where folks thought it was, MSN.COM, March 23, 2012, available at http://www.msnbc.msn.com/id/46832892/ns/us_news-life/\#.T4XV2Kvy9fF. What on earth is a "sandlapper?" you ask. It is a nickname for South Carolinians, referring primarily to those from the sandy-soiled regions of central and eastern South Carolina. South Carolina-Origin of the Term Sandlapper, SCIWAY, available at http://www.sciway.net/hist/sandlapper.html (visited April 11, 2012). The term's origins are disputed, but may stem not only from the sandy soil but also from the clay-eating practices of certain economically-disadvantaged residents. See $i d$. The North Carolinian nickname "tar heel" is better known but similarly obscure in its origins. See Tar Heel, WikIPEDIA, available at http://en.wikipedia.org/wiki/Tar_Heel (visited April 11, 2012). Of course, those North Carolinians who prefer their basketball in a darker shade of blue tend to share the sandlapper's sentiments quoted in the text. See Urban Dictionary, GTHC, http://www.urbandictionary.com/define.php?term=GTHC, visited Sept. 17, 2014 (explaining the significance of the acronym "GTHC"). 
can be persuaded to identify as "Europeans," frequent polls seek to measure the relative strength of various political identities. ${ }^{408}$ Alas, I am unaware of any such survey data for the United States.

The previous part examined state distinctiveness as a proxy for identity. But as the Anna Karenina principle suggests, distinctiveness and identity are not the same thing. And even if we were willing to presume that citizens would identify with their states in a world where the states are sharply distinctive, it is not at all clear that the more modest differences discussed in the preceding section would warrant a similar presumption. Conversely, the Carolina border example suggests that one might identify with one's state just because it happens to be one's home, even if the state next door is pretty similar. Certainly the relative similarity of high schools in a given school district does not keep the fans from screaming at a Friday night football game. ${ }^{409}$ This section thus tries to identify some additional proxies for state identity. I consider three: the extent to which states make an effort to shape and communicate a common history, particularly through public education; public opinion data on trust in government; and the extent and impact of individual mobility among states.

\section{A. State History and Public Education}

One way to assess the continuing force of state identity is to examine the extent to which citizens of a state share a common past-as well as to the efforts of the state itself to construct and transmit that past. Consider this famous passage from William Faulkner's Intruder in the Dust:

For every Southern boy fourteen years old, not once but whenever he wants it, there is the instant when it's still not yet two o'clock on that July afternoon in 1863 , the brigades are in position behind the rail fence, the guns are laid and ready in the woods and the furled flags are already loosened to break out and Pickett himself with his long oiled ringlets and his hat in one hand probably and his sword in the other looking up the hill waiting for Longstreet to give the word and it's all in the balance, it hasn't happened yet . . . and that moment doesn't need even a fourteenyear-old boy to think This time. Maybe this time with all this much to

\footnotetext{
${ }^{408}$ See, e.g., European Commission, Eurobarometer 71: Future of Europe, Jan. 2010, at 34-50; RISSE, supra note 109, at _ (collecting polling data).

${ }^{409}$ See, e.g., H.G. Bissinger, FridAy Night Lights: A Town, A TeAm, AND A DreAm (1990).
} 
lose and all this much to gain: Pennsylvania, Maryland, the world, the golden dome of Washington itself to crown with desperate and unbelievable victory the desperate gamble, the cast made two years ago. . 410

This summation of the "Lost Cause" myth that "shaped the mentalité of generations of white southerners" $" 411$ illustrates both the power of collective memory to shape political identity and the peril associated with such memory. ${ }^{412}$ "Collective memory, constructed through such activities as the writing and teaching of history, the celebration of holidays, the creation of art, the building of monuments and museums, and the preservation of historical sites, gives a society its identity and helps to define its values."

It is easy to think of states that share importantly distinctive historical experiences. Texas, of course, has its own revolutionary experience and decade of national independence, as well as roles in the Civil War and the Western frontier. ${ }^{414}$ As Debbie Nathan puts it, "You know the tale: noble Jim Bowie against the evil Santa Anna, greedy Yankee Carpetbaggers versus vanquished and suffering Confederates, valiant

${ }^{410}$ William FAULKNER, INTRUder IN THE DUST 148-49 (Signet, New American Library ed., 1948).

${ }^{411}$ MCPHERSON, supra note 116, at 71.

${ }^{412}$ I discuss the dangers associated with strong subnational identities in Part VI, infra. The "Lost Cause" myth, of course, is a regional myth — not one associated with a particular state. I argue in Part V, however, that regional identities tend to be experienced and acted upon primarily through states. See infra text accompanying notes

${ }^{413}$ Gregg Cantrell, The Bones of Stephen F. Austin: History and Memory in Progressive-Era Texas, in Gregg Cantrell \& Elizabeth hayes Turner, eds., Lone Star Pasts: Memory AND HISTORY IN TEXAS 39, 41 (2007). It may not be entirely irrelevant to note that I found this book at the Alamo gift shop in San Antonio.

${ }^{414}$ See, e.g., GUNTHER, supra note 197, at 6 ("The fact that Texas was an independent state, albeit briefly, is an inescapable reality to most Texans; it is the cause of what we will later describe as 'Texan nationalism'; a visitor to Texas is reminded of it ceaselessly."); but see T. R. FEHRENBACH, LONE STAR: A History OF TEXAS AND THE TEXANS 255-57 (2d ed. 2000) (emphasizing the frontier experience as more critical than the Revolution or period of independence to the formation of Texas culture). 
Rangers fighting perfidious Injuns and Mexicans." 415 "Because of this history,” T. R. Fehrenbach observes, "the dominant Texan viewpoint was not that Texans settled Texas, but they conquered it. . . . The struggle, the violence, the tribal instincts, and the feeling for place that these engendered may have separated Texans in some ways from other North Americans." ${ }^{, 416}$ Hence, "[t]he Texans came closest to creating, in America, not a society but a people, like the peoples who had come before them." ${ }^{417}$ As Cristina Henriquez puts is, "saying you're a Texan isn't just telling someone where you're from; it's telling someone who you are." 418

Texas may have a particularly distinctive history, but it is hardly alone. Consider also the Puritan experience in Massachusetts, the California Gold Rush, the Oregon Trail, New Mexico's Spanish and Native American heritage, and Hawaii's native monarchical past. And if one looks more closely, one often finds that even states that seem to outsiders to lack such distinctive pasts nonetheless find in their particular history a collective memory worth preserving. While it is hard to measure directly citizens' sense of and attitude toward a distinctive collective past, we can identify positive state actions directed toward preserving and shaping that past. And it seems safe to assume that elected state officials would not pursue such efforts if their constituents were indifferent to them.

${ }^{415}$ Quoted in Laura Lyons McLemore, Early Historians and the Shaping of Texas Memory, in CANTRELL \& TURNER, supra note 413, at 15, 16; see also Ivins, supra note 200, at 425 (describing the Alamo as Texas's "founding myth"). It is worth noting, however, that these collective memories are not unitary, even within a single state. Tejanos and African-Americans would tell a different tale. See Gregg Cantrell \& Elizabeth Hayes Turner, Introduction: A Study of History, Memory, and Collective Memory in Texas, in CANTRELl \& TURNER, supra note 413, at 1, 5 (observing that "various groups of Texans ... do not share one experience; rather, they share multiple 'collective memories' of Texas' past"). The important point for present purposes, however, is that each of these multiple collective memories is distinctively Texan. See, e.g., Andres Tijerina, Constructing Tejano Memory, in CANTRELl \& TURNER, supra note 413, at 176, 178-80 (distinguishing the very term "Tejano"- "any Spanish-surnamed Texans whose historical or cultural roots are in Texas"-from "Mexican Americans" and "Latinos" and concluding that "[b]y using the term 'Tejano,' Hispanics of various national origins can relate to a common heritage as Texans").

${ }^{416}$ FEHRENBACH, supra note 414, at 447-48.

${ }^{417}$ Id. at 256.

${ }^{418}$ Cristina Henriquez, Texas, in StAte By StAte, supra note 3, at 436, 442. 
States undertake to promote collective memory by erecting monuments, preserving historical sites, and a host of similar activities. These acts may be aimed not only a preserving the state's heritage generally, but more specifically at constructing a particular version of that past in order deliberately to shape current identity in a way that furthers contemporary policy goals. For example, Gregg Cantrell has recounted how a Progressive-era governor of Texas, Oscar Branch Colquitt, deliberately set out to revive collective memories of the Texas Revolution at the same time as he de-emphasized Texas's identity as part of the old Confederacy. "If Texas were to become the modern state that boosters like Oscar Branch Colquitt envisioned," Professor Cantrell writes, "it needed to shed the burden of southern history and pick up the sword of Texas historynot just any old Texas history, but a version of the revolutionary past that would reflect the progressive values and aspirations of modernizing society." ${ }^{419}$ Governor Colquitt pursued this end by building monuments, appropriating money to preserve the Alamo historical site, and even exhuming the body of Stephen F. Austin and reburying him, with great fanfare, on the "Hill of Heroes" in the State Cemetery in the capitol city bearing his name. ${ }^{420}$ These efforts to turn the state's identity away from the depressing legacy of the Confederacy's "Lost Cause" were largely successful. "Even today . . . the dominant symbols - and hence the dominant public memories - of Texas history continue to be western symbols: the pioneer (symbolizing self-sufficiency), the Alamo (valor), the cowboy (rugged individualism), and the wildcatter (entrepreneurial spirit)." ${ }^{, 21}$

Almost every state provides for the teaching of state history, either by law or by inclusion in the state Board of Education's prescribed standards and curriculum. Over half of the states provide for state history as a separate course. Thirty states currently require schools to offer such courses by statute, ${ }^{422}$ a number that has nearly doubled over the past eighty years. ${ }^{423}$ North Carolina, for example, provides by statute that

${ }^{419}$ Cantrell, supra note 413 , at 66 . See also Cantrell \& Turner, supra note 415 , at 6 ("By the beginning of the twentieth century ... Texans were turning to a more useful past, one that brought bravado and glory to their field of memories. Hence 'Remember the Alamo' replaced the rebel yell, at least superficially.").

${ }^{420}$ See Cantrell, supra note 413, at 37-64.

${ }^{421}$ Id. at 67.

${ }^{422}$ [cites] Moreover, forty-six states require state history as part of their state curriculum. [cites]

${ }^{423}$ See C.P. Smith \& J.L. Hupp, The Teaching of State History in the United States, 5 EdUC. ReS. BULl 66, 68, table II (1926). 
Both the standard course of study and the Basic Education Program shall include the requirement that the public schools provide to all students one yearlong course of instruction on North Carolina history and geography in elementary school and one yearlong course of instruction in middle school on North Carolina history with United States history integrated into this instruction. The course of instruction shall include contributions to the history and geography of the State and the nation by the racial and ethnic groups that have contributed to the development and diversity of the State and nation. Each course of instruction may include up to two weeks of instruction relating to the local area in which the students reside. ${ }^{424}$

Any parent can attest, of course, that simply telling middle-schoolers they're supposed to care about something will hardly make it so. But the presence of these statutes on the books, and their increasing prevalence over the course of the last century, must reflect a significant degree of political consensus that state history is important. Moreover, leading writers on nationalism have stressed the importance of education in shaping and preserving national identities. ${ }^{425}$ Efforts by states to promote the teaching of state history seem likely to play an analogous role in promoting some level of individual identification with the states.

Public education also serves a more foreward-looking role in creating and maintaining a sense of state identity. This is particularly true in higher education, where a public university of the first rank can serve as a focal point for the state community. Writing in the Federal Writer's Project guide to North Carolina, for example, Jonathan Daniels observed that the University of North Carolina functioned to "create a unity" out of the diverse elements and regions of the state. ${ }^{426}$ It did this in part by creating "an aristocracy of intelligence" and "a group of men in every section of the State who have

\footnotetext{
${ }^{424}$ N.C. G.S.A. $§ 115 \mathrm{C}-81$ (b1). My then-eighth-grader reported that this requirement is sometimes honored in the breach by teachers wishing to emphasize national history, but even such teachers seem committed to including a significant element of distinctive state history in the curriculum.

${ }^{425}$ See, e.g., SMITH, supra note 94, at 16.

${ }^{426}$ Jonathan Daniels, Tar Heels All, in Federal Writers' ProjeCt, North CAROLINA: THE WPA Guide to the Old North State 3, 6 (rev. ed. 1988) (1939)
} 
something more than a provincial's sense of the meaning of his native land." 427 Even more important, because the state had been "so long in ignorance, so long in poverty," "[t]he university at Chapel Hill serves as a symbol for unity in aspiration as do few other institutions in the country." 428

One could tell similar stories about public universities in other states. ${ }^{429}$ President Mark Yudof of the University of California, for example, introduced the university's budget by noting that "[t]he University of California grew up with the state and for a century-and-a-half has served as a beacon of hope, an agent of transformation, and a true source of pride for all Californians. ${ }^{, 430}$ State universities' public role may be especially salient in the modern era when these universities (and especially their athletic programs) have become massive institutions with equally massive marketing and branding operations. ${ }^{431}$ How many Americans who have never attended a public university nonetheless feel a part of the state community when rooting for the Longhorns or the Buckeyes or the Wildcats? Congratulating the Ohio State football team on winning the

\footnotetext{
${ }^{427} I d$.
}

${ }^{428} I d$.

${ }^{429}$ See, e.g., Bruce Rastetter \& Larry McKibben, Strengthening Iowa's Higher Education Legacy, http://efficiency.uiowa.edu/ (visited Feb. 20, 2015) (“Over the years, Iowa's public universities have instilled knowledge in our young people and pride throughout our state. Education became an Iowa identity - a distinction forged over time by strong Midwestern sensibilities and our unwavering commitment to academic excellence.") (statement by members of the state's Board of Regents initiating an institutional review of the state's three public universities).

${ }^{430}$ Mark Yudof, Message from the President, UNIVERSITY OF CALIFORNIA BUdGET FOR CURRENT OPERATIONS, 2013-14, at S-1 (Oct. 2012), available at http://regents.universityofcalifornia.edu/regmeet/nov12/flattach3.pdf.

${ }^{431}$ The Ohio State University's branding website, for example, includes a dizzying array of detailed guidelines for presenting the University to the public. See http://brand.osu.edu/ (visited Feb. 20, 2015). And its account of "our brand" stresses the University's relation to the Ohio community and its "Midwest sensibility." See http://brand.osu.edu/our-brand/ (visited Feb. 20, 2015). 
national college football championship in 2015, Governor John Kasich commented that "[y]ou really lifted almost the entire state."432

\section{B. Trust in Government}

Researchers have been asking survey questions about trust in government for many decades, and these questions have generally included a comparative component that inquires whether citizens repose more trust in state or national institutions. This research concludes that "[c]itizens on average evaluate the performance of the federal government as significantly lower than that of the state and local governments, report less faith in the federal government to 'do the right thing,' have significantly lower confidence in the ability of the federal government to solve problems effectively, see the federal government as significantly less responsive than lower levels of government, and nearly 60 percent see the federal government as the most corrupt level of government."

As Megan Mullin has pointed out, “[t]he public's affection for an institution is not necessarily consistent with its assessment of that institution's performance, and it is not clear what relationship either of these opinions has with attitudes about the abstract principle related to the division of power., ${ }^{, 34}$ On the other hand, a number of recent studies have emphasized the importance of trust to government policy and social cohesion. Marc Hetherington has demonstrated the importance of public trust in government to mobilizing public support for any policy involving sacrifice on behalf of

${ }^{432}$ Randy Ludlos, Kasich Welcomes Ohio State Championship Team to Statehouse, THE
Columbus $\quad$ Dispatch, $\quad$ Feb. $11, \quad 2015, \quad$ available http://buckeyextra.dispatch.com/content/stories/2015/02/11/buckeyes-kasich.html.

${ }^{433}$ Cindy D. Kam \& Robert A. Mikos, Do Citizens Care about Federalism? An Experimental Test, 4 J. Emp. Leg. Stud. 589, 598 (2007) (reporting results from the 2000 Attitudes Toward Government Study, but concluding that "[t]hese findings are consistent with those reported by other scholars, using other nationally representative surveys"); see also PewResearch, Center for the People \& the Press, State Governments Viewed Favorably as Federal Rating Hits New Low, April 15, 2013, available at http://www.people-press.org/2013/04/15/state-govermnents-viewedfavorably-as-federal-rating-hits-new-low/. Interestingly, levels of trust in the federal government themselves vary significantly from state to state. See Paul Brace \& Martin Johnson, Does Familiarity Breed Contempt? Examining the Correlates of State-Level Confidence in the Federal Government, in COHEN, supra note 291, at 19.

${ }^{434}$ Megan Mullin, Federalism, in NAthaniel Persily, Jack Citrin, \& Patrick J. Egan, EdS., PUblic Opinion AND CONSTITUTIONAL CONTROVERSY 216 (2008). 
others, such as government welfare programs. ${ }^{435}$ And Francis Fukuyama has argued that social trust is central to individuals' willingness to act communally in large institutions. ${ }^{436}$ It would seem to follow that, if present trends continue, we should expect people to be more willing to build institutions and support shared sacrifice at the state level than at the national one.

Whether or not we can infer self-identification with a state from the public's greater trust in state institutions, these aspects of public opinion may be important to debates about federalism in a variety of more direct ways. As Professors Kam and Mikos note, "[t]rust in government is politically consequential: it affects public opinion and voting decisions." 437 Most obviously, support for state institutions may translate into political opposition to measures that would increase federal power vis-à-vis the states. In Federalist 17, Alexander Hamilton suggested that state governments "will generally possess the confidence and good will of the people; and with so important a support will be able effectually to oppose all incroachments of the national government." ${ }^{\text {438 }}$ Robert Mikos has dubbed this phenomenon the "populist safeguards of federalism." 439 While it is difficult to establish the influence of such safeguards directly, some scholars have suggested that they were powerful enough to impel movements in the 1980s and 1990s to devolve governmental authority to the states. ${ }^{440}$ Relatedly, experience with state legalization of marijuana suggests that declining trust may lessen the normative force of federal law, especially where state law takes an opposite position. ${ }^{441}$

${ }^{435}$ See Marc J. Hetherington, Why Trust Matters: Declining Political Trust and the DEMise OF AMERICAN LIBERALISM 139 (2005).

${ }^{436}$ See Francis Fukuyama, Trust: The Social Virtues and the Creation of Prosperity (1995).

${ }^{437}$ Kam \& Mikos, supra note 433, at 599.

${ }^{438}$ The Federalist No. 17 (Alexander Hamilton), at 109 (J.E. Cooke ed. 1961).

${ }^{439}$ Robert Mikos, The Populist Safeguards of Federalism, 68 Oніо ST. L. J. 1669 (2007).

${ }^{440}$ See Marc J. Hetherington \& John D. Nugent, Explaining Public Support for Devolution: The Role of Political Trust, in What is it ABout Government that AMERICANS Dislike? 134, 134 35 (John R. Hibbing \& Elizabeth Theiss-Morse eds., 2001).

${ }^{441}$ See Robert A. Mikos, On the Limits of Supremacy: Medical Marijuana and the States' Overlooked Power to Legalize Federal Crime, 62 VAND. L. REV. 1421 (2009). 
The relative trust advantage enjoyed by state and local governments may cut against national action even when the proposed national action would further popular policies. Cindy Kam and Robert Mikos have demonstrated, based on their own surveys, that "even if Congress promises citizens the policy outcome the majority prefers-a ban on physician-assisted suicide - citizens may still doubt that the federal government will execute or interpret that policy competently, faithfully, or in accordance with their wishes." ${ }^{442}$ These sorts of doubt may become politically consequential.

Support for state autonomy may also give the Supreme Court more latitude to limit national power-should it be so inclined. Despite the firestorm of academic criticism engendered by the Rehnquist Court's "federalist revival," the Court's efforts in the 1990s and early 2000s to limit national power encountered little opposition from the national political branches and was largely consistent with public opinion on federalism. It seems unlikely that the Rehnquist revival was a response to public opinion favoring state institutions over national ones; after all, those opinions appear to be relatively weakly held, and the Court does not seem to have aroused public opposition on account of its stance favoring national power between 1937 and $1995 .{ }^{443}$ But public attitudes would seem to alleviate concerns voiced by some commentators as to whether the Court has the "political capital" to limit national power. ${ }^{444}$ As Megan Mullin concludes, if the Court "attempts to continue the legacy of the federalism revolution, its actions would probably receive the quiet consent of a public that supports the states."

Although these public attitudes do not directly prove the existence of strong state identities, they do undermine the One Nation hypothesis. After all, that theory holds that

\footnotetext{
${ }^{442}$ Kam \& Mikos, supra note 433, at 597-98.

443 See, e.g., Barry Friedman, The Will of the People: How Public Opinion Has INFLUENCED THE SUPREME COURT AND SHAPED THE MEANING OF THE CONSTITUTION (2009).

${ }^{444}$ See, e.g., Jesse H. Choper, Judicial Review and the National political Process: A FunCtional RECONSIDERATION OF THE Role OF tHe SupREME COURT 139 (1980) (suggesting that the Court should decline to enforce constitutional limits on national power in order to conserve its political capital for individual rights cases); Jenna Bednar \& William N. Eskridge, Jr., Steadying the Court's "Unsteady Path": A Theory of Judicial Enforcement of Federalism, 68 S. CAL. L. REv. 1447, 1481 (1995) (arguing that "the Court assumes institutional risks when it invalidates congressional enactments" and that "the Court is not likely to challenge national political equilibria very often").

${ }^{445}$ Mullin, supra note 434, at 229.
} 
absent strong state identities, individual citizens have no reason to-and do not-care about their states. If they nonetheless favor state institutions over national ones in important respects, something is wrong with the theory. Either its empirical assumptions are incorrect, or people may have some reason to care about states even absent strong identities.

\section{Personal Mobility}

Ha Jin, who won the National Book Award in 1999 for Waiting, says that "I don't have a hometown. I grew up a People's Liberation Army brat, moving around with my father. I can say I'm a northerner, since my first twenty-six years were spent in the northeast of China, but that is the most I can associate myself with a place." ${ }^{446}$ The editors of State by State nonetheless chose Professor Jin to write the entry for Georgia, where he taught at Emory University for a decade and lived outside of Atlanta. It was, he reports, "the first real home I had ever had." ${ }^{447}$ Jin's story highlights the complex relationship between mobility and identity. We live in a mobile society; Americans are constantly arriving from somewhere else and then, as Stephen Vincent Benét said, "always moving on." "448 (Jin left Atlanta for Boston in 2002.) ${ }^{449}$

Historically, Americans have been known for a high degree of personal mobility. ${ }^{450}$ Gordon Wood observes that Americans developed a reputation for mobility "as early as 1800," and that "no other culture has ever had so much movement as ours." 451 In the early Republic, this striking mobility did not simply undermine individuals' sense of communal attachment; it tended to undermine the development of civic community and institutions at all in the new communities springing up across the frontier. ${ }^{452}$ Likewise, contemporary observers tend to assume that incessant movement erodes strong state identities. Based on Americans" "consistently high level of geographical mobility," for example, Samuel Huntington concluded that "[i]ndividual

${ }^{446}$ Ha Jin, Georgia, in STATE BY STATE, supra note 3, at 104, 104.

${ }^{447}$ Id. at 105.

448 STEPHEN Vincent BenÉt, Western StAR 3 (1943).

449 See Jin, supra note 446, at 110.

${ }^{450}$ See Huntington, supra note 64 , at 50;

451 [find cite-quoted in Huntington, at 50, no cite in the FN]

452 See Gordon S. WoOd, THE RAdiCALISM OF THE AMERICAN REVOLUTION 309-11 (1992). 
Americans have from the first generally not developed intense attachments to particular localities." 453

Americans from Robert E. Lee to Wendell Berry might attest that Professor Huntington's conclusion is a little too quick. ${ }^{454}$ One of the best indicators of a particularly strong sense of state identity would be whether a state's one-time citizens continue to identify with the state even after work, schooling, or relationships have taken them elsewhere. ${ }^{455}$ Or all this moving about may enhance individuals' need to put down roots. Wilfred Maclay writes that "[i]n a frenetically mobile and ever more porous and inexorably globalizing world, we stand powerfully in need of . . . stable and coherent places in our lives - to ground us and orient us, and mark off a finite arena, rich with memory, for our activity as parents and children, as friends and neighbors, and as free and productive citizens." had eluded him for twenty-six years in China. One cannot simply infer, as Huntington does, a lack of attachments from the numbers of people moving each year.

Those numbers, in any event, actually undermine widespread assumptions about geographic mobility. It is widely believed that "the United States is an increasingly mobile society,"

${ }^{453}$ Huntington, supra note 64, at 50; but see Robert H. WieBe, THE SEARCh FOR ORDER 18771920, at xiii (1967) (observing that "America during the nineteenth century was a society of island communities," with relatively little communication and a focus on local life). As is common, Professor Huntington infers the lack of attachment from the mobility numbers themselves, without survey data or other empirical evidence going directly to the question of local identification. See, also Kahn, State Constitutionalism, supra note 177, at 1150 ("[I]ndividuals in the United States are extremely mobile. As individuals lose a geographical focus in their lives, they inevitably turn to the national government as the primary focus of public life.") (citing as authority a statement from the Federalist Papers that does not mention mobility).

${ }^{454}$ See, e.g., Wendell Berry, A Place ON EARTh (rev. ed. 1983) (1967).

${ }^{455}$ To pick a totally random example, say, an expat Texan law professor living in North Carolina.

${ }^{456}$ Wilfred M. McClay, Introduction, in Why Place Matters: GeOGRAPHy, IDENTITY, AND Civic Life In Modern America 1, 3 (Wilfred M. McClay \& Ted V. McAllister eds. 2014).

${ }^{457}$ Douglas A. Wolf \& Charles F. Longino, Jr., Our "Increasingly Mobile Society”? The Curious Persistence of a False Belief, 45 The Gerontologist No. 1, at 5 (2005) (noting that "a search of the World Wide Web for instances of the phrase 'our [or an] increasingly mobile society' produces well over 1,000 'hits'”). 
of the twentieth century, "short-distance mobility rates have declined substantially, whereas long-distance moves have declined less sharply or have even remained relatively unchanged." ${ }^{458}$ Similarly, Alison Stein Wellner has pointed out that "a person born today is more likely to remain near his birthplace than a person born in the $19^{\text {th }}$ century." 459 Current mobility rates are among the lowest levels recorded in the last sixty years. ${ }^{460}$ None of this is to deny that actual numbers of moves are still quite high. ${ }^{461}$ But the idea that mobility is increasing - or that it is at historically high levels today-is simply false. $^{462}$

Most Americans live in the state in which they were born. The 2010 Census found that 58.8 percent of all people in the United States were residing in their state (or district) of birth, with 27 percent born in another state and the remaining 14 percent born

${ }^{458} I d$. at 9 . More recent data suggests that interstate moves are in fact heading down. See David K. Ihrke, Carol S. Faber, \& William K. Koerber, U.S. Census Bureau, Current Population Reports, Geographic Mobility: 2008 to 2009, at 3 Table 1a (2011), available at http://www.census.gov/prod/2011pubs/p20-565.pdf [hereinafter Geographic Mobility]; see also infra note 464. Many interstate moves, moreover, may well be returns to an area of prior residence. See Julie S. DaVanzo \& Peter A. Morrison, Return and Other Sequences of Migration in the United States, 18 DEMOGRAPHY 85, 88 (1981).

459 Alison Stein Wellner, The Mobility Myth, REASON (April 2006) (available at http://reason.com/archives/2006/04/01/the-mobility-myth/1) (visited June 21, 2011).

460 See Geographic Mobility, supra note 458, at 2-3. For a discussion of how the Census Bureau assesses mobility, see Alison Fields \& Robert Kominski, America: A Nation on the Move, RANDOM SAMPLINGS, Dec. 10, 2012, http://blogs.census.gov/2012/12/10/america-a-nation-on-themove/.

${ }^{461}$ See Fields \& Kominski, supra note 460.

462 See Harry Enten \& Nate Silver, Migration Isn't Turning Red States Blue, FiveThiRTYEIGHTPOLITICS, Aug. 29, 2014, available at http://fivethirtyeight.com/features/migration-isnt-turning-red-states-blue/ ("Interstate migration is not increasing. Instead, it has been on a downward trend since the 1980s; fewer Americans (as a share of the population) are relocating across state lines than a couple of decades ago."). The persistence of the myth may reflect the atypical life experiences of academics. See Wolf \& Longino, supra note 457, at 10 (noting that "[f]alse claims about trends in mobility made by academics or other professionals might reflect excessive reliance on personal experience or observation," and that "[l]ong-distance career-related moves are commonplace among academic scholars, who tend to operate in a national job market"). 
abroad or in a U.S. territory. ${ }^{463}$ A 2013 study by the Federal Reserve Bank of Minneapolis found that interstate moves had fallen by fifty percent since the early $1990 \mathrm{~s}$ - from 3 percent of persons to 1.5 percent. ${ }^{464}$ The authors offered two theories to account for this decline: First, "labor markets around the country have become more similar in the returns they offer to particular skills, so workers need not move to a particular place to maximize the return on their idiosyncratic abilities." ${ }^{.465}$ And second, "better information - due to both information technology and falling travel costs- has made locations less of an experience good, reducing the need for young people to experiment with living in different places." 466 Anyone who's watched House Hunters on HGTV - and who hasn't? - ought to have some idea what they'd be getting into if they moved to most metropolitan areas of the U.S. or Canada. ${ }^{467}$

All interstate moves are not the same. Two variables may help us begin to assess the impact of mobility on geographically-specific identities. The first is the scale of the movement. If people move as isolated individuals, they may well lose touch with old

${ }^{463}$ Ping Ren, U.S. Census Bureau, American Community Survey Briefs, Lifetime Mobility in the United States: 2010, at 1 (2011), available at http://www.census.gov/prod/2011pubs/acsbr1007.pdf. Interestingly, the states vary rather widely on this point: 78.8 percent of persons living in Louisiana in 2010 were born there, for example, while only 24.3 percent of Nevada residents were born in that state. $I d$. Likewise a recent Gallup poll found only 23 percent of people in Montana, Hawaii, and Maine expressing a desire to leave, while roughly half the populations of Illinois and Connecticut "want to get the hell out." Danielle Kurtzleben, Half of People Living in Illinois and Connecticut Want to Get the Hell Out, Vox, April 30, 2014, available at http://www.vox.com/2014/4/30/5668588/illinois-connecticut-maryland-gallup-interstate-

migration-rates. Gallup noted a correlation between the states most at risk of losing population and those states in which residents express low levels of satisfaction with state taxes and state government. See Lydia Saad, Half in Illinois and Connecticut Want to Move Elsewhere, GaLluP, April 30, 2014, available at http://www.gallup.com/poll/168770/half-illinois-connecticut-moveelsewhere.aspx.

${ }^{464}$ Greg Kaplan \& Sam Schulhofer-Wohl, Understanding the Long-Run Decline in Interstate Migration, Working Paper 697 (Dec. 2013), available at https://www.minneapolisfed.org/research/wp/wp697.pdf.

${ }^{465} I d$. at 2.

${ }^{466} \mathrm{Id}$.

${ }^{467}$ See House Hunters, HGTV, http://www.hgtv.com/shows/house-hunters (visited Feb. 22, 2015). 
attachments and struggle to build new ones. ${ }^{468}$ But when people migrate in groups over a sustained period to particular destinations, they may profoundly shape the character of the destination community and render it more distinctive. A significant literature documents the profound effect of migration patterns - both from abroad and internal to the United States - in determining the political culture of particular American regions. ${ }^{469}$ And much of what makes Texas distinctive-from the food and the elegant place names to the unique three-cornered racial politics - arises from its Hispanic heritage and migration. ${ }^{470}$ Migrations, in other words, may help foster the sense that a given state, unlike Gertrude Stein's Oakland, has a "there" there. ${ }^{471}$

A second variable is the reason for movement. We might distinguish between "uprooting," that is, moving to follow a job or a spouse, without any general sense of affinity for the new locale, and "sorting," or moving to a place where one expects to feel more at home. Much uprooting in this country has occured in response to broad historical forces - the Civil War, the African-American diaspora after the abolition of slavery, the Great Depression, World War II-that either coerce people to move or simply make conditions intolerable in their original homes. ${ }^{472}$ One would expect this sort of mobility to undermine state identity and, in some cases, to encourage people to develop a national outlook. As Aaron Wildavsky pointed out, "[a] person living in the same town or neighborhood most of his life . . might be motivated to climb the party ladder to a

${ }^{468}$ Forces of technology and globalization-which are usually thought to undermine local attachments - may actually make those attachments easier to maintain at a distance. See, e.g., The County Line, http://www.airribs.com/ (visited Feb. 8, 2015) (mail order site for the County Line Bar-B-Q in Austin, Texas); Perini Ranch, Online Store, http://store.periniranch.com/products/ (visited Feb.8, 2015) (mail order site for the Perini Ranch Steakhouse in Buffalo Gap, Texas).

${ }^{469}$ See, e.g., BARONE, supra note 48; FISCHER, supra note 63; WOODARD, supra note 294; ELAZAR, MOSAIC, supra note 63.

${ }^{470}$ See THORBURN, supra note 302, at 14 ("Much of the culture of Texas developed from the state's association with Mexico, whether in fine arts or in popular culture and folkways, an association that provides a continuing contribution to what Texas is today.").

${ }^{471}$ Stein's statement is generally misinterpreted. As Professor McClay explains, she was actually lamenting the disappearance of the strong sense of place that she had felt as a child growing up in Oakland - not trying to put down the city. McClay, supra note 456, at 1-2.

${ }^{472}$ See, e.g., JOHN STEINBECK, THE GRAPES OF WrATH (1939) (chronicling the Joad family's migration from Oklahoma to California in the wake of the Dust Bowl). 
position of prominence. The same person who keeps changing residence . . might be better off attaching herself to a national interest group, available whenever she wants and willing to recognize prior participation no matter where it occurred." ${ }^{, 473}$ More generally, Albert Hirschman argued that "loyalty" was the critical factor that encourages individuals to exercise voice rather than exit when they become dissatisfied with some aspect of a current organization or community. ${ }^{474}$ If there is lots of exit, we might infer low levels of loyalty. ${ }^{475}$

By the second half of the twentieth century, large-scale moves in response to social forces were giving way to what Michael Barone calls "migrations of choice."476 These moves involve sorting rather than uprooting. If people move freely to the state most congenial to them, they might well form stronger attachments to that state than to the one they were randomly born into. People appear to sort both because of the lifestyle that a "red" or "blue" community signifies, but also as a deliberate choice to live among politically-likeminded people. ${ }^{477}$ "Americans have tended to move to neighborhoods and to states and metropolitan areas where their own political views are dominant," Mr. Barone observes. ${ }^{478}$ "Young professionals who can choose where they will live gravitate toward the San Francisco Bay Area and like-minded places if their values and views are

${ }^{473}$ WILDAVSKY, supra note 1 , at 4 . To the extent that traditional decentralized political parties have been a critical component of American federalism, see, e.g., Kramer, supra note at this dynamic would threaten a key element of the federal order.

${ }^{474}$ HiRschman, supra note 21 , at _. On the other hand, a person who felt alienated in her home state may be more inclined to exercise voice in a new state of residence where her views are more in tune with the community's norms.

${ }^{475}$ Professor Hirschman spoke of exit as an alternative to voice. HIRSCHMAN, supra note 21, at _. Exit ends the possibility of voice in the home jurisdiction, but Hirschman's focus on that jurisdiction submerged another possibility, which is that relocation may enhance one's opportunity for voice in the new place.

${ }^{476}$ BARONE, supra note 48 , at 227.

${ }^{477}$ Elving, supra note 383 ("We thought at first that this was all lifestyle, but the more I talked to people, the more I talked to people who said it was a conscious decision to go to a Democratic area or a Republican area.") (quoting Bill Bishop); see also BARONE, supra note 48, at 232 ("[V]olitional migration ... consists primarily of movement from high-tax states to low-tax states but also of movements to culturally congenial communities.").

${ }^{478}$ BARONE, supra note 48 , at 266. 
liberal, and toward the Dallas-Fort Worth Metroplex and other like-minded places if their values and views are conservative." 479

We thus have reason to believe that the general decline in mobility might decrease the sorts of movement that undermine personal identification with one's state (uprooting), while at the same time those moves that do happen may be more likely to enhance the movers' sense of personal fit with their communities (sorting). Some empirical evidence seems to support this hypothesis. Although some observers have suggested that the "Blue State Diaspora"- the widespread tendency of people to move from blue to red states - will turn the latter states "purple," suggests that this is a mirage. Analyzing General Social Survey data, which tracks both political beliefs and duration of residence in particular states, Harry Enten and Nate Silver found that "[i]f anything, movers generally have more extreme political views than natives: Those people moving to the West Coast or New England, for example, are more liberal than people who grew up there." ${ }^{, 41}$ They concluded that "the people moving away from a region are ideologically distinct from those who continue to live there," with the result that "migrants' political beliefs mirror those of voters in their new destination.",482

If this is right, then sorting likely prevails over uprooting in the contemporary era. Rather than undermining one's comfort level in one's state of residence, mobility may well enhance it. As Ha Jin's story illustrates, sometimes moving is more like coming home.

At the end of the day, the empirical question that this essay set out to address may remain at least somewhat intractable. Notwithstanding extensive empirical work supporting the existence of distinctive state political cultures, one cannot conclusively demonstrate that state political culture or identity exist or pin down the degree to which they may have declined since the origins of our nation. That difficulty also attaches, of

${ }^{479} I d$.

${ }^{480}$ See Robert Gebeloff \& David Leonhardt, The Growing Blue-State Diaspora, N.Y. TIMES, Aug. 23, 2014, available at http://www.nytimes.com/2014/08/24/upshot/the-growing-blue-statediaspora.html.

${ }^{481}$ Enten \& Silver, supra note 462.

${ }^{482}$ Id. 
course, to any assertion that state identity does not exist, and part of my point is simply to insist that such assertions cannot be established as fact simply by the impressions of law professors whose experiences may be far from typical. For every colleague I have encountered who is surprised that anyone would care about their state, I have also encountered someone (often a student) equally surprised anyone would doubt that such attachments exist. I do think that the evidence canvassed here tends to confirm Matt Weiland's more impressionistic assessment:

The fifty states themselves have individual places in our collective imagination, and they offer their natives a mind-set, even a world-view. For all the talk of identity in American life, the personal fact that defines American lives as much as gender, ethnicity, or class is where you're from, which more than anything means your home state. ${ }^{483}$

\section{Other Levels of Attachment: Of Cities and Regions}

Even if one accepts that Americans often have strong identities that are more particularistic than their allegiance to the nation, one might sensibly ask whether those identities are most likely to be grounded in states, as opposed to some other geographical unit. When Frank Sinatra recorded "New York, New York," he was not singing about New York state. ${ }^{484}$ A number of scholars have argued that, in contemporary society, the states are simply too large to be meaningful sites of democratic activity, and that the values of popular participation and democratic accountability traditionally associated with states are more likely to be realized at the local level. ${ }^{485}$ And recent demographic research has suggested that the most important political and cultural diversity exists within states rather than among them. ${ }^{486}$

\footnotetext{
${ }^{483}$ Matt Weiland, Preface, in State By State, supra note 3, at xiv.

${ }^{484}$ Interestingly, when the editors of The Nation commissioned their essay series on each American state in the 1920s, they included separate entries for New York City and New York state. See TheSe United StATES 1920s, supra note 58, at 2 n.1 (noting that "the editors thought the metropolis had little intrinsic relationship with New York State and hence deserved an article of its own.").

${ }^{485}$ [cites]

${ }^{486}$ See, e.g., Bill Bishop, The Big Sort: Why the Clustering OF Like-Minded AMERICA IS TEARING Us APART (2008). Indeed, Bishop's work suggests that cities may be too large as units and that much identity-based sorting is occurring at the neighborhood level. See id. at
} 
Conversely, we might argue that identity more likely reposes at the regional level. Many residents of the states of the old Confederacy may well identify more strongly as "southerners" than as citizens of Missisippi, Georgia, or North Carolina. Most of the existing literature on distinctive political subcultures within the United States focuses on the regional level. ${ }^{487}$ Regional affiliation might be expected to trump state identity particularly in areas like New England, made up of small states that collectively remain smaller than behemoth jurisdictions like California or Texas. And to the extent that state identities are forged through historical instances of action against the tide of national politics, those instances tend to involve states acting collectively in regional groups. The Confederacy is obviously the most salient example, but others include the Midwestern progressives in the late nineteenth century or the New England states that nearly seceded over the trade policies of the Madison administration. ${ }^{488}$

These are all plausible arguments, and I do not undertake to prove here that states are always or necessarily more important to people than their cities or regions. Instead, I offer three more modest points. First, a considerable measure of distinctiveness and identity exists at the state level, independent of local or regional affiliations. Second, there is little reason to think that, in most cases, these other affiliations undermine or trade off with state identity. And third, the states provide the most important institutional locus of policymaking and identity in our federal system, and for that reason state distinctiveness and identity is of primary concern.

\section{A. American City-States and the "Big Sort"}

Many of the same decentralizing arguments for federalism can be made for devolving political authority even further to cities and counties. ${ }^{489}$ And for many contemporary Americans, cities seem to form a more central aspect of identity than states. Professional sports franchises, for example, tend to be identified with particular

487 See, e.g., Nicole Mellow, The State of Disunion: Regional Sources of Modern AMERICAN PARTisAnShiP (2008); W.J. CASH, THE Mind OF THE SOUTH (1941).

${ }^{488}$ See, e.g., James M. Banner, To the Hartford Convention: The Federalists and the ORIGINS OF PARTY POLITICS IN MASSACHUSETTS, 1789-1815 (1970).

${ }^{489}$ See, e.g., Gerken, All the Way Down, supra note 7, at _; see also Levy, supra note 23, at 461 (observing that "the states and provinces that make up really existing federalism are, in general, too large" for "competitive federalism or ... Tiebout sorting"). 
cities, rather than states. ${ }^{490}$ In politics, Bill Bishop has prominently argued for a "Big Sort" in which Americans are self-segregating politically into ideologically homogenous local units. ${ }^{491} \mathrm{Mr}$. Bishop suggests that the commonly debated phenomenon of "red" and "blue" states is not nearly so important as the category of "landslide counties-counties where one party won [a competitive presidential election] by 20 percentage points or more." "B92 "Beginning in 1992," Bishop observes, "the percentage of people living in landslide counties began an upward, stairstep progression. And by 2004 in one of the closest presidential contests in history, 48.3 percent of voters lived in communities where the election wasn't close at all. ${ }^{, 493}$ Bishop concludes that "people don't live in states. They live in communities. And those communities are not close to being in equipoise, even within solidly blue or red states. ... As Americans have moved over the past three decades, they have clustered in communities of sameness, among people with similar ways of life, beliefs, and, in the end, politics." 494

The tension between local and state governments is a fixture of contemporary federalism debates. ${ }^{495}$ It is not my topic to assess that tension here. The question, rather, is whether local identities have replaced, or can replace, state political identity as the relevant units of American federalism. Well-developed institutions do exist at the local level, but they suffer certain disadvantages as a locus for identity and political

\footnotetext{
${ }^{490}$ Only five out of thirty-two National Football League franchises, for example, are named after their home states. (One of them, the Charlotte-based Carolina Panthers, tries to have it both ways as between North and South Carolina, and the Houston Texans invoke both city and state.) The New England Patriots are named after a region. Originally named the Boston Patriots, the franchise strongly considered "the Bay State Patriots" after a nickname for the Commonwealth of Massachusetts. This was apparently dropped for fear of being branded "the B.S. Patriots." See Martin Rogers, Why Are They Called the New England Patriots?, ThePostGame, Yahoo! Sports, Feb. 1, 2012, available at http://www.thepostgame.com/blog/throwback/201202/true-patriots-lovehow-new-englands-nfl-team-got-its-name.

${ }^{491}$ Bill Bishop, The Big Sort: Why the Clustering of LiKe-Minded AMERICA Is TeAring Us APART (2008).

${ }^{492}$ Id. at 9 . See also id. at 44 ("California is the stereotypical 'blue' state. But within California, 17 counties grew more Democratic after 1976, and 30 became more reliably Republican.”).

${ }^{493} I d$. at 11 .

${ }^{494} I d$. at 5 .

${ }^{495}$ See, e.g., David Barron, A Localist Critique of the New Federalism, 51 DukE L. J. 377 (2001).
} 
community. One problem is that local governing jurisdictions often fail to track the boundaries of imagined communities at the local level. ${ }^{496}$ To the extent that "Boston" is a political community, it surely contains close-in cities like Chelsea, Everett, and Revere, and arguably Brookline, Cambridge, and other jurisdictions as well. ${ }^{497}$ But there is no single self-governing set of institutions corresponding to this broader local community, and in fact many might well disagree not only as to its actual boundaries but also as to who counts as a member of the community. ${ }^{498}$ The result, as Anthony Smith notes, is that

${ }^{496}$ Likewise, federal OMB guidelines for defining metropolitan areas take account of local opinion - that is, what community residents think they are a part of - only in marginal cases. See OMB's Standards for Defining Metropolitan Statistical Areas (summarizing Dec. 27, 2000 notice in Federal Register), available at http://cber.cba.ua.edu/rbriefs/news010501.html.

${ }^{497}$ See U.S. Census Bureau, Geographic Areas Reference Manual, at 13-3 ("[I]t must be considered that the neighboring towns of Quincy, Dorchester, Milton, Roxbury, Brookline, Brighton, Watertown, Cambridge, Charlestown, Medford, Malden, and Chelsea, although not included in the [Boston] city charter, are component parts of the city, and are . . associated with it in all its commercial, manufacturing, literary, and social relations and feelings ....") (quoting Boston's 1846 entry in The New England Gazetteer); see also Wendell Cox, Large Urban Cores: Products of History, NEWGEOGRAPHY, July 17, 2014, available at http://www.newgeography.com/content/004428-large-urban-cores-products-history (identifying Boston and New York as "metropolitan areas where the urban core stretches well beyond the core municipality's city limits"). For a sense of the complexities, see Greater Boston, WIKIPEDIA, http://en.wikipedia.org/wiki/Greater_Boston (visited Dec. 7, 2012) ("Due to ambiguity in usage, the size of the area referred to can be anywhere between that of the metropolitan statistical area (MSA) of Boston and that of the city's combined statistical area (CSA), which includes the metro areas of Providence, Rhode Island and Worcester, Massachusetts."); see also Metropolitan Area Planning Council, The MAPC Region and Its Subregions, available at http://metrobostondatacommon.org/site_media/calendar/Calendar2010_00_region.pdf (visited Dec. 7, 2012) (providing a map of what Wikipedia describes as " $[t]$ he most restrictive definition of the Greater Boston area").

${ }^{498}$ Cf. Daniel K. Wallingford, Bostonian's Idea of the United States of America, map c. 1930s-40s, available at http://www.georgeglazer.com/archives/maps/archive-newengland/bostonian.html (visited Dec. 7, 2012) (commenting that "[a] person born in the city of BOSTON and residing in BOSTON may not be a BOSTONIAN; yet a person born in Hingham, residing in Newton [and making] frequent crossings to England and the Continent . . . is likely to be a BOSTONIAN," and complaining that "[t]he lack of a definite text-boook definition for A BOSTONIAN has added to the many difficulties encountered by the Publishers of this map"). 
"localities may easily disintegrate into separate settlements." the phenomenon Bill Bishop documents: "The Big Sort" is not primarily into like-minded cities, but rather into even small enclaves of homogeneity within cities. As Bishop explains, “[w]hen my wife and I moved to Austin, we didn't go hunting for the most Democratic neighborhood in town. But the result was the same: moving to Travis Heights, we took a side and fell into a stark geographic pattern of political belief, one that has grown more distinct in presidential elections since 1976. ${ }^{, 500}$

The second problem with localities as a locus for political identity is that local governments generally lack federal constitutional recognition or protection. Vigorous debate exists as to whether federalism is good for local autonomy. ${ }^{501}$ However, if we are ultimately concerned about federalism for other reasons - such as its role in checking the power of national institutions ${ }^{502}$ - then it seems unlikely that local institutions are likely to be of much help. The institutional autonomy of local governments may well have peaked in the nineteenth century. Both trends in the development of cities and pressures deriving from federal programs have undermined the institutional autonomy and capacity of local government. ${ }^{503}$

Finally, the overwhelming majority of Americans live in a state, ${ }^{504}$ but a relatively small percentage live in a city like New York. How many localities can truly claim a local identity trumping their states? Urban geographers have recognized that "the "urbaneness' of central cities var[ies] greatly." ${ }^{, 505}$ Cities vary widely in the density of the

\footnotetext{
${ }^{499}$ SMITH, supra note 94 , at 4.

${ }^{500}$ BISHOP, supra note 486 , at 5 .

501 [cites]

${ }^{502}$ See infra Part III.

${ }^{503}$ See Martha Derthick, How Many Communities? The Evolution of American Federalism, in Dilemmas of Scale in America's Federal Democracy 125, 127-42 (Martha Derthick, ed., 1999) [hereinafter DILEMMAS OF SCALE].

${ }^{504}$ And some of those that don't, such as Puerto Ricans, live in communities that effectively function as states for most purposes in our system. See, e.g., Calero-Toledo v. Pearson Yacht Leasing Co., 416 U.S. 663, 672 (1974) ("'Puerto Rico has . . . not become a State in the federal Union like the 48 States, but it would seem to have become a State within a common and accepted meaning of the word.'”) (quoting Mora v. Mejias, 206 F.2d 377, 387 (1st Cir. 1953)).

${ }^{505}$ Cox, Urban Cores, supra note 497.
} 
population within the core city's jurisdiction and the proportion of the metropolitan area that the core city comprises. ${ }^{506}$ Besides the Big Apple, one might make a case for Los Angeles, Chicago, Boston, and perhaps San Francisco; alternatively, one might emphasize metropolitan areas that are not cities but perhaps claim a distinctive identity, such as Orange County or Silicon Valley. But while the Census Bureau defines "urban" as any area with 50,000 or more people, it seems highly doubtful that denizens of smaller cities like Wichita, Kansas (population 386,000$)^{507}$ or Abilene, Texas (population $120,000)^{508}$ think of themselves as distinct from other Kansans or Texans, respectively. A world in which cities were the primary locus of identity would thus leave out not only the 16 percent of Americans who live in rural areas, ${ }^{509}$ but also the overwhelming majority of urbanites as well. It seems more sensible to think of certain cases like New York Citywhose population in 2010 would have ranked between Virginia (12th) and Washington (13th) if it were a state ${ }^{510}$ - as comparable to states for many purposes.

\section{B. Regionalism in the American Federal System}

For much of our history, American politics have been dominated not by individual localities or states but rather by sectionalism - that is, the politics and rivalries of larger regions. ${ }^{511}$ Part of the significance of regions is economic. As Nicole Mellow notes, "despite nationwide industrial and post-industrial development in the last halfcentury, American regional economies still differ and translate into divergent policy preferences." 512 More broadly, however, she argues that "regional culture" embodies a "web of meanings, symbols, foundational principles, and interpretive frameworks that have broad political effects independent of any given [demographic] group or population. ${ }^{, 513}$ In this vein, C. Vann Woodward famously argued that the South as a

\footnotetext{
${ }^{506}$ See id.

${ }^{507}$ See http://en.wikipedia.org/wiki/Wichita, Kansas (visited Feb. 24, 2015).

${ }^{508}$ See http://en.wikipedia.org/wiki/Abilene,_Texas (visited Feb. 24, 2015).

509 [2010 census figures]

${ }^{510}$ [2010 census figures]

511 See, e.g., Frederick Jackson Turner, The Significance of Sections in American HISTORY (1932).

${ }^{512}$ Mellow, supra note 487, at 17.

${ }^{513} I d$. at 18 .
} 
region had important contributions to offer American culture and politics, ${ }^{514}$ and Daniel Elazar's political cultures were at least partially regional phenomena, not limited to particular states. $^{515}$

I do not mean to deny the significance of regional distinctiveness or identity here. I doubt, however, that regions can play the same role as states in the maintenance of American federalism. One problem is that "regions are geographically difficult to define; their centres are often multiple and their boundaries ragged." 516 To the extent that American law divides the country regionally, it tends to draw different groupings for different purposes. The General Services Administration's "Region 1," for instance, includes Maine, New Hampshire, Vermont, Massachusetts, Rhode Island, and Connecticut. ${ }^{517}$ But the United States Court of Appeals for the First Circuit has jurisdiction only over Maine, New Hampshire, Massachusetts, and Rhode Island-and Puerto Rico, of course. ${ }^{518}$ Although these demarcations have considerable bureaucratic and legal significance, one suspects that their cultural salience is approximately zero. Hence, Nicole Mellow argues that "[f]or understanding politics, ... [w] hat distends or contracts a region's boundaries is the number of shared experiences among its inhabitants, given the political issues and events of the moment." ${ }^{\text {,519 }}$ From the standpoint of shared experience, the more important boundary of New England, culturally speaking,

\footnotetext{
${ }^{514}$ See WOODWARD, supra note 186, at 25.

515 See ElAZAR, Mosaic, supra note 63, at _.. For other regional theories, see, e.g., FisCHER, supra note 63; Colin WoOdard, American Nations: A History of the EleVen Rival Regional Cultures of North America (2011); Joel Garreau, The Nine Nations of North AMERICA (1981).

${ }^{516}$ SMITH, supra note 94, at 4; see also Mellow, supra note 487, at 23 ("[R]egions should be thought of as to some extent mutable or as having 'variable edges."').

517 See General Services Administration, New England: About Region 1, available at http://www.gsa.gov/portal/category/21432 (visited Dec. 20, 2012).

518 See United States Courts, Court Locator, available at http://www.uscourts.gov/court locator.aspx (visited Dec. 20, 2012).

${ }^{519}$ MeLLOW, supra note 487, at 23.
} 
may be that tipping point somewhere in the middle of Connecticut where baseball fans of the New York Yankees start to outnumber Boston Red Sox fans. ${ }^{520}$

A further complication arises from the tendency of many geographers to define regions as a central large city and its surrounding hinterland. ${ }^{521}$ More recently, some geographers and planners have advanced a similar regional geography based on "megapolitans," defined as "regions that encompass cities and counties linked through man-made and natural connections such as shared transportation networks, labor markets or water supplies. ${ }^{, 522}$ But however compelling the case - particularly economic-may be for planning around these sorts of regions, they are considerably smaller than the regions that dominate popular consciousness. Faulkner's account of a Southern boy dreaming of refighting the "Lost Cause," ${ }^{523}$ for example, cannot be confined to the Atlanta megapolitan area; it defines a much broader region consisting of all the states of the Old Confederacy. When Americans think of "the South," or "the Midwest," or "the West Coast," they are generally envisioning a different and broader set of regions than professional planners often do. ${ }^{524}$

${ }^{520}$ For a relatively sophisticated attempt to trace this boundary, see John Branch, Where Do Rivals
Draw the Line?, N.Y. TIMES, Aug. 18, 2006, available at http://www.nytimes.com/2006/08/18/sports/baseball/18fans.html?pagewanted=all\&_r=0.

Interestingly, once one leaves the battleground state of Connecticut, "the swerves of the baseball boundary harden into straight lines" determined largely by state boundaries. Id.; see also id. (suggesting that "the state line [between Massachusetts and New York] seems built on baseball as much as colonial politics").

${ }^{521}$ See Green, supra note _ , at 283 ("The concept of the metropolitan community ... holds that a large city tends to organize the region surrounding it. ... The city is the focal point of regional activity, with the hinterland carrying on functions that are necessary to the metropolitan community as a whole.").

${ }^{522}$ Haya El Nasser, Megapolitan Areas Compete Globally, USATODAY, Nov. 28, 2011, available at http://usatoday30.usatoday.com/news/nation/story/2011-11-

17/megapolitan/51451598/1?csp=34news. See generally ARTHUR C. NELSON \& ROBERT E. LANG, Megapolitan America: A NeW Vision for Understanding AMERiCAN's Metropolitan GEOGRAPHY (2011).

${ }^{523}$ See supra text accompanying note 410.

${ }^{524}$ For example, consider these two efforts by young geography academics to capture the American regions in this broader sense: Andrew Shears, Regions of the Continental United States (According to . . . Me), andrewshears.com, Sept. 21, 2010, available at 
At the same time, the regions that loom large in popular consciousness may be, well, too large. Even the old South was quite diverse internally; Clement Eaton called that region "a federalism of cultures." ${ }^{, 525}$ How much more diverse is the South today, without slavery to unite it? Likewise, even the smallest region-New England-is divided between a pastoral north (New Hampshire, Vermont, and Maine) and the bustling south (Massachusetts, Connecticut, and Rhode Island). One generally does not see common institutions uniting regions on this scale, and the Constitution confers no recognition on regions at all. Indeed, the opposite is true: Article V's prohibition of depriving any state of its equal suffrage in the Senate is, in effect, a bar to folding the states into larger regional units.

Nor does evidence of the continuing political significance of regions or sections necessarily undermine the argument that I have made about state identity. First, we do have important empirical confirmation that regional identity does not capture all relevant variation in political attitudes. Even within regions, the Statehouse Democracy study found that "[k]nowing a person's state . . . does add to our ability to forecast a person's partisanship or ideology beyond what we know . . . from the person's demographics and region together." 526 If regions are politically distinctive in their own right, then, state political cultures are still more distinctive. Second, it is not necessarily the case that local or regional identity would trade-off with state identity in a negative way. As I argue in Part VI, identity may often be cumulative, so that identifying with one's family or town makes it more likely that one will also develop attachments to one's state, region, and nation. ${ }^{527}$ Certainly, the Southern region is generally taken to be the place where individuals identify most strongly with their states.

http://andrewshears.com/2010/09/21/regions-of-the-continental-united-states-according-to-me/;

Emily Fekete, Regions of the United States According to Me, Entertaining Half-thoughts, Sept. 17, 2010, available at http://emilyfekete.wordpress.com/2010/09/17/71/.

${ }^{525}$ Clement Eaton, The Mind of the Old South 24 (1964); see also Emory Thomas, The CONFEDERATE NATION: 1861-1865, at 34 (1979) ("Topographically the section varied from the swamps of Louisiana to the mountains of western Virginia; culturally Southerners included such diverse peoples as Creoes, European immigrants, mountaineers, the first families of Virginia, and Texas frontiersman.”).

${ }^{526}$ ERIKSON, WRIGHT, \& MCIVER, supra note 288, at 50-52.

${ }^{527}$ See infra text accompanying notes __- 
Finally, states remain the most important institutional players, particularly as a matter of constitutional law. America largely lacks strong regional institutions, ${ }^{528}$ apart from a few interstate compacts and coalitions devoted to particular policy issues like air pollution. To the extent that regional identities matter, then, political action based on those identities will generally have to go through the states. Scholars have recognized that the capacity for political action is itself important for identity; as David Miller points out, "[t]he fact that the community in question is either actually or potentially selfdetermining strengthens its claims on us both as a source of identity and as a source of obligation." ${ }^{529}$ Because regions - as opposed to states or provinces-typically lack an institutional framework for self-governance, they have not typically served as an effective basis for popular mobilization. According to Anthony Smith, "[o]nly rarely do we meet a powerful and cohesive regional movement, as in the Vendée during the French Revolution. . . . In most other cases 'regionalism' is unable to sustain the mobilization of its populations with their separate grievances and unique problems."

\section{Loyalty, Treason and the Paradox of Identity in a Multi-Level Polity}

Many will resist celebrating state allegiances in a time of concern about national solidarity. On the one hand, we worry about nationalism itself as a divisive force in the world. ${ }^{531}$ On the other, we also worry that our own nation is paralyzed by division and perhaps even, in Charles Murray's phrase, "coming apart" on partisan, class, or regional lines. ${ }^{532}$ My choice of Robert E. Lee to illustrate the notion of loyalty to a State, for example will inevitably summon up a host of unfavorable associations. ${ }^{533}$ Most academics I know see Lee as a traitor and a racist—not the folk hero cherished by

\footnotetext{
${ }^{528}$ See, e.g., Mellow, supra note 487, at 21 (acknowledging that "regions don't have strong institutional and constitutional forms to bind them" but must "cohere through a history of shared values and symbols as well as material realities").

${ }^{529}$ Miller, supra note 94, at 12; see also SHARANSKY, supra note 81, at 108 (“[P]articipation in collective democratic life is itself a powerful source of identity.”).

${ }^{530}$ SMITH, supra note 94 , at 4.

${ }^{531}$ See, e.g., NUSSBAUM, LOVE OF COUNTRY, supra note 5.

${ }^{532}$ See MURRAY, supra note 258; see also BISHOP, supra note 486; [others].

${ }^{533}$ See Cohen, supra note 25; see also Rubin, supra note 12, at 46 (suggesting attachment to federalism is motivated by the "sinister yearning of some Americans for the moonlight, magnolia, and mint-julep era of the antebellum South").
} 
Confederate wannabes or the brilliant general lauded by military historians. More generally, many legal scholars generally view appeals to federalism as inevitably grounded in racism or some other "sinister" motive. ${ }^{534}$

One would have hoped we would be past that by now. Lynn Baker and I argued at length a decade ago that there is no necessary connection between a commitment to the constitutional autonomy of the states and the unworthy causes of slavery and racism in which that autonomy was enlisted for much of our history. ${ }^{535}$ Most important for present purposes, issues of race in this country have been largely nationalized by constitutional amendment, ${ }^{536}$ with the result that contemporary debates about federalism generally are about same-sex marriage, clean air policy, or tort reform—not race.

This change in the issue agenda, as well as the recent period of Republican control over all three branches of the national government, has led many liberals to rethink their previously automatic equation of federalism with oppression. ${ }^{537}$ Likewise, liberals are slowly rediscovering a long history of state-based activism for progressive causes. ${ }^{538}$ It remains possible, of course, that state governments will be less progressive

\footnotetext{
${ }^{534}$ See, e.g., Seth Kreimer, Federalism and Freedom, 574 Annals AM. ACAD. Pol. \& Soc. SCI. 66, 67 (2001) ("In my formative years as a lawyer and legal scholar, during the late 1960s and 1970s, [federalism] was regularly invoked as a bulwark against federal efforts to prevent racial oppression, political persecution, and police misconduct."); Peter J. Smith, Federalism, Lochner, and the Individual Mandate, 91 B.U. L. REV. 1723, 1746-47 (2011) (comparing federalism-based arguments against the Affordable Care Act to arguments for racial segregation).

${ }^{535}$ Lynn A. Baker \& Ernest A. Young, Federalism and the Double Standard of Judicial Review, 51 Duke L. J. 75, 133-62 (2001).

${ }^{536}$ To say these problems have been nationalized is not, of course, to say they have been solved.

${ }^{537}$ See, e.g., David J. Barron, Reclaiming Federalism, DisSENT (Spring 2005). As Professor Schapiro's work demonstrates, contemporary federalism has been enlisted to support a wide variety of causes, many of them associated with political liberalism. See Robert A. Schapiro, Not Old or Borrowed: The Truly New Blue Federalism, 3 Harv. L. \& POL'y Rev. 33, 33 (2009) (hailing a "trend of state-level reform [that] represents a kind of return to the early Progressive movement . . . when state-sponsored programs constituted the core of the Progressive agenda"); see also Gerken, New Progressive Federalism, supra note 27; Kathleen M. Sullivan, From States' Rights Blues to Blue States' Rights: Federalism After the Rehnquist Court, 75 FordHam L. Rev. 799 (2006).

${ }^{538}$ See, e.g., ZACKIN, supra note 326.
} 
than national authorities on any given issue, but there is no longer reason to think that this will be true more often than not. ${ }^{539}$ In Scotland, for example, devolution and even secession are associated with progressive politics, ${ }^{540}$ and the German Constitutional Court has long resisted full integration into the EU out of concerns for protecting human rights and the institutions of social democracy. ${ }^{541}$

Colonel Lee's decision had two distinct dimensions: his choice of his state government over his national one, and his choice of the pro-slavery side over the antislavery side. ${ }^{542}$ They are separable in principle-which is not to say that either was appropriate. As an Air Force brat, raised in the Strategic Air Command during the Cold War, I have to agree that Lee was guilty of treason. My interest here is in what Daniel Elazar called a "federal political culture," $" 433$ in which individuals owe loyalty to both the nation and the state. Supporting secession out of loyalty to a state is no better than working to obliterate the states out of loyalty to the nation.

${ }^{539}$ Indeed, if feelings of social solidarity and trust are necessary to foster support for redistributive policies, see HETHERINGTON, supra note 435 , then there may be good reasons for progressives to prefer state governments.

${ }^{540}$ See, e.g., James Maxwell, Too close to call: Scottish independence vote hinges on working class, AlJAZEera AMERICA, Sept. 14, 2014, available at http://america.aljazeera.com/articles/2014/9/14/scotland-referendumanalysis.html (observing that the Scottish National Party gained traction because Scots were "frustrated with Labour's rightward drift under Tony Blair"). On this point, note also the left-wing "Second Vermont Republic," which advocates secession from the United States. See The Montpelier Manifesto, SECOND VERMONT REPUBLIC, Aug. 29, 2012, available at http://vermontrepublic.org/the-montpeliermanifesto/.

${ }^{541}$ See Brunner v. European Union Treaty, [1994] 1 C.M.L.R. 57 (1993); see generally Ernest A. Young, The European Union: A Comparative Perspective, in OXFORD HANDBOOK OF THE EUROPEAN UNION (forthcoming 2015).

${ }^{542}$ One can quibble, of course, about the extent to which the Union was anti-slavery, especially at the outset of the War. See, e.g., James M. McPherson, Battle Cry of Freedom: The Civil WAR ERA 312 (1988) (noting that "in July 1861 even radicals who hoped that the war would destroy slavery voted for the Crittenden-Johnson resolutions" which "affirme[ed] that the United States fought with no intention 'of overthrowing or interfering with the rights or established institutions of [the seceded] States' but only . . 'to preserve the Union'”).(quoting Cong. Globe, 37 Cong., 1 Sess., 222-23, 258-62). But I have no interest in pursuing that argument here.

${ }^{543}$ DANIEL J. ElaZAR, EXPLORING FEDERALISM 192 (1987). 
A federal political culture may, however, require one to emphasize one loyalty over the other in particular situations. The Federalist theory of competing loyalties facilitates "disloyalty" against one or the other level of government by giving citizens a second option when one government adopts policies they find repugnant. As Dean Rubin and Professor Feeley recognize, "[f]ederalism ... serves as a means of modulating, or varying, political identity"; it provides individuals "with opportunities to divide loyalty and rechannel action." ${ }^{544}$ Alexander Hamilton made this clear in Federalist 28:

Power being almost always the rival of power, the general government will at all times stand ready to check the usurpations of the state governments, and these will have the same disposition towards the general government. The people, by throwing themselves into either scale, will infallibly make it preponderate. If their rights are invaded by either, they can make use of the other as the instrument of redress. ${ }^{545}$

The balance of popular loyalty in a federal political culture is not fixed, but fluid, shifting to one level of government or the other in response to the behavior of each. American federalism should thus not seek to duplicate Colonel Lee's notion of "my state, right or wrong," but rather simply to maintain the States as sufficiently plausible objects of loyalty that, in the event of misbehavior at the center, they can attract the allegiance of a dissatisfied populace.

I want to use Lee's example to illustrate the phenomenon of putting one's state first, not to advocate taking that decision to the lengths that Lee did. One need not recognize a right to secede from the national polity in order to be serious about constitutional limits on central authority within that polity. ${ }^{546}$ One might argue for constitutional power to defy the disfavored sovereign's pronouncements, as an earlier generation of Virginians did in response to the Alien and Sedition Acts and as some states and localities opposed to the USA PATRIOT Act have asserted a right to do in the

\footnotetext{
${ }^{544}$ FEELEY \& RUBIN, supra note 14 , at 15 . As Rubin and Feeley point out, federalism is not the only way to modulate identity in this way: "[t]he individual could become attached to a religion, a clan, a cultural movement, or a vocation." Id.

${ }^{545}$ Federalist No. 28, at 181 (Alexander Hamilton) (Clinton Rossiter ed., 1961) (italics added).

${ }^{546}$ For a thoughtful discussion of the constitutional legitimacy of secession, see Sanford Levinson, Perpetual Union, Free Love, and Secession: On the Limits to the Consent of the Governed, 39 Tulsa L. ReV. 457 (2003).
} 
present day. And there are plenty of instances in which one may put a state first within the limits imposed by binding national law, as Colorado and Washington officials did by legislating a permissive state policy on marijuana without purporting to interfere with the enforcement of federal law. One might simply choose to direct one's political energies to reform at the state level, as early abolitionists and Progressives did, in hopes that such reforms will eventually be able to "go national."

What impact would a revived emphasis on state identity have on national allegiances? Many have assumed that such identities must inevitably trade off with one another, as Colonel Lee's example suggests. Observers of contemporary Europe, for example, worry that strong national identities have undermined efforts to strengthen EU institutions. ${ }^{547}$ This is not the only possibility, however. Edmund Burke suggested much earlier that " $[\mathrm{t}] \mathrm{o}$ be attached to the subdivision, to love the little platoon we belong to in society, is the first principle (the germ as it were) of public affections. It is the first link in the series by which we proceed toward a love to our country and to mankind." 548 For Burke, loyalty is cumulative. We first learn loyalty in our families, which prepare us to develop attachments to a school, a church congregation, or a town. These attachments then extend outward to state and nation - and ultimately, if Burke is right, to humanity generally. $^{549}$

Similarly, David Brooks - a modern-day Burkean — has emphasized "the tremendous power of particularity. If your identity is formed by hard boundaries, if you come from a specific place ... you are going to have more depth and definition than you are if you grew up in the far-flung networks of pluralism and eclecticism, surfing from

${ }^{547}$ See, e.g., Amitai Etzioni, EU: Closing the Community Deficit, 43 InTERECONOMICs 324, 325 (2008) (observing that “'Euroskepticism' . . seems to be on the rise and is reported to be tied to national identities that have become both stronger and more exclusive").

${ }^{548}$ Edmund Burke, Reflections on the Revolution in France, 41 (J. G. A. Pocock ed., Hackett Pub. Co. 1987) (1790).

${ }^{549}$ See also Jacob T. Levy, States of the Same Nature: Bounded Variation in Subfederal Constitutionalism, in New Frontiers of State Constitutional Law: Dual Enforcement of Norms 25, 29 (James A. Gardner \& Jim Rossi, eds. 2010) (suggesting that the founders thought that "republicanism at the sate level could provide an appropriate civic education for republicanism at the federal level"); Philip Selznick, Afterword: Federalism and Community, in DiLEMMAS OF SCALE, supra note 503, 355, 366 (observing that "particular attachments are not only compatible with, but can preserve and strengthen, more comprehensive unities"). 
one spot to the next, sampling one style then the next, your identity formed by soft boundaries, or none at all." ${ }^{550}$ Not altogether surprisingly, Mr. Brooks was writing about Bruce Springsteen's New Jersey, seeking to explain "why younger rock bands can't fill stadiums year after year, while the more geographically defined older bands like U2, Springsteen and the Beach Boys can."

This view suggests that state identity may provide training for national citizenship, and it dovetails with anecdotal evidence that sentiments of national patriotism may be strongest in parts of the country where state and local identities are also stronger. As James McPherson as observed, "[t]he South is today one of the most patriotic regions of America; many who profess a love for the Confederate flag would be among the first to leap to the defence of the American flag and the civic nationalism it represents. $" 552$ Likewise, some theorists of European integration have viewed a commitment to panEuropean ideals as complementary to, not inconsistent with, strong attachments to the Member States. ${ }^{553}$ Looking around the world, we see examples of countries where national and subnational identities coexist, with each level of identity serving important functions for their citizens. David Miller observes, for example, that "Belgium, Canada,

${ }^{550}$ David Brooks, The Power of Particularity, N.Y. TIMES, June 25, 2012, available at http://www.nytimes.com/2012/06/26/opinion/brooks-the-power-of-the-particular.html?_r=0.

Analogously, advocates of teaching state history argue that its greater particularity, vis-à-vis national history, helps students build the skills needed to analyze a broader range of historical questions. [cite]

${ }^{551} I d$.

${ }^{552}$ MCPHerson, supra note 116, at 73; see also COBB, supra note _, at 325 (noting "the longstanding determination of so many southerners to show their "Americanness" through ostentatious professions of patriotism" and "historically high levels of military participation and enthusiasm for military action").

${ }^{553}$ See Thomas Darnstädt, Jan Puhl, Hans-Jürgen Schlamp, Christoph Schult, \& Helene Zuber, How the EU Can Emerge from the Ashes, SPIEgel OnLINE, Nov. 18, 2011, available at http://www.spiegel.de/international/europe/0,1518,druck-797626,00.html ("For [Erhard] Denninger, one of the leading experts on the German constitution, the notion that European nations only stand a chance of preserving their national identities within a union is old hat. $\mathrm{He}$ cites Hermann Heller, an important constitutional law professor in the Weimar Republic, who, shortly after the catastrophe of World War I, raised the question of "whether the only hope of saving the cultural individualism of the European nations is through a sovereign European federal nation."”). 
and Switzerland work as they do partly because they are not simply multinational, but have cultivated common national identities alongside communal ones, and partly because they have developed institutions (federalism, decentralization) to ensure that each community has its interests protected against incursions by the rest. ${ }^{, 54}$

Or the dynamics may be more complicated still. In Europe, for instance, the rise of European identity has arguably strengthened subnational identity while weakening the national identities caught in between. As Samuel Huntington explains, "[ $t]$ he emergence of a broader supranational identity [in Europe] reinforces the simultaneous narrowing of identities. Scots increasingly think of themselves as Scottish rather than British because they can also think of themselves as European." ${ }^{555}$ Notwithstanding Scotland's ultimate vote not to secede (for now), this development is already having profound consequences for the structure of Great Britain.

Even if subnational loyalties may sometimes undermine support for the center, that may not always be a bad thing. The literature on patriotism and national loyalty is replete with warnings that "[p]atriotism turns out to be a permanent source of moral danger." ${ }^{556}$ As George Fletcher puts it, "[b]lind adherence to any object of loyaltywhether friend, lover, or nation - converts loyalty into idolatry. There is a moral danger in thinking that any concrete person or entity could become the ultimate source of right and wrong." $" 557$

Far from condemning the notion that one might prefer one's state to the nation, our Founders envisioned a world in which our two levels of government would perpetually compete for the loyalty and sympathy of the sovereign People. ${ }^{558}$ As Justice Kennedy observed in Term Limits, "[i]t was the genius of their idea that our citizens would have two political capacities, one state and one federal, each protected from

\footnotetext{
${ }^{554}$ MiLLER, supra note 94, at 96.

${ }^{555}$ Huntington, supra note _, at 14; see also id. (noting that "[t]his is equally true for Lombards, Catalonians, and others").

${ }^{556}$ Alasdair MacIntyre, Is Patriotism a Virtue? The Lindley Lecture, University of Kansas, reprinted in Political Thought (eds Rosen and Wolff) (OUP, Oxford, 1999).

${ }^{557}$ Fletcher, supra note 161 , at 6.

${ }^{558}$ See generally Todd E. Pettys, Competing for the People's Affection: Federalism's Forgotten Marketplace, 56 VAND. L. REV. 329 (2003).
} 
incursion by the other. The resulting Constitution . . . establish[ed] two orders of government, each with its own direct relationship, its own privity, its own set of mutual rights and obligations to the people who sustain it and are governed by it." ${ }^{, 559}$ Each citizen, then, is at least potentially torn - as Colonel Lee was-between his loyalty to the Nation and to the State. "[T]he core thought," as Jacob Levy explains, "is that authority can be safely vested in the central government in part because, and perhaps just to the degree that, the people are inclined to be loyal and attached to their states rather than to the center." $" 560$

State identities are not, of course, the only alternative available to individuals dissatisfied with national policy. As Anthony Smith points out, "the self is composed of multiple identities and roles - familial, territorial, class, religious, ethnic and gender." 561 Certainly one can point to instances of popular mobilization around each of these different identities, from union activism for workers' rights to religious opposition to abortion or unjust wars to Mothers Against Drunk Driving. But my point is not that states offer the only alternative; rather, they represent one of several classes of intermediary institutions that stand between the individual and the national state. ${ }^{562}$ As Tocqueville suggested, the Republic will generally benefit from having a wide variety of such institutions as part of a robust civil society. ${ }^{563}$

The American states may be an attractive form of intermediary institution precisely because they do not have volks. As Vicki Jackson points out, "because state lines do not necessarily correspond to lines of ethnic, racial, or religious identity, which can be more deeply divisive, maintaining the significance of state governments may help foster civic identities that overlap with more deeply felt identities in ways that create

\footnotetext{
${ }^{559}$ U.S. Term Limits, Inc. v. Thornton, 514 U.S. 779, 838 (1995) (Kennedy, J., concurring).

${ }^{560}$ Levy, supra note 23 , at 465.

${ }^{561}$ SMITH, supra note 94, at 4; see also FEELEY \& RUBIN, supra note 14, at 11.

${ }^{562}$ See generally John O. McGinnis, Reviving Tocqueville's America: The Rehnquist Court's Jurisprudence of Social Discovery, 90 CAL. L. REV. 485 (2002); J. Harvie Wilkinson III, Is There a Distinctive Conservative Jurisprudence? 73 U. Colo. L. ReV. 1383, 1384 (2002); see also Ernest A. Young, The Conservative Case for Federalism, 74 GeO. WASH. L. REV. 874, 883-86 (2006).

${ }^{563}$ See AleXis De ToCQueville, Democracy IN AMERICA _.
} 
cross-cutting allegiances." 564 She concludes that "[t]hese allegiances, in turn, could increase the prospects for tolerance and accommodation in the face of profound disagreements. ${ }^{~} 565$ States also derive certain advantages from their status as governments. Unlike many religious bodies and nongovernmental organizations, states have welldeveloped mechanisms of democratic accountability, and they are bound to respect the constitutional rights of their members. It may be considerably more difficult for individuals to hold the Roman Catholic Church or the Sierra Club accountable for their actions and positions.

Daniel Elazar has written that "there is no federal system that is commonly viewed as successful . . . whose people do not think federal, that does not have a federal political culture and a strong will to use federal principles and arrangements." 566 This federal culture requires meaningful attachments and loyalties to both the center and the subnational units. If that is true, then a revival of state identity may be attractive under modern conditions. The more difficult questions concern how that is to be done. Those questions, however, must await a companion essay to this one. It will be enough for now simply to suggest that reports of state identity's death are greatly exaggerated, and that that is good news.

\section{Conclusion}

In the preface to his collection of essays on each of the several states, Matt Weiland asks, "who hasn't marveled at the richness of lives we don't know?"567 The answer may be, not enough of us. Academics at national law schools, and lawyers in national law firms, think we know that Americans' lives are becoming increasingly homogeneous. As Mr. Weiland puts it, "it's very easy ... to feel as though the whole

\footnotetext{
${ }^{564}$ Jackson, supra note 154, at 2221; see also Mark C. Gordon, Differing Paradigms, Similar Flaws: Constructing a New Approach to Federalism in Congress and the Court, YALE L. \& POL'Y REV. \& YALE J. REG. (Symposium Issue) 187, 217-18 (1996) ("America has managed to maintain stability even in an era of robust individual rights precisely because the divisions that define our political structure (i.e., states) do not coincide with the divisions that define our social and cultural structure (such as racial and ethnic groups and economic and national interests)."); SHAPIRO, supra note 142 , at $123-24$.

${ }^{565}$ Jackson, supra note 154, at 2221-22.

${ }^{566}$ DANIEl J. ElAZAR, EXPLORING FEDERALISM 192 (1987).

${ }^{567}$ Matt Weiland, Preface, in STATE By State, supra note 3, at xiii.
} 
country's becoming more homogeneous - it is! There's no doubt about that." But the glass, while no longer full, is also not empty: “[I]t's important to recognize how resilient independent stores, independent magazines, local culture, accents, cults, and private forms of religion are. . . . [I]f you actually look around it's a wonder the country isn't even more homogeneous than it is." 568 The "varied carols" that Walt Whitman heard American singing in the mid-nineteenth century are still audible today. ${ }^{569}$

In this essay, I have endeavored to collect evidence that the American states remain more diverse and distinctive than people sometimes think, and that Americans continue to identify - to at least some extent—with their states. I have also suggested that this distinctiveness and sense of identity is crucial to the health of our federal system. That system relies not only on exit and voice, but also loyalty. The attachment of citizens to their states as political communities fuels debate and innovation, and it drives both the political and administrative safeguards of federalism. Like any other institution, federalism will endure only if people have a reason to care about it.

The general persistence of state distinctiveness and attachments should be reassuring, whether or not one identifies strongly with a state. A decline of those sentiments would threaten the stability of a system that produces many other virtues. Although federalism may often arise, historically speaking, out of profound cultural difference, the need for federalism as a constraint on central power will almost certainly survive the death of those differences. If that is right, then both politicians and scholars need to turn their attention to ways in which the divided loyalties of Americans-so integral to the Founders' plan - may be preserved. A full exploration of the means by which this might be done must await a follow-on project to this one, but the short answer is that the "sovereignty" of the States ultimately depends on their "autonomy"- that is, on their continuing ability to make meaningful legislative choices on behalf of their citizens.

\footnotetext{
${ }^{568}$ Matt Weiland, in Zach Baron, Interview: State by State's Matt Weiland, Village Voice, Dec. 23, 2008, available at http://blogs.villagevoice.com/music/2008/12/interview_state.php (visited March 18, 2011).

569 Walt Whitman, I Hear America Singing, in Walt Whitman, Leaves of Grass: Comprehensive Reader's Edition _ (Harold W. Blodgett \& Sculley Bradley, eds., 1965) (1867).
} 
Constitutional law can protect aspects of that autonomy, by limiting national power in extreme cases and by influencing the interpretation and implementation of federal statutory schemes. Much will depend, however, on the efforts of the states themselves. As Madison foresaw, the best way for states to maintain their role in our federal system is by being worthy of trust - by developing innovative and successful programs to meet the needs and preferences of their citizens, by respecting their citizens' rights and sense of fairness, and by cultivating, preserving, and teaching the cultural and political heritage that makes each state unique. If they succeed in this, then perhaps New Jersey will no longer have citizens who are "Born to Run." 